Gláucia Nize Martins Santos

\title{
E-learning em Diagnóstico Bucal
}




\section{Gláucia Nize Martins Santos}

\section{E-learning em Diagnóstico Bucal}

Dissertação apresentada como requisito parcial para a obtenção do Título de Mestre em Ciências da Saúde pelo Programa de PósGraduação em Ciências da Saúde da Universidade de Brasília.

Orientadora: Profa ${ }^{\mathrm{a}}$. Dra. Nilce Santos de Melo

Brasília

2016 


\section{GLÁUCIA NIZE MARTINS SANTOS}

\section{E-LEARNING EM DIAGNÓSTICO BUCAL}

Dissertação apresentada como requisito parcial para a obtenção do título de Mestre em Ciências da Saúde pelo Programa de Pós-Graduação em Ciências da Saúde da Universidade de Brasília.

Aprovado em 29 de novembro de 2016.

\section{BANCA EXAMINADORA}

Prof $\stackrel{a}{D} r^{a}$ Nilce Santos de Melo - presidente Universidade de Brasília

Prof ${ }^{\mathrm{a}}$ Dra Nara Maria Pimentel Universidade de Brasília

Prof Dr Rubens Spin-Neto Universidade de Aarhus, Dinamarca

Prof Dr Cleomar Donizeth Rodrigues - suplente Faculdades Integradas da União Educacional do Planalto Central 
Dedico este trabalho à minha família, pela força, incentivo e apoio incondicionais. 


\section{AGRADECIMENTOS}

Agradeço primeiramente a Deus, que em toda a sua glória, permitiu a realização desse trabalho. "O princípio da sabedoria é o desejo autêntico de instrução, e a preocupação pela instrução é o amor... Portanto, o desejo pela sabedoria conduz ao reino." Livro da Sabedoria, 6: 12-20.

À minha super irmã, Graci, pela sua extrema criatividade e empenho, pelo seu companheirismo e amor incondicionais, que mesmo nas horas mais difíceis de nossa família, abriu mão de seus próprios sonhos para que eu pudesse levar adiante esse trabalho, cuidando de todos nós. Saiba que você é um grande exemplo de coragem, dedicação, força e amor para mim.

À minha amada mãe, Nilce, que com muito trabalho colocou a nossa educação moral e intelectual como prioridade. Extraordinária educadora, nos ensinou a ter fé, respeito, discernimento, sabedoria, bom-senso, generosidade e amor pelo próximo. Excelente professora, acompanhou de perto desde a formação das primeiras letras no início de nossa alfabetização até a supervisão desse trabalho. Mãe, serei eternamente grata ao legado educacional que você me proporcionou, a melhor herança que uma filha pode receber... muito obrigada!

Ao meu querido pai, Gildo, amoroso, que soube levar com leveza, coragem e bom humor os difíceis problemas que a vida trouxe, que sempre admirou minha dedicação aos estudos e que repetidamente ouviu com ouvidos carinhosos as minhas angústias e anseios, muito obrigada! A morte é apenas uma separação física temporária...Estamos juntos em alma e amor, e brevemente nos reencontraremos!

Aos meus avós, Rosalvo e Elza, de quem tive a honra de herdar grandes ensinamentos para a vida e para boa convivência.

À tia Naná e tio Adão, que sempre incentivaram os nossos estudos e são exemplos, em minha família, do poder transformador da educação.

À minha orientadora Dra Nilce Santos de Melo, que me presenteou com essa proposta de trabalho e, com muita inteligência e sabedoria, sugeriu todas as ferramentas utilizadas para o desenvolvimento dessa pesquisa. Caminhando em um universo bastante diverso do que está habituada a atuar, ainda assim soube levar a orientação ao extremo do conhecimento. Obrigada pelos ensinamentos e 
principalmente por sempre me mostrar que o caminho não precisa ser perfeito, mas sim que podemos extrair o melhor dele.

Aos professores Dr André Leite e Dr Paulo Tadeu, que detém a árdua missão de motivar e ensinar os alunos de graduação da Universidade de Brasília e realizam seu trabalho de maneira criativa e inspiradora. Obrigada por dividir comigo suas experiências de ensino e, também, por terem me dado a oportunidade de atuarmos juntos nessa grande missão.

Às professoras Dra Eliete Guerra e Dra Graziela De Luca Canto, pelo conhecimento, compreensão, amizade e auxílio no desenvolvimento da revisão sistemática, meu eterno agradecimento.

A graduanda de Odontologia Brendda Juliana, que participou ativamente do projeto, com afinco e dedicação! Que nossa parceria nesse projeto seja inspiração para que sua trajetória nos caminhos da ciência prospere!

Ao amigo Helbert, que foi o principal incentivador para que a ideia saísse do papel e se tornasse realidade. Obrigada pelos conselhos, pelas risadas e pela amizade! Além de ser um grande profissional, é uma pessoa inigualável pela sua bondade, paciência, solidariedade e generosidade.

Ao Dr Cleomar, que me abriu os caminhos para a prática da Radiologia Odontológica, que com muita paciência, competência e carinho soube me transmitir o conhecimento necessário para o pleno desempenho da profissão que escolhi. A minha admiração e gratidão se refletem diariamente no nosso trabalho!

Às companheiras de pós-graduação Fernanda, Elisa e Lorena. Amigas, vocês tornaram o caminho muito mais fácil e divertido!

Ao Dr Everton, pelo grande auxílio no desenvolvimento da parte tecnológica do trabalho. Obrigada por ter acreditado que daria certo!

Aos alunos do curso de Odontologia da Universidade de Brasília, muito obrigada. 
"O essencial, com efeito, na educação, não é a doutrina ensinada, é o despertar."

(Ernest Renan) 


\section{RESUMO}

A popularização das Tecnologias de Informação e Comunicação e da Internet vem provocando transformações sobretudo nos modelos educacionais tradicionais, obrigando aqueles que estão à frente das instituições de ensino a repensar a sala de aula e a didática dos professores. Porém, ter uma infinidade de informações disponíveis de fácil acesso não pressupõe a capacidade de transformá-las em conhecimento. Isso significa que o processo de aprendizagem na era digital está vinculado ao processamento da informação do ambiente virtual em conhecimento. Para tanto, o presente trabalho visou avaliar o uso da forma computacional de ensino a distância, e-learning, na disciplina de Diagnóstico Bucal, como ferramenta de ensino para os alunos de graduação em Odontologia. A pesquisa compõe-se de quatro artigos científicos que abrangem uma revisão sistemática sobre a efetividade do elearning no ensino de Radiologia Oral, a descrição do desenvolvimento da Realidade Aumentada a partir de imagens tomográficas, a apresentação de um projeto piloto sobre o uso da plataforma Moodle na área de Radiologia Oral e, por fim, o relato da experiência da utilização do WhatsApp como ferramenta de apoio ao ensino presencial em Radiologia Oral. Evidências sugerem que o e-learning é pelo menos tão eficiente quanto o método tradicional de ensino e os alunos demonstram atitudes positivas em relação à sua implementação. Foi observado, no entanto, que a participação dos estudantes nos módulos online foi baixa, e que há vários fatores que interferem nesse processo educacional. Em conclusão, é necessário dar sentido ao uso da tecnologia, e o maior desafio do professor é despertar no aluno a curiosidade e dar um objetivo evidente ao uso de novas tecnologias no aprendizado.

PALAVRAS-CHAVE: Educação; Odontologia; E-learning; Realidade Aumentada. 


\section{ABSTRACT}

The high popularity of the Internet and Communication and Information Technologies have been changing the traditional educational models, forcing those responsible for the education institutions to rethink about classroom and teachers' pedagogical skills. However, having a great amount of easy access and available information do not suppose ability to turn them into knowledge. It means that the learning path in digital era is directly related to the virtual environment information processed into knowledge. In this context, the present work aimed to evaluate the computational method of distance learning, e-learning, in Oral Diagnosis discipline, as a teaching tool for Dentistry undergraduate students. This research is composed by four original articles which includes a systematic review about the effectiveness of elearning in Oral Radiology, the development of Augmented Reality from tomographic acquisitions, the presentation of a pilot project that provided Oral Radiology contents in Moodle platform and, at last, the report of an experience using WhatsApp as a support tool to the face-to-face Oral Radiology classes. Evidences suggest that elearning is at least as efficient as the traditional method of teaching, and that students have positive attitudes toward its implementation. However, it was observed that the students' participation in the online modules was low, and that there are many factors influencing this educational process. In conclusion, it is necessary to give signification to technology, and the major teacher's challenges are to awaken students' curiosity and purpose a clear objective to the use of new technologies in learning.

KEYWORDS: Education; Dentistry; E-learning; Augmented Reality. 


\section{LISTA DE ABREVIATURAS E SIGLAS}

$\begin{array}{ll}\text { fbx } & \text { filmbox } \\ \text {.jpeg } & \text { joint photographics experts group } \\ \text {.obj } & \text { object file wavefront 3D } \\ \text {.pdf } & \text { portable document format } \\ \text {.stl } & \text { stereolithography } \\ \text { 2D } & \text { Two-Dimensional } \\ \text { 3D } & \text { Three-Dimensional } \\ \text { App } & \text { Application } \\ \text { AVA } & \text { Ambientes Virtuais de Aprendizagem } \\ \text { CAI } & \text { Computer-Assisted Instruction } \\ \text { CAL } & \text { Computer-Assisted Learning } \\ \text { CBCT } & \text { Cone Beam Computed Tomography } \\ \text { CT } & \text { Computed Tomography } \\ \text { DEGD } & \text { Diretoria de Ensino de Graduação a Distância } \\ \text { DICOM } & \text { Digital Imaging and Communications in Medicine } \\ \text { DLO } & \text { Digital Learning Object } \\ \text { DOS } & \text { Disk Operating System } \\ \text { E-learning } & \text { Eletronic learning } \\ \text { FOV } & \text { Field Of View } \\ \text { GA } & \text { Graphic Application } \\ \text { GB } & \text { Gigabyte } \\ \text { LILACS } & \text { Siteratura Latino-Americana e do Caribe em Ciências da } \\ & \end{array}$


L-VIS

LVO

MB

MEC

$\mathrm{MeSH}$

MINORS

M-learning

Moodle

MRI

NMRI

PRISMA

QR code

RA/ AR

RAM memory

ROI

TICs

TRIL

UnB

VR

WWW

$\mathrm{XCP} \circledast$ instrument
Laboratório de Visualização e Interação da Universidade de Brasília

Learning Virtual Object

Megabyte

Ministério da Educação

Medical Subject Headings (sistema de meta-dados médicos)

Methodological Index for Non-Randomized Studies

Mobile-learning

Modular Object Oriented Dynamic Learning Environment

Magnetic Resonance Imaging

Nuclear Magnetic Resonance Imaging

Preferred Reporting Items for Systematic Reviews and Meta-analysis

Quick Response code

Realidade Aumentada/ Augmented Reality

Random Access Memory

Region Of Interest

Tecnologias de Informação e Comunicação

Trierer Inventar zur Lehrevaluation/ educational evaluation questionnaire of Trier University

Universidade de Brasília

Virtual Reality

World Wide Web

dental $x$-ray film positioning device that helps to increase the dimensional accuracy of dental $x$-ray images 


\section{SUMÁRIO}

1. CONSIDERAÇÕES INICIAIS

1.1 Introdução

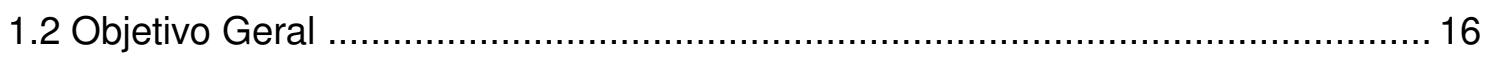

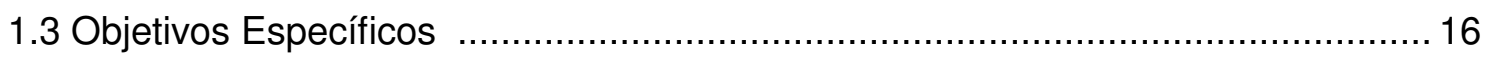

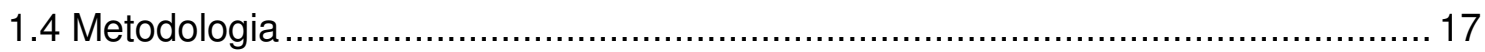

2. Resultados

2.1 Resultados Artigo 1 - Effectiveness of e-learning in Oral Radiology education: a systematic review.

2.2 Resultados Artigo 2 - Augmented reality as a new perspective in Dentistry: development of a complementary tool.

2.3 Resultados Artigo 3 - Metodologias de ensino em Diagnóstico Bucal. Uma experiência na Universidade de Brasília.

2.4 Resultados Artigo 4 - Teaching and learning Oral Radiology via the social medium WhatsApp

3. Discussão GERAL

3.1 Discussão

3.2 Limitações do Estudo .....

3.3 O que aprendemos com esse trabalho

4. CONSIDERAÇÕES FINAIS

4.1 Conclusão

5. REFERÊNCIAS BIBLIOGRÁFICAS

5.1 Referências

6. APÊNDICES

Apêndice 1: Effectiveness of E-learning in Oral Radiology education: a systematic review

Apêndice 2: Augmented reality as a new perspective in dentistry: development of a complementary tool

Apêndice 3: Metodologias de ensino em Diagnóstico Bucal. Uma experiência na Universidade de Brasília

Apêndice 4: Teaching and learning oral radiology via the social medium WhatsApp .. 111

\section{ANEXOS}

Anexo 1: Parecer favorável do Comitê de Ética 128

Anexo 2: Comprovante de aceite de artigo 130

Anexo 3: Comprovante de aceite de artigo 131 
Anexo 4: Termo de Consentimento Livre e Esclarecido para participação via

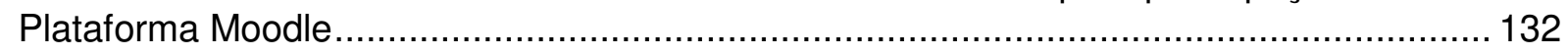

Anexo 5: Termo de Consentimento Livre e Esclarecido para participação via WhatsApp 


\section{CONSIDERAÇÕES INICIAIS}




\subsection{INTRODUÇÃO}

A evolução das Tecnologias de Informação e Comunicação digitais (TICs), caracterizada pelo seu alcance global, integração de todos os meios de comunicação e alta interatividade, tem transformado profundamente a sociedade em todas as suas dimensões, inclusive na educação. Os indivíduos que vêm derrubando ditadores e pedindo justiça nas ruas são os jovens, estudantes dos colégios e das universidades que, em velocidade inimaginável, acessam informações ricas e atualizadas, rompendo o vínculo das instituições que outrora eram as únicas detentoras do

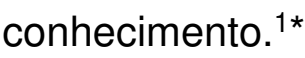

A popularização das TICs e da Internet vem provocando transformações sobretudo nos modelos educacionais tradicionais, obrigando aqueles que estão a frente das instituições de ensino a repensar a sala de aula e a didática dos professores. A escola atual tem uma estrutura irreconhecível para os jovens. O saber tinha como suporte a escrita, os livros. Agora, com a Internet, ele está disponível a todos, em todo lugar. $O$ antigo espaço de concentração do saber se dilui e ninguém precisa se deslocar para aprender algo novo. ${ }^{2}$

Porém, como afirmado por Paiva, Toriani e Lucio $^{3}$ (2012), ter uma infinidade de informações disponíveis de fácil acesso não pressupõe a capacidade de transformá-las em conhecimento. Isso significa que o processo de aprendizagem na era digital está vinculado ao processamento da informação do ambiente virtual em conhecimento.

Apesar da afirmação de Paulo Freire ${ }^{4}$ (1996) ditar que "ensinar não é transferir conhecimento, mas criar as possibilidades para a sua própria produção ou a sua construção", a cultura organizacional do ensino superior continua repetindo o modelo transmissionista, gerando conflitos em sala de aula e lutas pelo poder da informação, resultando em baixo aproveitamento de todo o grupo. ${ }^{5}$

Segundo Gabriel ${ }^{6}$ (2013), é fundamental que os educadores conheçam as características dessas gerações digitais para poderem desenvolver processos educacionais, e salienta que a tecnologia em si não é o diferencial para boas práticas pedagógicas. Portanto, o professor continua sendo imprescindível, desde que

\footnotetext{
*Formatação das Referências Bibliográficas no estilo Vancouver.
} 
consiga, no seu fazer pedagógico, ser parceiro e mediador da construção do conhecimento. $^{7}$

Ruiz et al. ${ }^{8}$ (2006) afirmam que o e-learning se mostra como uma "revolução na educação" na área de saúde. Ganhou popularidade na última década, com uso diverso nas escolas médicas, mais popularmente nas matérias básicas do que nas especialidades clínicas. Muitas universidades e organizações de saúde já estão produzindo materiais altamente confiáveis de e-learning, como simuladores de pacientes virtuais, que em breve estarão em pleno alcance dos professores e estudantes. ${ }^{9,} 10$

Estudantes de Odontologia estão sendo cada vez mais expostos às novas tecnologias de ensino, particularmente àquelas disponibilizadas online, desafiando 0 ensino presencial e a atuação da prática clínica. Diversos estudos sobre desenvolvimento, aplicação e avaliação de e-learning no currículo da Odontologia têm sido realizados, nas mais variadas disciplinas, como ortodontia, anatomia, patologia oral, prótese fixa e removível, dentística, entre outras. Esses trabalhos têm a finalidade de avaliar a percepção, expectativas, performance e resultado do aprendizado dos alunos, a efetividade dos cursos, o desenho e a forma de apresentação dos conteúdos, e as atitudes e opiniões dos professores em relação às tecnologias aplicadas ao ensino. ${ }^{11}$

\subsection{OBJETIVO GERAL}

Avaliar o uso da forma computacional de ensino a distância, e-learning, na área de Diagnóstico Bucal, como ferramenta de ensino para os alunos de graduação em Odontologia. Dentro dessa perspectiva, o foco foi introduzir aos alunos essa ferramenta de aprendizado, bem como verificar seu interesse e atitude relacionados ao e-learning.

\subsection{OBJETIVOS ESPECÍ́FICOS}

A. Elaborar uma revisão sistemática com a finalidade de avaliar a efetividade do e-learning no ensino de Radiologia Oral quando comparada com o método tradicional de ensino. 
B. Desenvolver a tecnologia de Realidade Aumentada voltada para o uso educacional de Radiologia Oral, a partir de exames tomográficos de pacientes.

C. Desenvolver conteúdo instrucional online de Radiologia Oral e o disponibilizar via plataforma Moodle para alunos de graduação, aliado à ferramenta de Realidade Aumentada, a fim de avaliar a atitude dos alunos em relação a essa nova ferramenta.

D. Desenvolver e disponibilizar material de Radiologia Oral via mídia social WhatsApp, com o intuito de verificar a aceitação, por parte dos alunos, do uso desse aplicativo em educação.

\subsection{METOdOLOGIA}

Com o objetivo de avaliar o uso de tecnologia no ensino de Diagnóstico Bucal, o presente trabalho contemplou quatro objetivos específicos em forma de artigos científicos, disponíveis nos apêndices de 1 a 4 da presente dissertação. O primeiro objetivo resultou em uma revisão sistemática, que buscou avaliar a efetividade do $e$ learning no ensino de Radiologia Oral, quando comparada ao método tradicional de ensino em sala de aula. A revisão sistemática pode ser definida como um sumário de evidências decorrentes de estudos primários organizados para responder uma questão específica de pesquisa. Ao utilizar um processo de revisão de literatura abrangente, imparcial e reprodutível, possibilita a localização, avaliação e síntese de evidências de estudos científicos para obter uma visão geral e confiável da estimativa do efeito da intervenção. ${ }^{12}$ As orientações do PRISMA (Preferred Reporting Items for Systematic Reviews and Meta-analysis) foram seguidas, conforme descrito em: http://www.prisma-statement.org/statement.htm, com registro no PROSPERO (www.crd.york.ac.uk/PROSPERO/). A revisão sistemática "Effectiveness of elearning in oral radiology education: a systematic review" está apresentada no apêndice 1.

O segundo artigo descreve o desenvolvimento da ferramenta de Realidade Aumentada (RA) a partir de aquisições de tomografias computadorizadas, com a finalidade disponibilizar aos alunos um recurso inovador para a visualização, em 
tablets e smartphones, de exames por imagem em terceira dimensão. A tecnologia de RA integra o mundo real a cenas ou objetos virtuais em três dimensões, com a possibilidade de interação em tempo real. Foi desenvolvida com o apoio do Laboratório de Visualização e Interação (L-VIS), do departamento de Engenharia Civil da Universidade de Brasília. $O$ artigo "Augmented reality as a new perspective in dentistry: development of a complementary tool” está descrito no apêndice 2 do presente trabalho.

O terceiro artigo apresenta a experiência de um projeto piloto de educação a distância via plataforma Moodle* de conteúdo complementar de Radiologia Oral, desenvolvido junto ao Departamento de Ensino e Graduação a Distância (DEGD) da Universidade de Brasília, no qual a ferramenta de Realidade Aumentada foi aplicada. O relato, intitulado "Metodologias de ensino em Diagnóstico Bucal. Uma experiência na Universidade de Brasília” encontra-se no apêndice 3.

Por fim, o quarto artigo descreve a experiência do uso da mídia social WhatsApp** como ferramenta de apoio para a assimilação do conteúdo transmitido presencialmente na disciplina Diagnóstico Bucal, da Universidade de Brasília. As mídias sociais são aplicações baseadas em grupos de pessoas interligadas via Internet, que permitem criação e compartilhamento de conteúdos criados pelos usuários. Atualmente, uma das mais populares mídias sociais disponíveis é o WhatsApp, por ser gratuito e compatível com os mais diversos smartphones. O estudo surgiu como uma evolução do modelo anterior via Moodle, na perspectiva de se aproximar dos alunos utilizando uma ferramenta bem conhecida por eles, porém com finalidade educacional. A pesquisa cujo título é "Teaching and learning oral radiology via the social medium WhatsApp" apresenta-se no apêndice 4.

Os trabalhos foram submetidos ao Comitê de Ética da Faculdade de Saúde da Universidade de Brasília e foram aprovados sob o número CAAE 42277115.3.0000.0030, sendo que a revisão sistemática está publicada na edição de setembro do periódico Journal of Dental Education, classificada como A2 no programa QUALIS de Odontologia e 0 artigo “Augmented reality as a new perspective in dentistry: development of a complementary tool" foi aceito pela revista da ABENO, classificada como B2 no programa QUALIS de Odontologia.

\footnotetext{
* Plataforma Moodle, versão 2.7

** Mídia social WhatsApp, versão 2.16 .19
} 
2. Resultados 
2.1 Resultados Artigo 1 - Effectiveness of E-Learning in Oral Radiology EDUCATION: A SYSTEMATIC REVIEW

O trabalho "Effectiveness of e-learning in oral radiology education: a systematic review" (apêndice 1) teve como principal objetivo disponibilizar uma síntese sobre a efetividade do e-learning quando comparado ao método tradicional de ensino em sala de aula.

O e-learning tem sido utilizado no currículo de graduação em Odontologia como ferramenta de suporte ao ensino tradicional. No entanto, a literatura publicada sobre o assunto relacionada ao ensino de Radiologia Oral mostra conclusões diversas. A pesquisa de artigos científicos foi conduzida nas bases de dados LILACS, PubMed, Science Direct, Scopus e Web of Science, bem como na literatura cinzenta. O critério de seleção contemplou casos controle sobre o ensino de Radiologia Oral, que comparassem o e-learning a qualquer método de ensino tradicional em sala de aula.

A efetividade foi mensurada utilizando três parâmetros do modelo de avaliação de Kirkpatrick: atitude dos alunos em relação ao e-learning, ganho de conhecimento e performance nos procedimentos práticos. Já a análise qualitativa foi realizada de acordo com as ferramentas de risco de viés da Cochrane, para estudos randomizados e MINORS para estudos não-randomizados.

Dos onze artigos que se encaixaram nos critérios de inclusão, dez reportaram atitude positiva dos alunos em relação ao e-learning. No entanto, o resultado para o ganho de conhecimento foi bastante diverso dentre os oito estudos que contemplaram esse parâmetro, sendo que não houve diferença estatisticamente significante em quatro deles, em dois o ganho foi bastante expressivo e em dois o ganho foi pequeno. Ainda, apenas dois estudos examinaram a performance dos alunos em procedimentos práticos, e mostraram resultados contrastantes.

Portanto, evidências sugerem que o e-learning é pelo menos tão eficiente quanto o método tradicional de ensino. Além disso, os alunos demonstraram atitudes positivas em relação ao uso do e-learning. 


\title{
2.2 Resultados ARTIgo 2 - Augmented REALity AS A NEW PERSPECTIVE IN DENTISTRY: DEVELOPMENT OF A COMPLEMENTARY TOOL
}

\begin{abstract}
O propósito do trabalho seguinte, intitulado "Augmented Reality as a new perspective in Dentistry: development of a complementary tool" (apêndice 2), foi apresentar e descrever o desenvolvimento de uma ferramenta moderna e interativa de Realidade Aumentada (RA) para visualização de modelos tridimensionais em dispositivos móveis, construídos a partir de aquisições de imagens volumétricas de tomografias computadorizadas de pacientes.

A RA foi desenvolvida correlacionando tomografias e softwares livres, conforme a Figura 1, na seguinte sequência: (1) Imagem tomográfica adquirida, isto é, imagens multiplanares que podem ser visualizadas como renderizações em 3D e são a base para a construção das superfícies poligonais de estruturas anatômicas específicas de interesse. (2). Criação dos modelos volumétricos, passo no qual os modelos tridimensionais podem ser salvos e exportados como uma malha poligonal 3D no formato .stl. (3) Simplificação do modelo, necessária para que a matriz poligonal seja simplificada e o peso em megabytes dos modelos reduzido e (4) Construção do projeto de Realidade Aumentada. Assim que tais procedimentos estejam prontos, o projeto pode ser salvo e visualizado em dispositivos móveis.
\end{abstract}




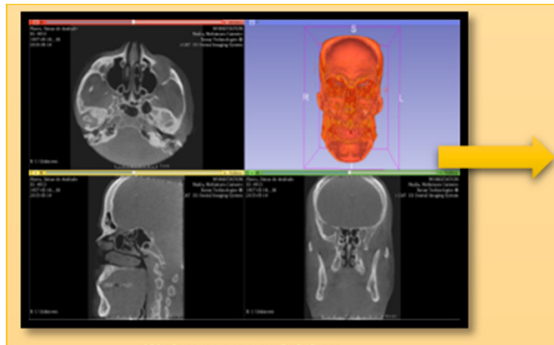

(1) image acquisition

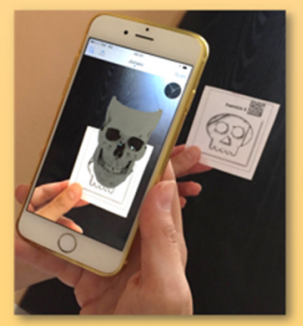

(5) AR visualization in Junaio app

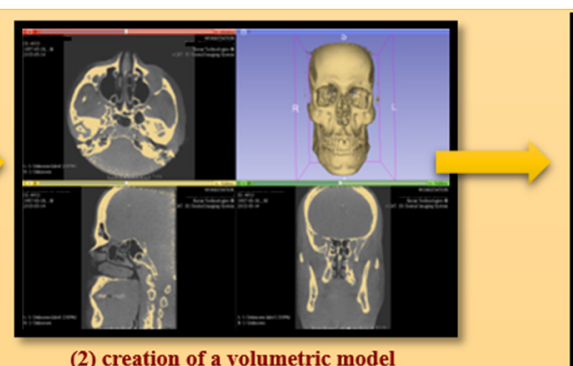

(2) creation of a volumetric model from the yellow label map

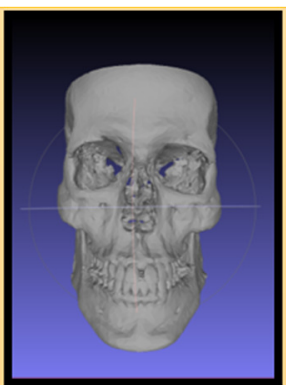

(3) model simplification
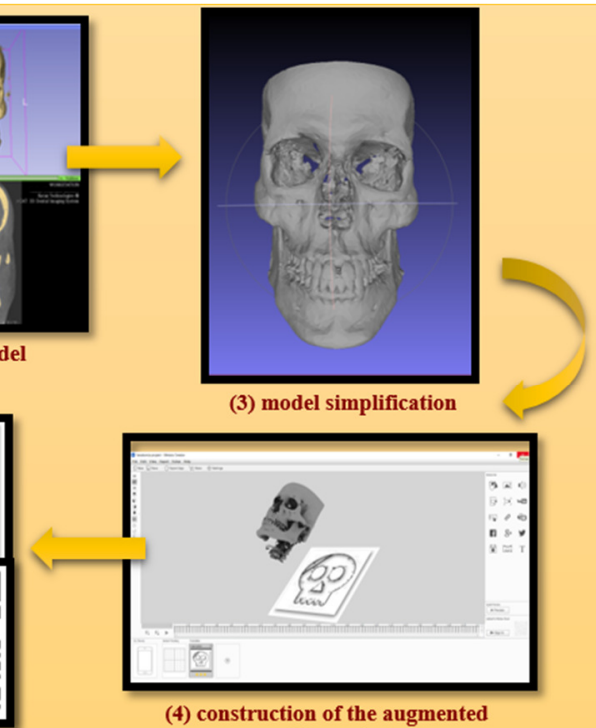

(4) construction of the augmented reality project

Figura 1. (1) Imagem tomográfica adquirida em feixe cônico, sendo visualizada no software leitor DICOM Slicer 3D. (2) No Slicer 3D, o modelo tridimensional é criado, salvo e exportado como uma malha poligonal em formato .stl (3) Na fase de simplificação, o modelo tem redução em megabytes, enquanto a qualidade é mantida, no software MeshLab. (4) A construção do projeto de Realidade Aumentada foi feita no software Metaio Creator. (5) Visualização da RA no aplicativo JUNAIO.

O modelo volumétrico originado de uma aquisição de tomografia computadorizada pode ser disponibilizado em qualquer dispositivo que leia 0 marcador correspondente, por meio de aplicativo específico. Essa tecnologia é capaz de facilitar a visualização dos modelos tomográficos, oferecendo localização precisa de estruturas e anormalidades, tais como dentes supranumerários, fraturas ósseas e assimetrias. Ainda, os modelos podem ser salvos para posterior visualização por múltiplos usuários. Em nosso trabalho, a RA foi desenvolvida no software com versão livre Metaio Creator e o aplicativo de dispositivos móveis capaz de ler os marcadores para visualização dos modelos foi o JUNAIO. Porém, tanto o software Metaio Creator e quanto o aplicativo JUNAIO foram comprados pela Apple em maio de 2015, que os retirou do mercado em 2016. Existem outros softwares capazes de realizar essa mesma função, como o Augmented ou Wikitude, no entanto, não são livres.

A RA é uma nova perspectiva em Odontologia, apesar de estar ainda em fase inicial. Pode ser desenvolvida integrando múltiplas tecnologias e apresenta grande 
potencial para auxiliar o ensino e o aprendizado, e melhorar a forma como os modelos tridimensionais dos exames radiológicos são vistos.

\subsection{Resultados Artigo 3 - Metodologias de ensino em Diagnóstico Bucal. UMA EXPERIÊNCIA NA UNIVERSIDADE DE BRASÍLIA}

A pesquisa "Metodologias de Ensino em Diagnóstico Bucal. Uma experiência na Universidade de Brasília" (apêndice 3) visou avaliar o uso da forma computacional de ensino a distância, e-learning, como ferramenta de ensino para os alunos de graduação em Odontologia, como um projeto piloto.

Os participantes foram os alunos do quarto semestre do curso de Odontologia da Universidade de Brasília, matriculados na disciplina de Diagnóstico Bucal, no segundo semestre de 2015. Paralelamente às aulas presenciais, conteúdos sobre Princípios de Interpretação Radiográfica, alguns associados a ferramenta de RA, foram disponibilizados aos estudantes ao longo do semestre letivo, via plataforma Moodle, como material complementar de estudo, não relacionado ao assunto trabalhado em sala de aula no mesmo período. O material instrucional online foi oferecido a todos os alunos da disciplina de Diagnóstico Bucal, sob aceitação voluntária e sem valor na menção final. Dos 26 estudantes matriculados na disciplina presencial, 25 aceitaram participar da pesquisa. No entanto, dos 25 voluntários, apenas dois concluíram os conteúdos via Moodle.

A partir desse resultado, vários pontos de discussão foram abertos a fim de considerar os diversos aspectos que influenciam o uso da forma computacional de ensino, abrangendo tanto a realidade enfrentada pelo professor quanto a aceitabilidade dos alunos. A discussão completa encontra-se no apêndice 3.

\subsection{Resultados Artigo 4 - Teaching and learning Oral Radiology Via the SOCIAL MEDIUM WHATSAPP}

Tendo em vista a baixa adesão dos alunos no uso do Moodle, a mídia social WhatsApp foi escolhida para avaliar a atitude dos alunos de Odontologia da 
Universidade de Brasília em relação ao e-learning em Diagnóstico Bucal. A facilidade de as mídias sociais serem acessadas por qualquer dispositivo móvel, bem como o aumento do tempo que os estudantes passam utilizando redes sociais justificaram escolher o WhatsApp para o presente trabalho, já que ele é o mais popular aplicativo de trocas de mensagens no mundo.

$O$ artigo "Teaching and learning oral Radiology via the social medium WhatsApp" (apêndice 4) teve como um dos objetivos introduzir o WhatsApp como ferramenta de ensino no curso de Radiologia Oral. Quizzes compostos por questões de múltipla escolha e imagens tomográficas e radiográficas de casos clínicos reais foram disponibilizados no grupo social semanalmente, durante 14 semanas. Outro objetivo foi avaliar a atitude dos alunos em relação ao uso de mídia social com a finalidade educativa, por meio de questionário de satisfação aplicado ao final do semestre.

Todos os 30 alunos matriculados na disciplina presencial de Diagnóstico Bucal ofertada no primeiro semestre de 2016 aceitaram participar voluntariamente do grupo de celular, sem aumento de nota ou crédito, sendo que destes, 28 postaram pelo menos em dois quizzes. Foram contabilizados um total de 372 comentários, dentre respostas às questões de múltipla escolha, dúvidas, discussões em grupo, postagem de casos e propagandas de outros cursos.

O questionário de satisfação foi respondido por 25 alunos, e mostrou que a maioria gostou da experiência, principalmente por terem um professor online disponível e de fácil acesso. Os participantes apontaram os quizzes como didáticos, porém difíceis. Apreciaram a discussão em grupo e a consideraram útil para o aumento do aprendizado. Quando questionados se o método de ensino via WhatsApp era eficiente, a resposta foi bastante diversa. Maiores detalhes estão descritos no apêndice 4 . 
3. DISCUSSÃo GERAL 


\subsection{DISCUSSÃO}

Aparelhos portáteis digitais, com programas e aplicativos que possibilitam conexões e comunicação interativa através da Internet, reduziram o espaço e o tempo entre seus usuários, reconfigurando as relações com as instituições detentoras da informação, ao permitir o acesso a conteúdos brutos, sem edição, sem intermediários e mais rápido que a mídia tradicional.

Segundo Michel Serres ${ }^{2}$ (2013), se as gerações anteriores baseavam sua cultura nas premissas religiosas e na vivência de seus antepassados, os jovens têm sua formação dada pela mídia e pela publicidade. Nesse sentido, a mídia há muito tempo assumiu a função do ensino.

Silva $^{7}$ (2012) observa que o paradigma da educação é também o da comunicação, ou seja, estamos vivendo uma transformação cultural na sociedade, fruto de mudanças na forma de as pessoas interagirem entre si em face da emergência das novas formas de se comunicar que se ampliaram na cibercultura.

Esta nova geração está fisiologicamente habituada ao virtual: a pesquisa pela Internet e a escrita de mensagens com o polegar ativam outros neurônios que não os ativados pela escuta de aulas e pela escrita em cadernos ${ }^{2}$. Dessa forma, um novo ser humano nasceu desde os anos 1970, com uma nova cabeça e com outra percepção de tempo e de distâncias.

Portanto, Serres ${ }^{2}$ (2013) afirma que antes de ensinar o que quer que seja a alguém, é preciso, no mínimo, conhecer esse alguém. Nesse sentido, torna-se imprescindível que o docente do século XXI utilize, aprenda e se adapte a essa nova lógica, isto é, que exerça função mais mediadora e com isso mais contextualizada a essa cultura discente. Diante disso, existe a necessidade de que os educadores conheçam as características dessas gerações digitais para poderem desenvolver processos educacionais.

É preciso analisar, pensar e refletir sobre como as Tecnologias da Informação e da Comunicação (TICs) estão impactando na geração de conhecimento, como tais recursos podem auxiliar o educador e quais metodologias podem ser criadas a partir 
desse novo contexto, ou seja, pensar sobre os paradigmas educacionais emergentes da revolução digital. ${ }^{6}$

Muitos fatores estão relacionados ao êxito na implementação do e-learning, porém nem todos foram reconhecidos e por isso mais estudos são necessários. Os fatores críticos foram inicialmente propostos por Rockhart ${ }^{13}$ (1979) e se tornaram amplamente utilizados como metodologia para examinar os motivos que afetam a habilidade das instituições na implementação de mudanças. Tais fatores podem ser externos, e são geralmente citados pelos docentes como "falta de tempo", "falta de treinamento" e "baixa infraestrutura" 14-17. Já os fatores internos estão relacionados ao próprio indivíduo, e foram definidos pelas pesquisas de Walker \& Johnson ${ }^{18}$ (2008) e Liaw et al. ${ }^{19}$ (2007) como sendo principalmente a "Percepção de Utilidade" e "Percepção de Efetividade".

Nkenke e colaboradores ${ }^{20}$ (2012) relataram em seu estudo que os alunos que participaram do ensino à distância não conseguiram compreender a relevância prática do conteúdo apresentado, e que esse objetivo deveria ser valorizado quando do desenvolvimento da atividade. Tal aspecto também foi encontrado no artigo "Metodologias de ensino em Diagnóstico Bucal. Uma experiência na Universidade de Brasília" (apêndice 3), no qual a grande maioria dos estudantes, por não verem utilidade para melhora da nota e nem efetividade para estudar para a prova, pois o conteúdo era complementar, não concluíram o e-módulo via Moodle. Inclusive, os próprios alunos relataram manter o formato de estudo focado no desempenho em provas, estudando de véspera, e não primordialmente na retenção do conteúdo. Foi também observado que o professor tem papel motivacional indispensável no processo educativo por e-learning, cabendo a ele repensar a construção do ambiente virtual e a abordagem mais interessante para determinado grupo de alunos. Por isso, maior capacitação e infraestrutura para uso de tecnologia deve ser dispensada ao docente, já que a tecnologia por si só não é capaz de transformar estudantes habituados em receber passivamente os conteúdos em alunos com trajetória autônoma. ${ }^{6}$

Conforme demonstrado pela revisão sistemática "Effectiveness of e-learning in oral radiology education: a systematic review" (apêndice 1), aulas presenciais 
e a distância favorecem alunos com estilos de aprendizado específicos. Nenhum método é melhor ou preferível que o outro, apenas diferentes em suas forças e fraquezas. ${ }^{21,} 22$ Para melhor atender aos mais variados alunos, os cursos deveriam apresentar diversas opções de aprendizado, já que a melhor retenção do conhecimento acontece quando o estilo de ensinar concorda com o estilo de aprendizagem. Portanto, a combinação dos tipos de educação - presencial e a distância com uso de tecnologia, ou blended-learning - pode resultar nos efeitos desejados. ${ }^{23}$ Apesar disso, Nkenke e colaboradores ${ }^{20}$ (2012) apontam que a maioria dos alunos admite não se manter concentrado em nenhuma das opções de ensino, sendo esse o grande desafio motivacional do docente.

De acordo com Dariel et al..$^{24}$ (2012), os professores que não utilizam o elearning não são necessariamente "ludistas" (pessoas que se opõem à industrialização intensa ou a novas tecnologias) ou tecnofóbicos. Como demonstrou em seu estudo, muitos educadores têm sido resistentes a mudar sua metodologia de ensino por não ter um profundo entendimento do porquê e de como, além de não terem incentivo para explorar novas metodologias. Ao passo que a tecnologia tem o potencial de habilitar novas possibilidades no ensino, a dificuldade é combinar essas possibilidades com a visão de ensinar e aprender que os educadores mantêm.

No apêndice 2, a ferramenta de Realidade Aumentada (RA), embora seja uma tecnologia de ponta, se mostrou pouco atrativa aos alunos de Odontologia da Universidade de Brasília. Uma das possibilidades é que a RA não era uma tecnologia difundida no Brasil quando foi por nós ofertada. Atualmente, após o lançamento de jogos para celulares que utilizam RA como plataforma, como o mundialmente popular Pokémon GO, os estudantes possivelmente se interessariam mais.

Em contrapartida, conforme apresentado no trabalho de Martín-Gutiérrez et al. ${ }^{25}$ (2015), a RA foi bem recebida e aumentou o conhecimento de estudantes de Engenharia, que a utilizaram para desenvolver modelos laboratoriais de equipamentos. De modo similar, os autores Di Serio et al. ${ }^{26}$ (2013) demonstraram maior motivação dos alunos de ensino médio ao utilizar a ferramenta de RA ao invés de projeção de slides no aprendizado de Artes Visuais, apesar de a RA ainda não estar bem desenvolvida à época do trabalho. Poucos estudos foram realizados com a 
finalidade de avaliar a satisfação e melhora do desempenho dos alunos que utilizaram a RA, e poucos trabalhos relatam como a ferramenta de RA foi adaptada ao ensino de graduação em Odontologia.

Em relação às inovações adotadas, se pode constatar que a Internet apresentou diferentes momentos ao longo de sua história, mais relacionados à forma como os usuários a utilizam do que propriamente ao avanço da tecnologia. $O$ termo Web 1.0 refere-se ao "mundo novo", à Internet como ela surgiu. Caracteriza-se por apresentar sites de conteúdo estático com pouca interatividade entre os internautas e disponibilidade de diversos diretórios de links. ${ }^{27}$ Notadamente, em um dos estudos apresentados (apêndice 3), a construção do e-módulo online na plataforma Moodle se encaixa nesse modelo, no qual os alunos passivamente recebiam o conteúdo e apenas respondiam os exercícios correspondentes. É fundamental observar que a geração a que se destinou o e-módulo via Moodle já não fazia parte do momento Web 1.0 , e esse pode ser um dos motivos para a baixa adesão ao uso da plataforma.

Nielsen e colaboradores ${ }^{28}$ reportaram que estudantes costumam ignorar tecnologias que aparentam ser muito difíceis de usar ou que necessitem de dispositivos que sejam pesados ou não portáteis. Nesse sentido, a plataforma Moodle não foi bem recebida, uma vez que sua navegação plena somente se dava em computadores e não em tablets ou celulares (gráfico 1).

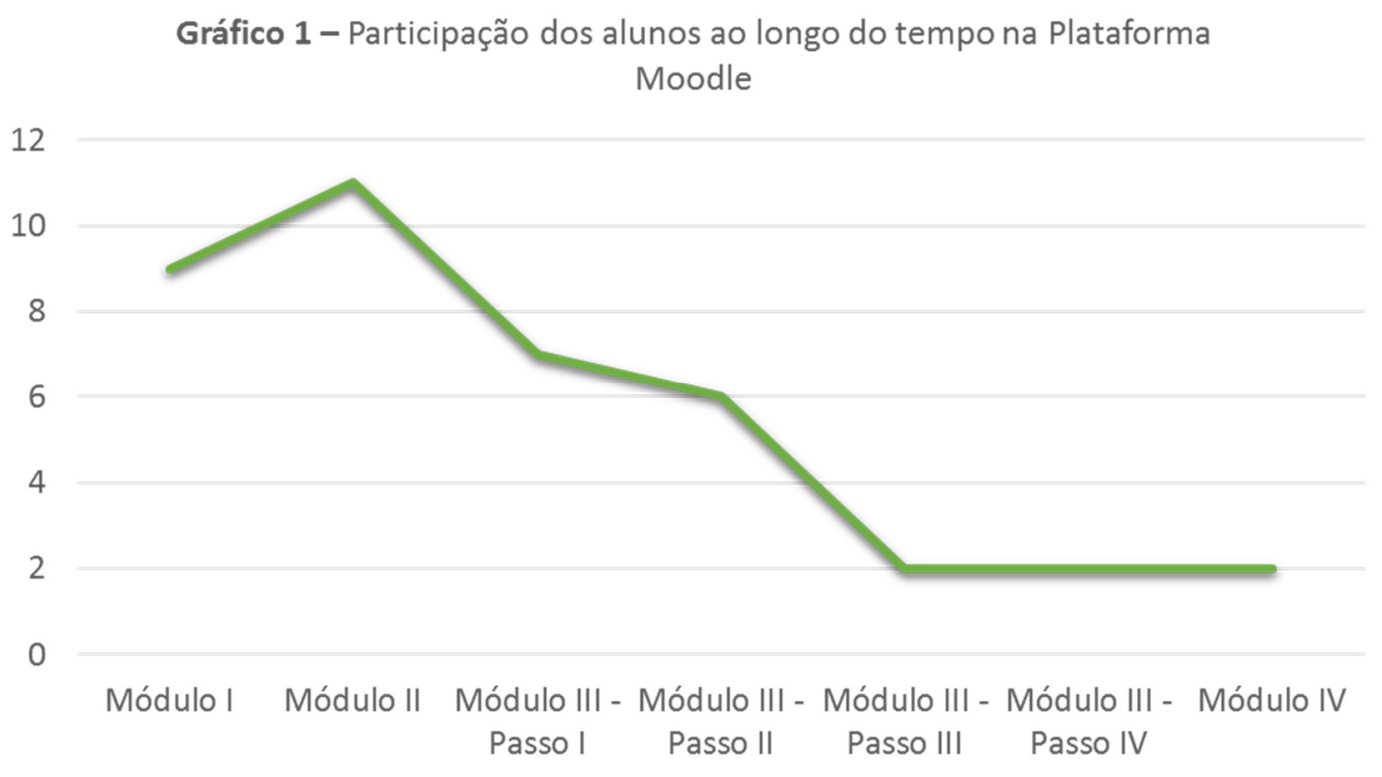


Nielsen et al. ${ }^{28}$ ainda afirmam que se os alunos não receberem uma recompensa imediata pelo seu esforço, eles não clicarão em links nem lerão instruções detalhadas, o que corrobora com o comportamento dos alunos em relação à plataforma Moodle. ${ }^{29}$ Cabe destacar, no entanto, que o Moodle é amplamente utilizado pela Universidade de Brasília. Há quase quatro mil disciplinas ofertadas, nas mais variadas áreas do conhecimento, e quase a totalidade dos graduandos são usuários. Paradoxalmente, conforme demonstrado em nosso estudo, os alunos qualificaram essa plataforma como "boa".

O momento seguinte, designado Web 2.0 ou Web Participativa, se distingue pela revolução dos blogs e chats, das mídias sociais colaborativas, das redes sociais e do conteúdo produzido pelos próprios internautas. Por meio do Youtube, Facebook, Flickr, Picasa, Wikipédia e muitas outras redes sociais, todos passaram a ter voz, e essa voz passou a ser escutada e respeitada. Portanto, as mídias sociais mudaram a relação entre os produtores de conteúdo e o público, tanto por permitir respostas em tempo real quanto por tornar o receptor também produtor. ${ }^{30}$ Dessa forma, a interatividade entre os usuários, com a construção de uma "comunidade virtual", foi o objetivo do estudo "Teaching and learning oral radiology via the social medium WhatsApp" (apêndice 4), no qual foi utilizada a mídia social WhatsApp como ferramenta de apoio ao ensino de Radiologia Oral. Nesse trabalho, constatou-se maior adesão dos alunos (gráfico 2) e satisfação da maioria em trabalhar em grupos, sendo que as postagens dos tutores, associadas à participação dos alunos é que construíram o conhecimento. 


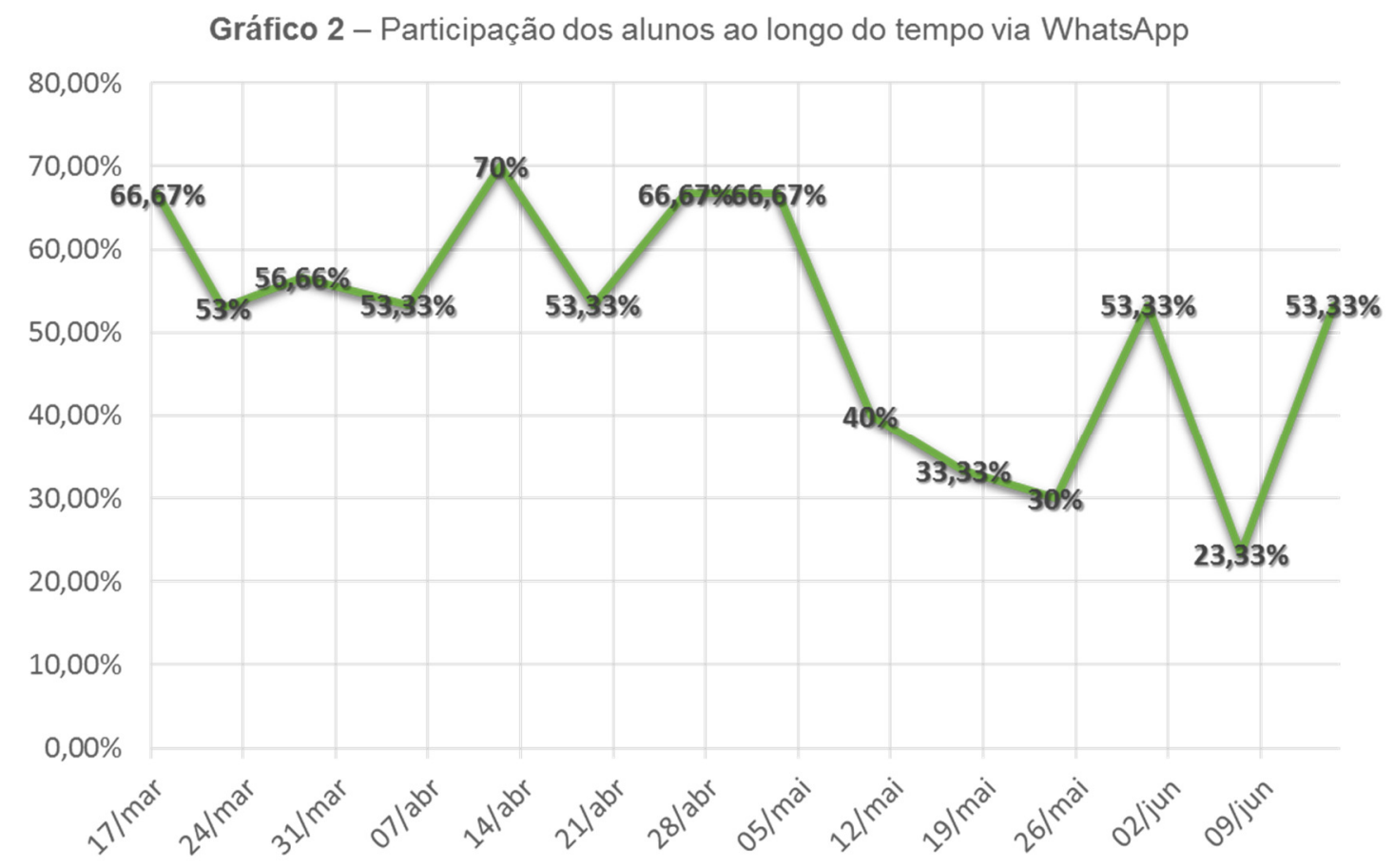

Apesar da maior adesão dos discentes à mídia social voltada para o ensino, observamos em nosso estudo que a participação ainda foi inferior à esperada. Tal fato pode ser consequência da falta de recompensa oferecida, como nota ou crédito, assim como foi observado na experiência utilizando o Moodle (apêndice 3). Isso sugere que os estudantes encaram as TICs como meio de comunicação, informação e diversão, mas não como ferramenta educacional. Uma hipótese para explicar esse comportamento parece ser o perfil dos estudantes de Odontologia da Universidade de Brasília, que ingressam muito jovens na instituição universitária e têm uma trajetória passiva de aprendizado desde o início de sua vida escolar. São, em sua maioria, solteiros, sem filhos, ainda moram com os pais e não trabalham. ${ }^{31}$

Se, por um lado, os estudantes estão bastante familiarizados em utilizar as redes sociais como forma de comunicação em massa, por outro, ainda precisam compreender como se procede a comunicação profissional nessas mídias. ${ }^{32}$ Por exemplo, os alunos precisam ser alertados que julgamentos errôneos cometidos no espaço virtual podem levar a um desfecho permanente e potencialmente prejudicial à carreira profissional. Tornar-se um estudante de Odontologia digitalmente competente 
requer respeito às obrigações profissionais, tal como proteção à privacidade do paciente. ${ }^{33}$

Alan November ${ }^{34}$, líder internacional em educação tecnológica, em seu livro "Who owns the learning? Preparing Students for Success in the Digital Age" (A quem pertence o aprendizado? Preparando estudantes para o sucesso na Era Digital), retrata cinco pontos fundamentais para aumentar o comprometimento dos alunos ao gerenciar seus estudos:

1) quando o aluno detém o aprendizado, ele se torna mais responsável por sua qualidade. Isto é, quando os professores permitem que os estudantes façam suas próprias contribuições às aulas, eles se sentem mais motivados e reflexivos quanto à qualidade do conhecimento a ser trabalhado.

2) quando o aluno tem um propósito com seu conhecimento (por exemplo, contribuir com algum projeto), ele apresenta maior responsabilidade com a qualidade de estudo. Muitos discentes estudam mais quando se sentem desafiados a fazer contribuições importantes em um trabalho ou projeto específico, no âmbito escolar ou fora dele.

3) quando é ofertado ao aluno audiência global, ele se torna mais responsável pela qualidade de seus estudos. Não é surpresa que muitos estudantes se sentem cativados pelo poder da comunicação utilizando seus celulares e mídias sociais. Dessa forma, responsabilidade, motivação e engajamento podem ser majorados em comunidades online de aprendizado e, ao invés de o aluno apresentar seus trabalhos somente para o professor e colegas de sala de aula, podem ser desafiados a compartilhá-los com o mundo via Internet.

4) quando os professores gerenciam seu próprio conhecimento, há uma explosão de ideias. Os professores devem ser incentivados a desenvolver novas estratégias de ensino, e às escolas cabe fornecer mais tempo, infraestrutura e autonomia para que novas ideias de ensino floresçam. 
5) quando os líderes de instituições de ensino mudam seu modelo gerencial, toda a escola se beneficia. As instituições têm incorporado novas tecnologias, como criação de comunidades virtuais e uso de mídias sociais para compartilhamento de informações com seu corpo docente, com os pais de alunos e com outras instituições de ensino e, dessa forma, incentiva que os professores e estudantes se adaptem a essa nova realidade. Os líderes tecnologicamente fluentes podem ser os catalisadores mais importantes para o crescimento das instituições de ensino.

Por fim, Winfred e colaboradores ${ }^{35}$ afirmam que há perda substancial da retenção do conhecimento decorrente da ausência de prática e de uso. Há muitos fatores que influenciam nesse resultado. Tarefas de cunho físico, natural e relacionados à alta velocidade estão menos susceptíveis ao esquecimento do que aquelas cognitivas, artificiais e ligadas à precisão e detalhamento. Vale lembrar que a prática de Odontologia requer ambas as habilidades, tanto a cognitiva quanto a física.

Além disso, variáveis metodológicas, como aplicação de testes em condições semelhantes à época de construção do conhecimento, e uso do critério comportamental de avaliação resultaram em menor perda de informação. Portanto, treinamento continuado auxilia na manutenção do conhecimento em domínios cognitivos mais elevados, fortalecendo a retenção dos estudos. ${ }^{36}$

Nilsson et al. ${ }^{37}$ (2011) concluíram que a habilidade em interpretar relações espaciais em radiografias dentárias foi melhor oito meses depois do treinamento suportado por simulador do que sem ele. O treinamento convencional, sem uso da tecnologia, teve resultado um pouco menor após oito meses, porém sem significância estatística. Stefanidis et al. ${ }^{38}$ (2005) avaliaram a retenção do conhecimento após o treinamento com simuladores para realização de laparoscopias. Concluíram que, apesar de os residentes não se lembrarem de todo o conhecimento, foi duradouro. A perda foi menor com o uso de vídeo-simuladores do que com o uso de Realidade Virtual (RV), após sete meses de treino. No entanto, como reportado na revisão sistemática "Effectiveness of e-learning in oral radiology education: a systematic 
review" (apêndice 1) do presente trabalho, não há evidência consistente na literatura de que os alunos treinados com uso de tecnologia retenham o conhecimento por mais tempo. Mais estudos se fazem necessários, especialmente voltados para a Odontologia.

\subsection{LIMITAÇÕES DO ESTUDO}

As limitações deste trabalho podem ser divididas nas seguintes categorias:

a) Tecnológica: para o desenvolvimento da RA, devido à ausência de verbas, foram utilizados unicamente softwares livres. Isso nos impôs limitação de espaço em bytes para gerar e salvar os modelos tridimensionais, bem como acesso restrito de ferramentas. Com softwares pagos, a qualidade dos modelos tridimensionais seria melhor e o uso da RA seria bem mais rápido e livre.

b) Metodológica: optamos por não oferecer recompensa aos alunos, com a finalidade de avaliar unicamente a atitude deles em relação às novas tecnologias. No entanto, se tivéssemos ofertado nota ou crédito, poderíamos ter resultados diversos. O viés seria incomensurável, já que os alunos poderiam realizar as atividades propostas unicamente visando a recompensa.

c) De Expectativa: O paradoxo encontrado baseia-se no fato de que, apesar de os estudantes terem atitude positiva em relação ao uso do e-learning, a participação foi baixa. O presente trabalho não encontrou respostas claras para tal fenômeno. Nesse aspecto, as pesquisas de Serres ${ }^{2}$ e November ${ }^{34}$ exploram possibilidades, conforme apresentado na discussão da dissertação.

d) Avaliativa: não foi enfoque do presente trabalho mensurar o ganho de conhecimento após o uso de tecnologia em Radiologia Oral e, por isso, não foram desenvolvidos métodos avaliativos específicos. O que propusemos foram pré e pós testes de conhecimento geral em Radiologia Oral, apenas para verificar o desempenho médio do grupo. 
e) Pedagógica: Montar um ambiente acolhedor de ensino na plataforma Moodle foi bastante desafiador, principalmente pelo fato de utilizarmos grande quantidade de imagens. A plataforma Moodle não se mostrou dinâmica e convidativa para disponibilizar imagens aos alunos, e ferramentas de desenho, edição e visualização de imagens não estão presentes.

f) De desenvolvimento: não foram desenvolvidas ferramentas para avaliar a percepção de utilidade e de efetividade do método, por não reconhecermos previamente ao desenvolvimento do estudo, que esses seriam os norteadores da pesquisa.

\subsection{O QUE APRENDEMOS COM ESSE TRABALHO}

- É de fundamental importância que os professores conheçam as características da atual geração digital para poderem desenvolver novos processos educacionais. Para isso, cabe às instituições de ensino incentivar, dar suporte, conhecimento e infraestrutura para que os educadores se arrisquem a utilizar métodos educacionais mediados por tecnologia.

- Alunos geralmente têm respostas positivas quanto ao uso do formato baseado em Internet para o aprendizado, mas a interação e participação em sala de aula ainda é considerada um componente indispensável à educação.

- Para que o e-learning seja melhor aceito pelos alunos, é necessário que tenham plena percepção de utilidade e de efetividade do método. Essa percepção deve ser despertada pelo ambiente de ensino criado pelo educador. Daí a importância da capacitação e infraestrutura dispensada ao corpo docente. 
- Evidências sugerem que o e-learning apresenta efetividade equivalente ao método tradicional de ensino em termos de ganho de conhecimento e performance em procedimentos clínicos em radiologia oral.

- E-learning para educação em Radiologia Oral é melhor utilizado como suporte ao conhecimento, e não como substituto às aulas tradicionais. Portanto, o método mais indicado para melhorar a disseminação do conhecimento é o ensino misto - tradicional e com uso de tecnologias.

- A Realidade Aumentada é uma nova perspectiva em Odontologia, apesar de estar em fase inicial. Pode ser criada pela integração de múltiplas tecnologias e tem grande potencial de auxiliar o ensino e a aprendizagem, e melhorar a forma como os modelos tridimensionais advindos de exames de imagens são visualizados.

- A tecnologia, por si só, não é capaz de transformar estudantes habituados a receber passivamente os conteúdos em alunos com trajetória autônoma. O professor tem função precípua de moderador do conhecimento.

- Estudantes parecem apresentar resistência em fazer pesquisas ou desenvolver atividades na Internet que exijam mais tempo e que envolvam maior nível de dificuldade. Também são facilmente desestimulados se necessitarem utilizar dispositivos pesados ou não portáteis. Além disso, não são capazes de processar a informação advinda de sites e mídias sociais em conhecimento. Por isso, o papel motivacional do professor é indispensável no processo educativo com uso de material instrucional tecnológico.

- O recebimento de recompensas, como nota ou crédito, ainda tem valor motivacional determinante no ensino brasileiro. 
- Os alunos brasileiros parecem encarar as Tecnologias de Informação e Comunicação como meio de comunicação, informação e diversão, mas não como ferramenta educacional.

- Mais estudos são necessários para comprovar a eficácia do ensino mediado por tecnologia ao longo do tempo. 
4. CONSIDERAÇÕES FINAIS 


\subsection{CONCLUSÃO}

No presente trabalho, observou-se que os alunos apresentaram interesse em aderir aos métodos educacionais mediados pela plataforma Moodle e via mídia social WhatsApp. Porém, ao longo dos semestres, a participação dos alunos caiu drasticamente devido à falta de percepção de utilidade dos conteúdos, seja por não comporem nota ou crédito, seja porque os estudantes não acreditaram que a carreira profissional requeria tal conhecimento. Além disso, a percepção de efetividade foi baixa, já que o conteúdo administrado via tecnologia não os auxiliou a tirar notas melhores nas provas e não houve aplicação prática por se tratarem de assuntos avançados em Radiologia Oral, que não compunham a rotina clínica.

Portanto, para que o e-learning seja efetivo, é necessário dar sentido à tecnologia. O emprego isolado das Tecnologias de Informação e Comunicação não garante o aprendizado nem instiga o interesse do estudante. $O$ desafio do docente é despertar no aluno a curiosidade pelas novas ferramentas de ensino, e todo uso de tecnologia deve ser acompanhado de um objetivo claro. 
5. REFERÊNCIAS BIBLIOGRÁFICAS 


\subsection{REFERÊNCIAS}

1. Castells MA. A sociedade em rede. São Paulo: Paz e Terra; 2002.

2. Serres M. Polegarzinha. Rio de Janeiro: Bertrand Brasil; 2013.

3. Paiva R, Toriani S, Lucio VR. Formação docente para o uso das tecnologias digitais. In: Silva, E L (Org.). Mídia-Educação: tecnologias digitais na prática do professor Curitiba: CRV; 2012. p. 105-16.

4. Freire P. Pedagogia da autonomia: saberes necessários à prática educativa. São Paulo: Paz e Terra; 1996.

5. Freire P. A Pedagogia do Oprimido. Rio de Janeiro: Paz e Terra; 1982.

6. Gabriel M. Educ@r: a (r)evolução digital na educação. São Paulo: Saraiva; 2013.

7. Silva EL. Uso da webquest na educação superior: balanço de dois anos de pesquisa. In: Silva, EL. Mídia-educação: tecnologias digitais na prática do professor Curitiba: CRV; 2012.

8. Ruiz JG, Mintzer MJ, Leipzig RM. The impact of e-learning in medical education. Academic Medicine. 2006;81:207-12.

9. Walker R, Dieter M, Panko W, Valenta A. What it will take to create new Internet initiatives in health care. Journal of Medical Systems. 2003;27:95-103.

10. Tidmarsh PJ, Cummings J, Hersh WR, Freidman CP. Distributed medical informatics education using Internet. Proceedings of the AMIA Symposium. 2002:78791.

11. Handal B, Groenlund C, Gerzina T. Dentistry students' perceptions of learning management systems. European Journal of Dental Education. 2010;14:50-4.

12. Higgins JPT, Green S. Cochrane handbook for systematic reviews of interventions. Version 5.0.2: The Cochrane Collaboration; 2009.

13. Rockhart JF. Chief executives define their own data needs. Harvard Business Review. 1979;57(2):238-41. 
14. Legris $\mathrm{P}$, Ingham J, Collerette P. Why do people use information technology? A critical review of the technology acceptance model. Information and management. 2003;40:191-204.

15. Bruner J. Factors motivating and inhibiting faculty in offering their courses via distance education. Online Journal of Distance Learning Administration. 2007;10. Retrieved from http://www.westga.edu/ distance/ojdla/summer102/bruner102.htm.

16. Gwebu KL, Wang J. The role of organizational, environmental and human factors in e-learning diffusion. International Journal of Web-Based Learning and Teaching Technologies. 2007;2:59-78.

17. Mahdizadeh $\mathrm{H}$, Biemans $\mathrm{H}$, Mulder $\mathrm{M}$. Determining factors of the use of elearning environments by university teachers. Computers and Education. 2008;51:142-54.

18. Walker G, Johnson N. Faculty intentions to use components for web-enhanced instruction. International Journal on E-learning. 2008;7:133-52.

19. Liaw SS, Huang HM, Chen GD. Surveying instructor and learner attitudes toward e-learning. Computers and Education. 2007;49:1066-80.

20. Nkenke E, Vairaktaris E, Bauersachs A, Eitner S, Budach A, Knipfer C, et al. Spaced education activates students in a theoretical radiological science course: a pilot study. BMC Medical Education. 2012;12(32). http://www.biomedcentral.com/1472-6920/12/32.

21. Felder RM, Brent R. Understanding student differences. Journal of Engineering Education. 2005;94(1):57-62.

22. Hayes J, Allison CW. Matching learning style and instructional strategy: an application of the person-environment interaction paradigm. Perceptual and Motor Skills. 1993;76:63-73.

23. Felder RM, Spurlin J. Applications, reliability and validity of the Index of Learning Styles. International Journal Of Engineering Education. 2005;21:103-12.

24. Dariel OP, Wharrad H, Windle R. Exploring the underlying factors influencing elearning adoption in nurse education. Journal of Advanced Nursing. 2012;69(6):1289300. 
25. Martín-Gutiérrez J, Fabiani P, Benesova W, Meneses MD, Mora CE. Augmented reality to promote collaborative and autonomous learning in higher education. Computers in Human Behavior. 2015;51:752-61.

26. Di Serio A, Ibáñez MB, Kloos CD. Impact of an augmented reality system on students' motivation for a visual art course. Computers and Education. 2013;68:58696.

27. Spallek H, Turner SP, Donate-Bartfield E, Chambers D, McAndrew M, Zarkowski P, et al. Social Media in the Dental School Environment, Part A: Benefits, Challenges, and Recommendations for Use. Journal of Dental Education. 2015;79(10):1140-52.

28. Nielsen J. College students on the web. December 15, 2010. At: www.nngroup.com/articles/college-students-on-the-web/.

29. Stein CD, Eisenberg ES, O'Donnell JA, Spallek $\mathrm{H}$. What dental educators need to understand about emerging technologies to incorporate them effectively into the educational process. Journal of Dental Education. 2013;78(4):520-9.

30. Kaplan AM, Haenlein M. Users of the world, unite! The challenges and opportunities of social media. Bus Horizon. 2010;53(1):59-68.

31. Rabelo ML, Bisinoto C. Perfil do estudante da UnB 2015. Universidade de Brasília; 2015.

32. Cummings $\mathrm{JN}$, Butler $\mathrm{B}$, Kraut $\mathrm{R}$. The quality of online social relationships. Communications of the ACM. 2002;45(7):103-8.

33. Surowiecki J. The wisdom of crowds. New York: Double-day; 2004.

34. November AC. Who Owns the Learning? Preparing Students for success in the Digital Age: Solution Tree Press; 2012. 104 p.

35. Winfred AJ, Winston BJ, Stanush PL, McNelly TL. Factors that influence skill decay and retention: a quantitative review and analysis. Human Performance. 1998;11(1):57-101.

36. Bloom BS, Engelhart MD, Furst EJ, Hill WH, Krathwohl DR. Taxonomy of educational objectives: the classification of educational goals. Handbook 1, cognitive domain. New York: David McKay Company; 1956. 
37. Nilsson TA, Hedman LR, Ahlqvist JB. Dental student skill retention eight months after simulator-supported training in oral radiology. Journal of Dental Education. 2011;75(5):679-84.

38. Stefanidis D, Korndorffer Jr JR, Sierra R, Touchard C, Dunne BJ, Scott DJ. Skill retention following proficiency-based laparoscopic simulator training. Surge 2005;138:165-70. 
6. APÊNDICES 


\section{APÊNDICE 1 - EFFECTIVENESS OF E-LEARNING IN ORAL RADIOLOGY EDUCATION: A SYSTEMATIC REVIEW}

Type of manuscript: Systematic Review.

\section{Authors:}

Glaucia Nize M Santos, Ms, André F Leite, PhD, Paulo T de S Figueiredo, PhD, Nara M Pimentel, PhD, Carlos Flores-Mir, DDS, DSc, FRCD(C), Nilce S de Melo, PhD, Eliete N S Guerra, PhD and Graziela De Luca Canto, PhD.

\section{Affiliation}

Ms. Glaucia Nize M Santos is a Postgraduate Student, Department of Dentistry, Health Sciences Faculty, University of Brasília, Brasília, Brazil; Prof. André F Leite, Dr. Paulo T de S Figueiredo and Dr. Nilce S de Melo are Associate Professors, Department of Dentistry, Health Sciences Faculty, University of Brasília, Brasília, Brazil; Prof. Nara M Pimentel is Associate Professor, Department of Education, University of Brasília, Brasília, Brazil; Dr. Flores-Mir is Associate Professor, Division Head of Orthodontics \& Orthodontic Graduate Program Director, Department of Dentistry, University of Alberta, Alberta, Canada. Prof. Eliete N S Guerra is Associate Professor, Oral Histopathology Laboratory, Health Sciences Faculty, University of Brasília, Brasília, Brazil and Dr. De Luca Canto is Associate Professor, Department of Dentistry, Federal University of Santa Catarina, Florianopolis, Santa Catarina, Brazil and Adjunct Assistant Professor, Department of Dentistry, University of Alberta, Alberta, Canada.

Corresponding author

Glaucia Nize Martins Santos

University Hospital of Brasilia. SGAN 605 Avenida L2 Norte Brasília - Distrito Federal,

DF, Brazil

Post code: $70840-901$

e-mail: nize.gal@gmail.com

tel: $+55619113-8119$ fax: + $55613326-3265$

Conflict of Interest: None.

Funding: This research was conducted without funding support. 
Title: Effectiveness of e-learning in oral radiology education: a systematic review.

\section{ABSTRACT}

Background: E-learning has been used lately in dental curricula to support the traditional learning method. However, published literature concerning e-learning in oral radiology has shown mixed conclusions.

Objective: To provide a synthesis of the effectiveness of e-learning in oral radiology education when compared with traditional classroom learning methods.

Search methods: Search was conducted on LILACS, PubMed, Science Direct, Scopus and Web of Science databases. Trials registries were also consulted for ongoing trials, and a partial grey literature search was also executed.

Selection criteria: Controlled trials about oral radiology education that compared any e-learning method with a control group using any traditional classroom instruction method. E-learning effectiveness was measured using three outcomes from Kirkpatrick's model of evaluation: attitude toward e-learning, knowledge gain and performance on clinical procedures.

Data collection and analysis: Data was analyzed descriptively. Qualitative appraisal was performed according to the Cochrane risk of bias tool for randomized trials and MINORS tool for non-randomized trials.

Results: Eleven studies met the inclusion criteria. Risk of bias was identified related to the selection procedures, blinding, lack of sample size calculation and incomplete analyses. Ten studies reported a positive attitude from students when using e-learning. Results from the knowledge gain outcome were mixed. Only two studies examined the performance on clinical procedures, showing contrasting results.

Conclusion: The evidence suggests that e-learning is at least as efficacious as traditional learning methods. Almost consistently students reported a more positive attitude towards e-learning. 
Keywords: Computer-Assisted Instruction; Dental Education; Education Measurement; Oral Radiology Education; Systematic Review.

\section{INTRODUCTION}

E-learning may be defined as any usage of computers and networks in education, in which the instructional content is delivered electronically when and where people need it. E-learning is also called Web-based learning, online learning, computer-assisted instruction (CAI), computer-assisted learning (CAL), or Internetbased learning. ${ }^{1,2}$ In the beginning, preceding the birth of the Internet, multimedia learning was built into disk operating system (DOS) software and the earliest computer-based learning programs utilized computer-assisted instructions (CAI). It was based on a question-and-answer game, supposed to stimulate the memorization of correct answers. The "teaching machine" invented by Skinner in $1954,{ }^{3}$ who founded the learning theory of behaviorism, is an example. ${ }^{4}$ In 1991, with the advent of the World Wide Web (WWW) it greatly facilitated the use of the learning theory using Internet. ${ }^{5}$ Although its potential as an instructional tool was quickly recognized, concerns about the effectiveness of Internet-based learning have led to a growing research field. ${ }^{6,7}$

With this technology, teachers are allowed to present learning content in a visually effective manner in digital environments, thereby hoping to promote user participation. Students may benefit from learning in their own time and preferred study pace/place. Additionally, predoctoral students have shown to prefer digital learning resources as opposed to more conventional materials such as textbooks. ${ }^{8,9}$ From the pedagogical point of view, electronic education has the potential to produce a paradigm shift from passive teacher-centered learning to active learner-centered learning. ${ }^{10}$

Computer-assisted learning (CAL) has increasingly been used in dental curricula to support traditional teaching and learning methods in various forms, such as computer or web-based tutorials or discussion groups, computerized patient simulations, and virtual reality-based simulations. ${ }^{11}$ It has been hypothesized that the technological shift may help dental education to meet expectations for higher-quality education, while at the same time saving costs in an era of reduced funding. ${ }^{12-14}$ 
The role of computers in oral radiology is paramount if compared to other areas of dentistry. It has to be considered that modern diagnostic imaging increasingly uses digital images that can be managed, stored and transmitted to and from different patient-centered locations through computer networks. A special advantage for Internet applications in radiology is related to the virtual limitless of the number of images that may be included in a computer document, when compared to a traditional book. ${ }^{15,}{ }^{16} \mathrm{~A}$ study highlighted the preference for computer-assisted learning and reference tools, when compared to reference books, by physicians in a medical radiology department. ${ }^{17}$

With continuous technological advances comes the challenge about how to best use them in oral radiology education. Therefore, educational researchers must test the effectiveness and efficiencies of the education mediated by computers to demonstrate their ability to be at least as effective as traditional methods of teaching, in order to clarify when to use technology-enhanced learning and how to best use it. ${ }^{18,19}$ Thus, the purpose of this systematic review was to synthesize the effectiveness of e-learning in comparison with in-class traditional learning methods in oral radiology education, applied to predoctoral students. It focusses on randomized and non-randomized controlled studies.

\section{METHODS}

\section{Protocol and registration}

This systematic review was reported according to the Preferred Reporting Items for Systematic Reviews and Meta-Analyses (PRISMA) Checklist. ${ }^{20}$ The protocol was registered in PROSPERO database ${ }^{21}$ under number CRD42015023747.

\section{Study design}

A systematic review that evaluated learning methods in the area of oral radiology was performed to answer the following question: "Among dental students, does e-learning compared to in-class traditional lecture learning method improve the learning in oral radiology?"

\section{Eligibility Criteria}

Inclusion criteria: 
Studies that evaluated e-learning in comparison to conventional classes among oral radiology students.

Exclusion criteria:

The studies were excluded in two phases.

In phase 1 (titles and abstracts) the following exclusion criteria were applied:

1. Studies in which computed technologies were not used as part of the educational content delivery;

2. Studies in which computed-aided learning methods were not used specifically for oral radiology education;

3. Reviews, letters, personal opinions, book chapters and conference abstracts.

4. Studies in different languages than English and Portuguese.

In phase 2 (full-text) these additional exclusion criteria were applied:

5. Panels presentation;

6. No in-class traditional learning method was used as comparison group;

7. Follow-up studies, in which skill/knowledge retention after e-learning was evaluated;

8. Studies about development of computer-assisted tool, in which it was not applied directly to oral radiology students.

\section{Information Sources and search strategy}

Individual search strategies for each of the following bibliographic databases were developed for the following databases: LILACS, PubMed, Science Direct, Scopus and Web of Science (more information on the individual search strategies is provided in Table 1). A partial grey literature search was taken using Google Scholar and ProQuest. The end search date was May 20, 2015 across all databases and the period of time evaluated was 92 years. Manual searches of reference lists of relevant articles and of some theses and dissertations were also performed.

All references were managed by reference manager software (Endnote $\mathrm{X} 7$, Thomson Reuters) and duplicate hits were removed with it. 


\section{Study Selection}

The selection was completed in 2 phases. In phase 1, two reviewers (G.N.M.S., A.F.L.) independently reviewed the titles and abstracts of all identified electronic database citations. Articles that did not appear to meet the inclusion criteria were discarded. In phase 2, the same reviewers applied the inclusion criteria to the full text of the articles. The references list of selected studies was also critically assessed by both examiners (G.N.M.S., A.F.L.). Any disagreement in first or second phase was resolved by discussion until a mutual agreement between the two authors was attained. When they did not reach a consensus a third author (P.T.S.F.) became involved to make a final decision.

\section{Data Collection Process and Data Items}

One author (G.N.M.S.) collected the required data from the selected articles. A second author (A.F.L.) crosschecked all the collected information. Again, any disagreement was resolved by discussion and mutual agreement between the 2 reviewers (G.N.M.S., A.F.L.). A third author (P.T.S.F.) was involved, when required, to make a final decision.

For each of the included studies, we recorded: author, year of publication, country, e-learning tool, traditional learning method, student educational level, outcome measures (pre-test, post-test and evaluation test), results and conclusion. If the required data were not complete, attempts were made to contact the authors to retrieve any pertinent missing information.

\section{Risk of Bias in Individual Studies}

Methodological Appraisal of Selected Studies Based on Methodological Index for non-randomized studies (MINORS) ${ }^{22}$ tool and The Cochrane Collaboration's tool for assessing risk of bias in randomised trials ${ }^{23}$ were applied. Regarding MINORS tool, two reviewers (G.N.M.S. and A.F.L.) scored 12 items as 0 (not reported), 1 (reported but inadequate) or 2 (reported and adequate). In The Cochrane Collaboration's tool the same reviewers classified the studies according to the risk of bias as low risk of bias (bias, if present, is unlikely to influence the results seriously), unclear risk of bias (a risk of bias that raises some doubt about the results) and high risk of bias (bias may influence the results seriously). 
Any disagreement was resolved by discussion until a mutual agreement between the 2 authors was attained. A third author (P.T.S.F.) became involved when required to make a final decision.

\section{Summary Measures}

The evaluation framework outlined by Kirkpatrick in the 1950s and later adapted to health care education can be used to evaluate e-learning interventions. ${ }^{24}$ It delineates four levels of training outcomes: reaction, learning, behavior, and results. Level one includes assessment of training participants' reaction to the training program, in terms of how well they liked a particular program. This measure is most commonly directed at assessing students' affective responses to the quality (e.g. satisfaction with the instructor or learning tool) or the relevance (e.g. work-related utility) of training. Level two, learning measures, are quantifiable indicators of the learning that has taken place during the course of the training. Level three behavior outcomes address either the extent to which knowledge and skills gained in training are applied on clinical procedures. Finally, level four outcomes are intended to provide some measure of the impact that training has had on broader university goals and objectives and patient outcome. ${ }^{1,24}$

Three outcomes measuring the effectiveness of e-learning in oral radiology education were evaluated based on Kirkpatrick's model of evaluation of learning in the human resources field: attitudes of students toward e-learning (reaction), knowledge gain (learning), and performance on clinical procedures (behavior).

\section{Synthesis of results}

A meta-analysis was planned if the data from the included studies was considered relatively homogeneous.

\section{Risk of bias across studies}

Only to be applied if meta-analysis was possible.

\section{RESULTS}

\section{Study Selection}


A total of 34 articles remained at the end of phase 1. Later 23 of those were excluded (more information on the excluded articles is provided in Appendix S1, which can be found in the supplemental data to the online version of this article). Therefore only eleven studies were finally selected. A flow chart of the process of identification, screening, eligibility and inclusion of studies is shown in Figure 1. It also presents the number of studies at different stages of the selection process.

\section{Study Characteristics}

The 11 selected articles were published in 3 different types of journals: dental ${ }^{25-}$ $30,34,35$, medical $^{31}, 32$ and educational ${ }^{33}$. The studies were conducted in different countries: Brazil, ${ }^{25-27,}{ }^{33}$ Brazil/Portugal, ${ }^{34}$ Germany, ${ }^{30-32}$ Greece, ${ }^{29}$ United Kingdom, ${ }^{35}$ and United States ${ }^{28}$. Ten studies were published in English25, 26, 28-35 and one in Portuguese 27 . Sample size ranged from $40^{33}$ to $228^{30}$ participants. A summary of study descriptive characteristics can be found in Table 2.

\section{Risk of Bias Within Studies}

From the eleven selected studies, six were non-randomized controlled trials and five were randomized trials.

MINORS were used to assess the risk of bias among the six non-randomized controlled trials. With the exception of two studies, ${ }^{25,29}$ the remaining non-randomized controlled trials $26,27,30,35$ scored poorly in relation to the MINORS criteria. (Table 3).

The Cochrane risk of bias tool (Table 4) was used to assess the risk of bias of the five randomized trials. Included studies ranged from moderate to high risk of potential bias. In two studies, there were no reports regarding allocation sequence generation or concealment. ${ }^{33,34}$ Blinding was described in only one study. ${ }^{33}$ Only three studies described outcome data for each main outcome. ${ }^{28,31,32}$ Furthermore, all selected randomized trials presented other sources of bias, mostly related to absence of sample size calculation.

\section{Synthesis of Results}

The following outcomes measurements were considered in this review:

\section{Attitudes toward e-learning (reaction)}


This qualitative outcome was evaluated in all studies using questionnaires administered to students. Ten studies ${ }^{25-30,32-35}$ reported a positive response from students when using e-learning. However, in one study, the students stated that the participation would be greater if they were rewarded with a higher test score. ${ }^{26}$ In one of the ten aforementioned studies, although the overall response was positive from students when using e-learning, more than $40 \%$ of them criticized the content. ${ }^{30}$ Finally, only one study showed no significant differences between the traditional group and technology-enhanced learning group, and students of both groups indicated that they would not appreciate more e-learning courses during their studies at University. ${ }^{31}$

\section{Knowledge gain (learning)}

The quantity of knowledge gain was investigated in eight studies using multiple choice questionnaires, ${ }^{25-27,} 29-31,34,35$ right/wrong questions, ${ }^{29}$ radiographic images to interpret and document, ${ }^{25,29,34}$ and written tests ${ }^{25}$. Results varied, with no statistically significant differences between e-learning compared to in-class traditional learning reported in four studies $(p=0.867, p=0.449, p=0.543, p=0.11)^{26,31,34,35}$ a higher score in e-learning students reported in two studies ${ }^{25,27}(\mathrm{p}=0.004)^{27}$ and a significant gain in knowledge using e-learning found in two studies $(p=0.005, p<0,001)^{29,30}$.

One study reported no initial significant differences in the post-test of the students of groups A (traditional learning) and B (interactive learning). ${ }^{34}$ However, 15 days later, students from group $B$ identified on average 0.25 more correct landmarks than did the group A students. In addition, another study ${ }^{35}$ showed higher exam grades of students who adopted both methods of learning (e-learning and face-to-face) when compared to exam grades of students who only used face-to-face lectures. In the same study, the exam grades of students who adopted only e-learning were similar of those who used e-learning associated with face-to-face lectures. The learning outcome results demonstrated that e-learning and association between both methods are similar to traditional classroom learning, in terms of knowledge gain.

\section{Performance on clinical procedures (behavior)}

Two studies examined the performance on clinical procedures in terms of obtain periapical radiographs by using Long Cone Paralleling Device ${ }^{28}$ and the bisectingangle technique. ${ }^{33}$ The former reported no significant differences $(p=0.3039)$ between 
the groups, even though the e-learning group had an average median score of 2.5 more total error points than the traditional learning group. ${ }^{28}$ The second study showed higher scores in e-learning group (mean grade in the e-learning group $=8.25$ and in the control group $=6.95)$, stating that virtual teaching was efficient in promoting the comprehension and training of taking intraoral radiographs. ${ }^{33}$

\section{Risk of Bias Across Studies}

The selected studies used similar methods, which reduced the possibility of misinterpretation. However, the studies did not have compatible data that would allow for a meta-analysis.

\section{DISCUSSION}

Nowadays, students taking courses in health science subjects are considerably different from those of previous generations, especially concerning the use of computers, familiarity with digital technologies and ease of use of digital learning environments. ${ }^{36}$ As teachers have a variety of tools to assist in teaching, training in computer-aided techniques is increasingly used in medical and dental education. 6-11, $18,25-47$ In fact, for radiology the role of the computer is clearly more decisive than it is for other general disciplines as the diagnostic imaging area gradually uses more digital images. ${ }^{16,48}$

This is the first systematic review that assessed the effectiveness of e-learning in oral radiology education as compared to in-class traditional learning methods. Eleven studies met the inclusion criteria. In our systematic review, six of the eleven selected studies found no significant improvement in knowledge gain and two studies reported a significant gain in knowledge using e-learning in oral radiology. These results support previous findings of e-learning knowledge gain in other dental sciences. ${ }^{39,40,47}$ There are many confounders factors in learning that were not accounted or controlled in the reported studies, such as the level of motivation of the students, previous knowledge of the subject, and learning style, as well as the teaching style of the educator, that can explain the aforementioned results. ${ }^{49,50}$ Furthermore, traditional evaluation methods such as written tests, multiple choice questionnaires and right/wrong questions have been used in all selected studies for evaluating 
knowledge gain. It is unclear to what extent these evaluation methods can measure the effectiveness of e-learning and how they have influenced the outcome of the selected studies regarding knowledge gain.

In addition, any e-learning implementation requires further assessments even after the observation of positive results when indicating its effectiveness compared to conventional educational methods. ${ }^{51}$ It was stated that when technology is used as a complement and not as a substitute, then the outcome will be better. ${ }^{26} \mathrm{~A}$ study compared blended courses with fully online and face-to-face courses and reported that the blended model was comparable to or - in some cases - better than face-to-face, as far as the student grades were concerned. ${ }^{52}$ This statement was supported by other studies, 29, 30, 35 in which students using e-learning associated with traditional learning showed higher grades than face-to-face learning only. One study ${ }^{33}$ showed that a computer program, should be explored as an additional teaching aid because it allows students to learn theory and put it in practice, make mistakes and learn with them, and develop problem-solving skills before real contact with patients.

E-learning positively influences the students, but there is a necessity to evaluate the contexts and purposes in which these technologies should be used. Conventional teachers must learn the necessary technological skills, pedagogical principles and teaching strategies to create effective educational online environments. ${ }^{52} \mathrm{~A}$ previous study found that it takes more time to convert e-learning modules than to prepare faceto-face lectures. ${ }^{53}$ In this context, a lack of computer knowledge and skills has been identified as a major barrier in adopting e-learning in the practice of learning. ${ }^{54}$

Moreover, there is no consistent evidence in the literature that students trained with an interactive learning will retain information longer. An included study showed better results in using computer-aided education when evaluating knowledge retention in a 15 days period. ${ }^{34}$ In another included study it was stated that students were positive in receiving multiple choice questions via e-mail two weeks after lectures. ${ }^{32}$ This may demonstrate an improvement in knowledge acquisition and a boost in knowledge retention. ${ }^{55}$ On the other hand, it was related that the members of the technology-enhanced learning group put the usefulness of the system into question, as they were significantly less confident in being successful in the exam when 
compared to the traditional group, although they both groups were successful in the exam afterwards. ${ }^{31}$ This aspect may be related to a criticism sometimes made of elearning, that is perceived as remote and impersonal. ${ }^{56}$

Regarding students' perception toward e-learning, only one study showed no statistically significant differences between the traditional group and technologyenhanced learning group. ${ }^{31}$ It was stated that e-learning is appreciated by students especially when it includes topics that use real-world examples, as in case of dental radiology. ${ }^{30}$ Additionally, these authors reported that online learning allows students to manage their own learning, develop active learning skills and improve competencies in decision-making, opinion and reflection. A study stated that the quality of e-learning material and the students' evaluation are important factors in determining the success of web-based courses in higher education. ${ }^{29}$ Also efficiency of their e-learning course was very high due to the material organization, that followed the distance learning and student-centered principles (independent learning, interaction, clarity, friendliness and motivation). Furthermore, the material was unique, developed especially for this course and it did not resemble any existing written or electronic material. Previous studies report that students generally have a positive response to web-based instructional formats, but that classroom interaction and participation are still seen as a necessary component to education. ${ }^{57}$ Students prefer that online modules are used as a support to learning ${ }^{58}$ and they dislike the replacement of traditional lectures by the online format. ${ }^{59} \mathrm{It}$ is therefore desirable that online courses are not established just to bring technology as a tool into the curriculum but rather for enhancing and enriching education. ${ }^{60}$

In summary, e-learning in oral radiology education is more properly used as a support to the traditional education and not as a substitute to it. Although creating the e-learning modules is time consuming and requires special skills from the educator, it is worth as students are positive to receive this material and it can be easily updated and delivered to many students at the same time, without more staff being necessary.

\section{Limitations}

Overall, the number of studies published on the use of e-learning in oral radiology education in comparison with traditional learning methods is relatively limited 
and thus contributed to scarce available information synthesized in this systematic review. Limitations where found in the selected studies, especially due to the variability in their scientific design and failure to define the content quality and type of specific elearning intervention being analyzed. In addition, most have included several different instructional and delivery methodologies, which turns the analysis complicated. This systematic review has grouped many studies that address varied subject matter within the broad category, oral radiology. There are studies that are evaluating e-learning in radiation physics, protection etc or radiographic technique which are inherently very different and require varied learning skills for achieving competence and understanding. For the studies that did include radiographic interpretation, the extent and topics are very different, ranging from anatomic landmark identification to radiopaque-radiolucent pathology. Furthermore, regarding the quality appraisal of the included studies, risk of bias was found related to the selection procedures, blinding, lack of sample size calculation and incomplete analyses. Also, only undergraduate students were evaluated in all the studies. The potential effect on graduate students is unknown in dental radiology. It is also important to consider that learning is a deeply personal experience, and the learning environment, defined as the social, psychological and pedagogical contexts in which learning occurs and which affect student achievement and attitudes, is not evaluated in the social and psychological aspects in the selected studies, but only in the pedagogical context. ${ }^{52}$

\section{CONCLUSION}

In conclusion, evidence suggests that e-learning shows equivalent effectiveness as traditional classroom method in knowledge gain and performance on clinical procedures of oral radiology contents. Furthermore, in general, predoctoral students consistently reported positive attitudes towards e-learning. Although further studies are necessary to verify the effectiveness of e-learning, it is strongly associated with the modern technology for the acquisition of images in radiology.

\section{References}

1. Ward JP, Gordon J, Field MJ, Lehmann HP. Communication and information technology in medical education. Lancet. 2001;357:792-96. 
2. Zhang D, Nunamaker JF. Powering e-learning in the new millennium: an overview of e-learning and enabling technology. Inform Syst Front 2003;5(2):207-18.

3. Skinner BF. The science of learning and the art of teaching. Harv Educ Rev 1954;8697.

4. Liaskos J, Diomidus M. Multimedia technologies in education. Stud Health Technol Inform 2002; 65:359-372.

5. Berners-Lee T, Cailliau R, Luotonen A, et al. The World-Wide Web. Commun ACM 1994;37(8):76-82.

6. Friedman RB. Top ten reasons the World Wide Web may fail to change medical education. Acad Med 1996;71(9):979-981.

7. MacKenzie JD, Greenes RA. The World Wide Web: redefining medical education. JAMA 1997;278(21):1785-6.

8. Schittek M, Mattheos N, Lyon HC, Attstrom R. Computer-assisted learning. A Review. Eur J Dent Educ 2001;5:93-100.

9. Vuchkova J, Maybury T, Farah CS. Digital interactive learning of oral radiographic anatomy. Eur J Dent Educ 2011;15:1-9.

10. Pahinis K, Stokes CW, Walsh TF, et al. A blended learning course taught to different groups of learners in a dental school: follow-up evaluation. J Dent Educ 2008;72:1048-1057.

11. Buchanan JA. Use of simulation technology in dental education. J Dent Educ $2001 ; 65(11): 1225-31$.

12. Cornell R. The onrush of technology in education: the professor. Educ Technol 1999;39:60-64.

13. Garrison D, Kanuka H. Blended learning: uncovering its transformative potential in higher education. Internet High Educ 2004;7:95-105. 
14. Mayes T. Teaching, technology and talk: Psychology and advanced learning ought to go well together. Psychologist 1998;11:375-377.

15. Pozzi MR. Teleradiology, telecommunications, e-learning. Radiol Med 2001;102(12):1.

16. Scarsbrook AF, Foley PT, Perriss RW, Graham RN. Radiological digital teaching file development: an overview. Clin Radiol 2005;60:831-837.

17. Gutmark R, Halsted MJ, Perry L, Gold G. Use of computer databases to reduce radiograph reading errors. J Am Coll Radiol 2007;4:65-68.

18. Schonwetter DJ, Reynolds PA, Eaton KA, De Vries J. Online learning in dentistry: an overview of the future direction for dental education. J Oral Rehabil 2010;37:927940.

19. Cook DA. The failure of e-learning research to inform educational practice, and what we can do about it. Med Teach 2009; 31:158-162.

20. Moher D, Liberati A, Tetzlaff J, Altman DG, PRISMA Group. Preferred reporting items for systematic reviews and meta-analyses: the PRISMA statement. Open Med 2009;3:e123-30.

21. Prospero. University of York: Centre for Reviews and Dissemination. 2015. At: http://www.crd.york.ac.uk/PROSPERO/. Accessed: August 29, 2015.

22. Slim $\underline{K}$, Nini E, Forestier $\mathrm{D}$, et al. Methodological Index for non-randomized studies (MINORS): development and validation of a new instrument. J Surg 2003;73:712-716.

23. Higgins JP, Altman DG, Gøtzsche PC, et al. The Cochrane Collaboration's tool for assessing risk of bias in randomised trials. BMJ 2011;343:d5928.

24. Kirkpatrick DL. Evaluating training programs: the four levels. San Francisco: Berrett-Koehler, 1994. 
25. Busanello FH, Silveira PF, Liedke GS, et al. Evaluation of a digital learning object (DLO) to support the learning process in radiographic dental diagnosis. Eur J Dent Educ 2014. Article first published online: 13 nov 2014.

26. Cruz AD, Costa JJ, Almeida SM. Distance learning in dental radiology: Immediate impact of the implementation. Braz Dent Sci 2014;17(4): 90-97.

27. Deluiz LF, Carvalho. ACP, Almeida CAP. Assessment of a self-instructional teaching method to identify errors in taking dental radiographs. [Avaliação do método auto-instrutivo no ensino para identificação dos erros na confecção de radiografias odontológicas.] Rev Bras Odontol 2005; 62(1-2):64-67.

28. Howerton WBJ, Platin E, Ludlow J, Tyndall DA. The influence of computerassisted instruction on acquiring early skills in intraoral radiography. J Dent Educ 2002;66(10):1154-8.

29. Kavadella A, Tsiklakis K, Vougiouklakis G, Lionarakis A. Evaluation of a blended learning course for teaching oral radiology to undergraduate dental students. Eur $\mathrm{J}$ Dent Educ 2012;16(1):e88-95.

30. Meckfessel S, Stühmer C, Bormann $\mathrm{KH}$, et al. Introduction of e-learning in dental radiology reveals significantly improved results in final examination. $\mathrm{J}$ Craniomaxillofac Surg 2011; 39(1):40-48.

31. Nkenke E, Vairaktaris E, Bauersachs A, et al. Acceptance of technology-enhanced learning for a theoretical radiological science course: a randomized controlled trial. BMC Med Educ 2012;12:18.

32. Nkenke $E$, Vairaktaris $E$, Bauersachs $A$, et al. Spaced education activates students in a theoretical radiological science course: a pilot study. BMC Med Educ 2012;12:32.

33. Silveira HLD, Liedke G, Dalla-Bona RR, Silveira HE. Development of a graphic application and evaluation of teaching and learning of the bisecting-angle technique for periapical radiographs. Educação, Formação \& Tecnologias 2008;1(2): 59-65. 
34. Silveira HL, Gomes MJ, Silveira HE, Dalla-Bona RR. Evaluation of the radiographic cephalometry learning process by a learning virtual object. Am J Orthod Dentofacial Orthop 2009;136(1):134-138.

35. Tan $\underline{\mathrm{PL}}, \underline{\text { Hay } \mathrm{DB}}, \underline{\text { Whaites } \mathrm{E}}$. Implementing e-learning in a radiological science course in dental education: A short-term longitudinal study. J Dent Educ 2009;73(10):1202-12.

36. Hu J, Yu H, Shao J, et al. Effects of 3D multimedia system of the performance of junior dental students in preclinical practice: a report of China. Adv Health Sci Educ Theory Pract 2009;14:123-133.

37. Reilly JR, Gallagher-Lepak S, Killion C. "Me and my computer": emotional factors in online learning. Nurs Educ Perspect 2012;33:100-105.

38. Leblanc V, Urbankova A, Hadavi F, Lichtenthal R. A preliminary study in using virtual reality to train dental students. J Dent Educ 2004;68:378-383.

39. Al-Jewair TS, Azarpazhooh A, Suri S, Shah PS. Computer-Assisted Learning in Orthodontic Education: A Systematic Review and Meta-Analysis. J Dent Educ. 2009;73(6):730-9.

40. Al-Jewair TS, Qutub AF, Malkhassian G, Dempster LJ, A Systematic Review of Computer-Assisted Learning in Endodontics Education. J Dent Educ. 2010;74(6):60111.

41. Cook DA, Levinson AJ, Dupras DM, et al. Internet-based learning in the health professions. JAMA 2008;300(10):1181-96.

42. Khayat A, Keshtkar A. A comparative study of multimedia and conventional education methods in undergraduate training in preclinical endodontics. J Res Med Sci $2004 ; 4: 40-3$.

43. Zafar S, Safdar S, Zafar AN. Evaluation of use of e-learning in undergraduate radiology education: A review. Eur J Radiol 2014;83:2277-2287. 
44. Marshall NL, Spooner M, Galvin PL, et al. Informatics in radiology: evaluation of an e-learning platform for teaching medical students competency in ordering radiologic examinations. Radiographics 2011;31(5):1463-74.

45. Grunewald M, Heckemann RA, Gebhard H, et al. Compare radiology: creating an interactive web-based training program for radiology with multimedia authoring software. Acad Radiol. 2003;10(5):543-53.

46. Zeiler C, Mangel E, Schenk F, Pfeifer K-J. Do computers teach better? A media comparison study for case-based teaching in radiology. Radiographics. $2001 ; 21: 1025-32$.

47. Rosenberg H, Grad HA, Matear DW. The effectiveness of computer-aided, selfinstructional programs in dental education: a systematic review of the literature. J Dent Educ 2003;67(5):524-32.

48. Wenzel A, Moystad A. Work flow with digital intraoral radiography: a systematic review. Acta Odontol Scand. 2010;68(2):106-14

49. Devitt $P$, Palmer E. Computer-aided learning: an overvalued educational resource? Med Educ 1999;33:136-9.

50. Kukolja-Taradi S, Dogas Z, Dabić M, Drenjancevic Perić I. Scaling-up undergraduate medical education: enabling virtual mobility by online elective courses. Croat Med J 2008;49(3):344-51.

51. Al-Rawi WT, Jacobs R, Hassan BA, et al. Evaluation of web-based instruction for anatomical interpretation in maxillofacial cone beam computed tomography. Dentomaxillofac Radiol 2007;36(8):459-64.

52. Dziuban CD, Hartman JL, Moskal PD. Blended learning. EDU-CAUSE Center Appl Res Bull 2004;7:1-12. At: http://net.educause.edu/ir/library/pdf/ERB0612.pdf. Accessed: July 17, 2015. 
53. Andrews KG, Demps EL. Distance education in the U.S. and Canadian undergraduate dental curriculum. J Dent Educ 2003;67(4):427-38.

54. Gagnon MP, Légaré $F$, Labrecque $M$, et al. Perceived barriers to completing an elearning program on evidence-based medicine. Inform Prim Care 2007;15:83-91.

55. Kerfoot BP, Armstrong EG, O'Sullivan PN: Interactive spaced education to teach the physical examination: a randomized controlled trial. J Gen Intern Med 2008;23:973-978.

56. Harden RM, Gessner IH, Gunn M, et al. Creating an e-learning module from learning objects using acommentary or 'personal learning assistant'. Med Teach $2011 ; 33: 286-290$.

57. Ginns P, Ellis R. Quality in blended learning: exploring the relationships between online and face-to-face teaching and learning. Internet High Educ 2007;10:53-64.

58. Durham JA, Brettell S, Summerside C, McHanwell S. Evaluation of a virtual anatomy course for clinical undergraduates. Eur J Dent Educ 2009;13:100-109.

59. Linjawi AL, Hamdan AM, Perryer DG, et al. Students' attitudes towards an on-line orthodontic learning resource. Eur J Dent Educ 2009;13:87-92.

60. Fraser BJ. The birth of a new journal: editor's introduction. Learn Environ Res $1998 ; 1: 1-5$. 
Appendix S1. Excluded articles and reasons for exclusion $(n=23)$.

Author, Year

Al-Rawi et al, 2015

Al-Rawi et al, 2007

2

3

4

5

6

7

8

9

10

11

12

13

14

15

16

17

18

19

20

21

22

23
Ávila, 2004

2

Baños et al, 2010

2

Broome, 2011

2

Casper, 2012

Cohen et al, 2003

1

Evers, 2012

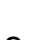

Häll, 2012

2

Hassan et al, 2007

4

Hintze et al, 1988

2

Kavadella, 2007

1

Mileman et al, 2004

4

Nilsson et al, 2011

3

Salajan et al, 2009

2

Sánchez -Villalobos et al, 2011

1

Silva, 2013

1

Tanimoto et al, 2006

4

Tapias Torrado et al, 2012

2

Thang et al, 2014

1

Vuchkova et al, 2012

2

Wenzel, Gotfredsen, 1997

3

Wenzel, Gotfredsen, 1988 
1- Panels presentation $(n=5)$; 2- No in-class traditional learning method was used as comparison group; $(n=12)$; 3- Follow-up studies, in which skill/knowledge retention after elearning was evaluated $(n=2)$; and 4- Studies about development of computer-assisted tool, in which it was not applied directly to oral radiology students $(n=4)$.

\section{REFERENCES}

1. Al-Rawi WT, Easterling L, Edwards PC. Development of a mobile device optimized cross platform-compatible oral pathology and radiology spaced repetition system for dental education. J Dent Educ 2015; 79(4):439-447.

2. Al-Rawi WT, Jacobs R, Hassan BA, et al. Evaluation of web-based instruction for anatomical interpretation in maxillofacial cone beam computed tomography. Dentomaxillofac Radiol 2007; 36(8):459-464 .

3. Ávila MAG. Software anatomia em radiografias panorâmicas: avaliação do método de ensino-aprendizado em odontologia. São Paulo. 2004.

4. Baños MA, Sánchez PC, Beneyto YM, et al. Tele-enseñanza a través de internet: la protección radiológica en ciencias de la salud. EKSP. 2010;11(2): 232-260.

5. Broome AM. E-learning for radiographic interpretation: development of a testing module.The University of North Carolina at Chapel Hill. 2011, 91 pages.

6. Casper RJ. Development of a three-dimensional learning resource of the pterygopalatine fossa using cone beam computed tomography for dental students. Ann Arbor, Creighton University. 2012, 42 pages. 
7. Cohen HB, Walker SR, Tenenbaum HC, et al. Interdisciplinary, web-based, self-study, interactive programs in the dental undergraduate program: a pilot. $J$ Dent Educ 2003; 67(6):661-667.

8. Evers MEJ. Development and testing of a CBCT educational module for dental providers in the US Navy. The University of North Carolina at Chapel Hill. 2012, 42 pages.

9. Häll LO. Exploring Collaborative Training with Educational Computer Assisted Simulations in Health Care Education: An Empirical Ecology of Resources Study. CE 2012; 3(special issue):784-795.

10. Hassan BA, Jacobs R, Scarfe WC, Al-Rawi WT. A web-based instruction module for interpretation of craniofacial cone beam $\mathrm{CT}$ anatomy. Dentomaxillofac Radiol 2007;36(6): 348-355.

11. Hintze H. Students' Attitudes towards Control Methods in Computer-Assisted Instruction. J Comp Assist Learn 1988;4(1): 3-10.

12. Kavadella A. Comparative evaluation of the educational effectiveness of two didactic methods conventional and blended learning in teaching dental radiology to undergraduate students. Eur J Dent Educ 2007;11(2): 112-124.

13. Mileman PA, van den Hout WB, Sanderink GC. Looking for caries...? Teachers evaluate a program to improve caries diagnosis from radiographs. Eur J Dent Educ 2004;8(1): 35-42

14. Nilsson TA, Hedman LR, Ahlqvist JB. Dental student skill retention eight months after simulator-supported training in oral radiology. J Dent Educ 2011;75(5): 679-684. 
15. Salajan FD, Perschbacher S, Cash M, Talwar R, El-Badrawy W, Mount G. Learning with web-based interactive objects: An investigation into student perceptions of effectiveness. Comput Educ 2009;53(3): 632-643

16. Sánchez Villalobos JM, Andreu-Gálvez M, Alcaraz-Saura M, Achel GD, Alcaraz M. Tele-enseñanza a través de internet: la protección radiológica en ciencias de la salud= E-learning through internet: radiological protection in health sciences. Congreso Internacional de Innovación Docente. Universidad Politécnica de Cartagena. 2011.

17. Silva AM. Desenvolvimento de um objeto digital para aprendizagem do diagnóstico de alterações radiográficas do complexo dento-alveolar. UFRGS, Porto Alegre, RS. 2013.

18. Tanimoto H, Gröndahl H, Gröndahl K, Arai Y. Further development of a versatile computer-assisted learning program for dental education with an exemplifying application on how to logically arrange and mount periapical and bitewing radiographs. Oral Radiol 2006; 22(2):75-79.

19. Tapias Torrado L, López E, Sierra L, Marinez B, Natalia Mesa F, Román JP. Importancia de diseñar, implementar y evaluar un Objeto Virtual de Aprendizaje en radiología oral, como material de apoyo a la docencia. Ciencia y Salud Virtual 2012; 4(1):93-101.

20.Thang A. Three-Dimensional Virtual Simulator for Teaching Bitewing Radiography. Oral Surg Oral Med Oral Pathol Oral Radiol Endod 2014;117(5): e421.

21. Vuchkova J, Maybury T, Farah CS. Digital interactive learning of oral radiographic anatomy. Eur J Dent Educ 2012; 16(1):E79-E87. 
22. Wenzel A, Gotfredsen E. Students' attitudes towards and use of computerassisted learning in oral radiology over a 10-year period. Dentomaxillofac Radiol 1997; 26(2):132-136.

23.Wenzel A, Gotfredsen E. Learner - versus teacher- controlled structure in computer-assisted instruction for intraoral radiography. Dentomaxillofac Radiol 1988;17:49-55. 


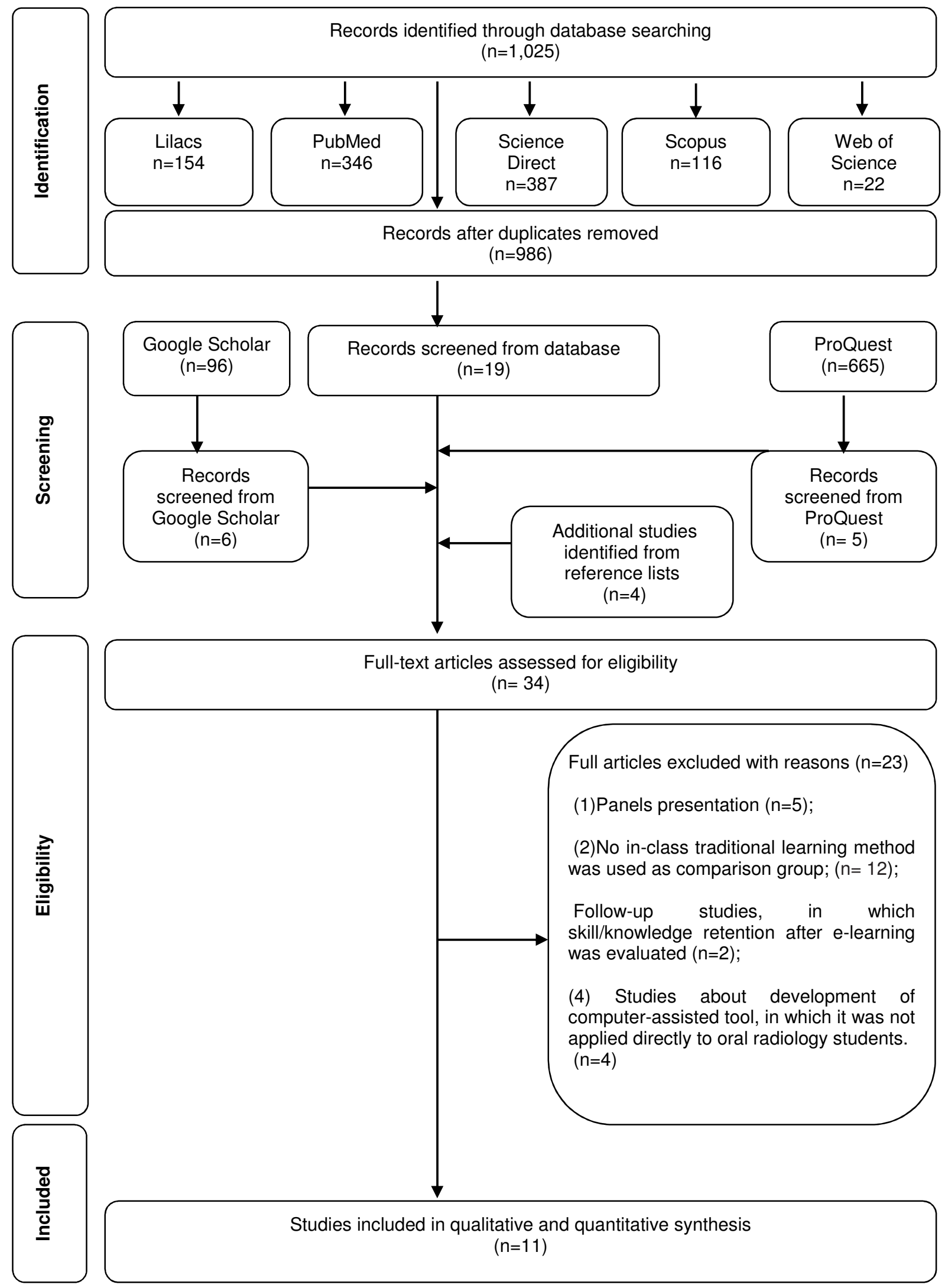

Figure 1. Flow diagram illustrating the literature search protocol and selection criteria adapted from PRISMA. ${ }^{20}$ 
Table 1. Database Search.

LILACS (May 20, 2015)

Pubmed (May 20, 2015)

Science Direct (May 20, 2015)

Scopus (May 20, 2015)

Web of Science (May 20, 2015)

Google Scholar (May 20, 2015) (e-learning) or "E-LEARNING" [Palavras] or (educação) or educación or "EDUCACAO CONTINUADA EM ODONTOLOGIA" [Palavras] and (radiologia) or radiología or "RADIOLOGISTAODONTOLOGO" [Palavras]

\# 1 "oral radiology" OR "dental radiologic science course" OR "dental radiology" OR "oral radiologic science course" OR "craniofacial radiology" OR "head and neck radiology";

\#2 e-learning OR "computed-aided learning" OR "self instruction learning" OR "self instruction programs, computerized" OR "programmed learning" OR "blended learning" OR "Selfinstruction Programs" OR "Program, Self-Instruction" OR "Programs, Self-Instruction" OR "Self Instruction Programs" OR "Self-Instruction Program" OR "Learning, Programmed" OR "computer assisted learning" OR "web based education" OR "computational intelligence" OR "computer vision system" OR "knowledge representation (computer)" OR "computer reasoning" OR "machine learning" OR "computer based learning" OR technology OR "computerized programmed instruction" OR "instruction, computer assisted" OR "self instruction program, computerized" OR "online learning" OR "computerized assisted instruction" OR "online courseware" OR "web based learning" (\#1 AND \#2)

"oral radiology" OR "dental radiologic science course" OR "dental radiology" OR "oral radiologic science course" OR "craniofacial radiology" OR "head and neck radiology" AND e-learning OR "computed-aided learning" OR "self instruction learning" OR "self instruction programs, computerized" OR "programmed learning" OR "blended learning" OR "Self-instruction Programs" OR "Program, Self-Instruction" OR "Programs, Self-Instruction" OR "Self Instruction Programs" OR "Self-Instruction Program" OR "Learning, Programmed" OR "computer assisted learning" OR "web based education" OR "computational intelligence" OR "computer vision system" OR "knowledge representation (computer)" OR "computer reasoning" OR "machine learning" OR "computer based learning" OR technology OR "computerized programmed instruction" OR "instruction, computer assisted" OR "self instruction program, computerized" OR "online learning" OR "computerized assisted instruction" OR "online courseware" OR "web based learning"

e-learning

oral radiology 
ProQuest (May 20, 2015)

"oral radiology" OR "dental radiologic science course" OR "dental radiology" OR "oral radiologic science course" OR "craniofacial radiology" OR "head and neck radiology" AND e-learning OR "computed-aided learning" OR "self instruction learning" OR "self instruction programs, computerized" OR "programmed learning" OR "blended learning" OR "Self-instruction Programs" OR "Program, Self-Instruction" OR "Programs, Self-Instruction" OR "Self Instruction Programs" OR "Self-Instruction Program" OR "Learning, Programmed" OR "computer assisted learning" OR "web based education" OR "computational intelligence" OR "computer vision system" OR "knowledge representation (computer)" OR "computer reasoning" OR "machine learning" OR "computer based learning" OR technology OR "computerized programmed instruction" OR "instruction, computer assisted" OR "self instruction program, computerized" OR "online learning" OR "computerized assisted instruction" OR "online courseware" OR "web based learning" 
Table 2. Summary of descriptive characteristics of included studies $(n=11)$.

\begin{tabular}{|c|c|c|c|c|c|c|c|c|c|}
\hline \multirow[t]{3}{*}{$\begin{array}{l}\text { Author (s)/ } \\
\text { Year }\end{array}$} & \multirow[t]{3}{*}{ Country } & \multirow[t]{3}{*}{ Learning method } & \multicolumn{2}{|c|}{ Subjects ${ }^{*}$} & \multicolumn{3}{|c|}{$\begin{array}{l}\text { Outcome Measures } \\
\text { Kirkpatrick's levels }\end{array}$} & Results & Conclusion \\
\hline & & & $\begin{array}{l}\text { Test Group } \\
\text { (E-learning) }\end{array}$ & $\begin{array}{c}\text { Control Group } \\
\text { (Traditional } \\
\text { classroom } \\
\text { learning) }\end{array}$ & & & & & \\
\hline & & & $\mathbf{N}$ & $\mathbf{N}$ & reaction & learning & behavior & & \\
\hline $\begin{array}{l}\text { Busanello et } \\
\text { al, } 2014^{25}\end{array}$ & Brazil & $\begin{array}{l}110 \text { periapical and } \\
\text { interproximal digitized } \\
\text { radiographs were } \\
\text { graphically manipulated in } \\
\text { order to create a digital } \\
\text { learning object (DLO). } \\
\text { Additionally to the } \\
\text { processed images, the } \\
\text { DLO included exercises } \\
\text { and a quiz. }\end{array}$ & 31 & 31 & $y$ & y & $n$ & $\begin{array}{l}\text { Students taught using a } \\
\text { DLO achieved } \\
\text { statistically significantly } \\
\text { higher scores compared } \\
\text { to students taught } \\
\text { through conventional } \\
\text { classes. The study } \\
\text { showed high degree of } \\
\text { DLO usability and } \\
\text { satisfaction. }\end{array}$ & $\begin{array}{l}\text { DLO may be a useful } \\
\text { teaching tool for } \\
\text { dentistry } \\
\text { undergraduates, on } \\
\text { distance learning } \\
\text { courses and as a } \\
\text { complimentary tool in } \\
\text { face-to-face teaching }\end{array}$ \\
\hline $\begin{array}{l}\text { Cruz et al, } \\
2014^{26}\end{array}$ & Brazil & $\begin{array}{l}\text { Moodle e-course about } \\
\text { dento-maxillo- } \\
\text { mandibular anatomy, } \\
\text { using digitized periapical } \\
\text { radiographs with } \\
\text { anatomical landmarks. } \\
\text { The e-course was } \\
\text { designed as topics of } \\
\text { questionnaires on which } \\
\text { each question with } \\
\text { description of the } \\
\text { anatomical structures } \\
\text { had associated an } \\
\text { image. }\end{array}$ & 62 & 60 & $y$ & y & $\mathrm{n}$ & $\begin{array}{l}\text { In terms of student's } \\
\text { scores there were no } \\
\text { significant differences } \\
\text { between both classes. } \\
\text { The present findings } \\
\text { indicate the e-learning to } \\
\text { be an efficient method of } \\
\text { learning. }\end{array}$ & $\begin{array}{l}\text { The method of e- } \\
\text { learning of this subject } \\
\text { using the Moodle } \\
\text { platform can be } \\
\text { utilized with the same } \\
\text { educational results of } \\
\text { those obtained from a } \\
\text { traditional educational } \\
\text { setting. }\end{array}$ \\
\hline $\begin{array}{l}\text { Deluiz et al, } \\
2005^{27}\end{array}$ & Brazil & $\begin{array}{l}\text { Development of a } \\
\text { multimedia CD-rom. The }\end{array}$ & 80 & 80 & $y$ & $y$ & $\mathrm{n}$ & $\begin{array}{l}C D \text { helped students } \\
\text { visualize errors in oral }\end{array}$ & $\begin{array}{l}\text { The development and } \\
\text { application of the }\end{array}$ \\
\hline
\end{tabular}


learning content was about errors in

exposure, processing

radiographs.
and interpretation

$$
\text { adiographs. }
$$

$\begin{array}{ccc}\begin{array}{c}\text { Howerton } \\ \text { et al, } 2002^{28}\end{array} & \text { United } & \text { Interactive computer- } \\ & \text { States } & \text { assisted instructional } \\ & \text { (CAl) module on CD. } \\ & \text { The content of the } \\ & \text { multimedia instruction } \\ \text { focused on intraoral } \\ \text { radiography featuring } \\ \text { use of the XCP } \\ \text { Instrument and } \\ \text { exposing, developing, } \\ \text { and mounting dental } \\ \text { radiographs. }\end{array}$

radiographs. $93,93 \%$ of students would use $C D$ to study more topics in oral radiology.

\section{$C D$ helped students understand and} visualize exposure of radiographs; the $C D$ helped students set up and manipulate the XCP instruments; and

$$
\text { students would }
$$

recommend the use of

the interactive $C D$ to

$$
\text { others. }
$$

The median error scores for students who used the $C D$ were higher than students who did not.

Students of the blended learning group performed significantly better at the end of the course than the students of the conventional group. mixed radiolucent-

lesions, uploaded to the educational platform of the Dental School, $e$ class. The course was based on Powerpoin presentations online, notes, quizzes, links to relevant websites and discussion forums. multimedia CD improved the students' capability of visualize and interpret errors in oral radiographs.

Students who received an interactive CAI CD before exposing their initial full series of radiographs made more errors than those students who did not receive the CAI CD. However, those students who received the CAI CD preferred reviewing the $C D$ and recommended the $\mathrm{CA}$ CD to others.

Concerning student performance, students in blended group performed significantly better in the

knowledge post-test than their colleagues group. Students also group. Students also evaluated the cours
component in a positive way. 
Meckfessel

et al, $2011^{30}$

Germany

Software "Medical Schoolbook" for creating dynamic websites. Eight $X$-ray equipment for radiography, radiation protection, physical

basis, interactive-

learning module, various

radiographic techniques and X-ray examination of tooth and mandibular

$$
\text { fractures. }
$$

\section{Nkenke et Germany} al, $2012^{31}$

Medlearn Online platform. The learning content comprised radiation physics, $X$-ray production, X-ray teractions, radiation dose, imaging equipment, radiation
protection, image creation, and norma radiological anatomy of the teeth and jaws. the dental radiology ectures and leads to significantly bette outcome in final examinations.

face-to-face lectures the basis for education at university, although the
rated the e-learning rated the e-learning course positively. They were significantly less

confident in being when compared to the

traditional group.
E-learning is appreciated in the student body and leads to significantly better test scores in inal examinations. Well designed programs are set to establish online courseware as an essential part in

$$
\text { education. }
$$

Students using technology-enhanced learning performed comparable to their counterparts who attended traditional face-to-face lectures. Technology-enhanced learning in a

theoretical radiological science course has the potential to reduce the need for the faceto-face lectures. However, it cannot replace traditional education. Instead, it allows combining eallows combining eface lectures at the best convenience of the students. 


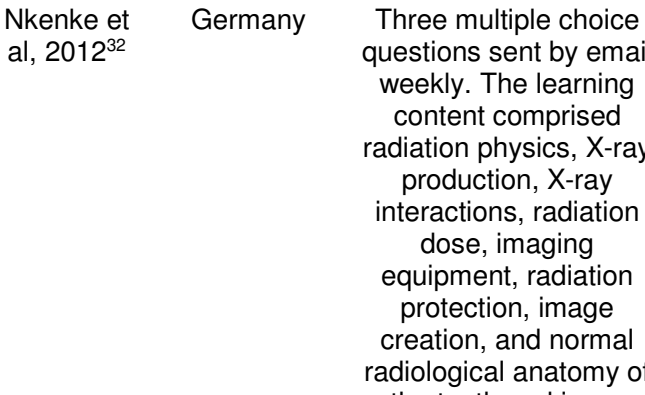

the teeth and jaws. page with theoretical and practical points to be studied. In the theoretical section, the bisecting-angle

technique for periapical radiographs for different regions is presented in the form of concise texts d graphic images aid student understanding. sessions that include the earning of anatomic aspects of the craniofacial complex, the identification of
The members of the spaced education group rated the didatics of the

course significantly

of the traditional group and they were positive bout receiving multiple choice questions via email and getting

explanation on the correct answers via

mail later on.

Adding spaced education to a face-toface theoretical radiological science course signilicantly activates students in a way that they spend more time on keeping busy with the learning content. Moreover, combining spaced education with face-toface lectures gives a view to a more
balanced way of education that does not prefer specific learning styles.

Virtual teaching was efficient in promoting the comprehension and raining of the bisectingangle technique for periapical radiographs. Students that used the application accepted it well, and their number of correct answers was corifect answers that of the control group. This study demonstrated that the difficulties inherent to the learning and performance of the bisecting-angle riapical radiograph

might be overcome by using intorive by using interactive computer-aided teaching, which promotes better understanding and virtual training of the procedure under study. n Computer-aided learning produced better results than conventional education.
LVO was shown to be a useful and efficient tool for learning 
landmarks, and the interpretations of cephalometric measurements with didactic, interative, simple animation, an self-assessment

$$
\text { components. }
$$

\begin{abstract}
Tan et al, United
$2009^{35}$

Kingdom

E-content in radiological

science, including

radiation physics and

principles of radiation
\end{abstract}

protection.
A 100 percent e-learning

cquivalent learning

outcomes as those

achieved with the

didactic lectures. Simply

put, the replacement of

traditional face-to-face

lectures with e-learning

in this case study did not

compromise the learning

outcomes of Year 1

radiological science

students.
Whereas faculty may have mixed feelings about the

transformation, the

receptive attitudes of students as well as the advantages that can be gained without compromising the quality of learning could drive e-learning forward for popular courses in higher education such as dentistry.

\section{${ }^{*}$ All Undergraduate Students}


Table 3: Methodological Appraisal of Selected Studies Based on Methodological Index for non-randomized studies (MINORS). ${ }^{22}$

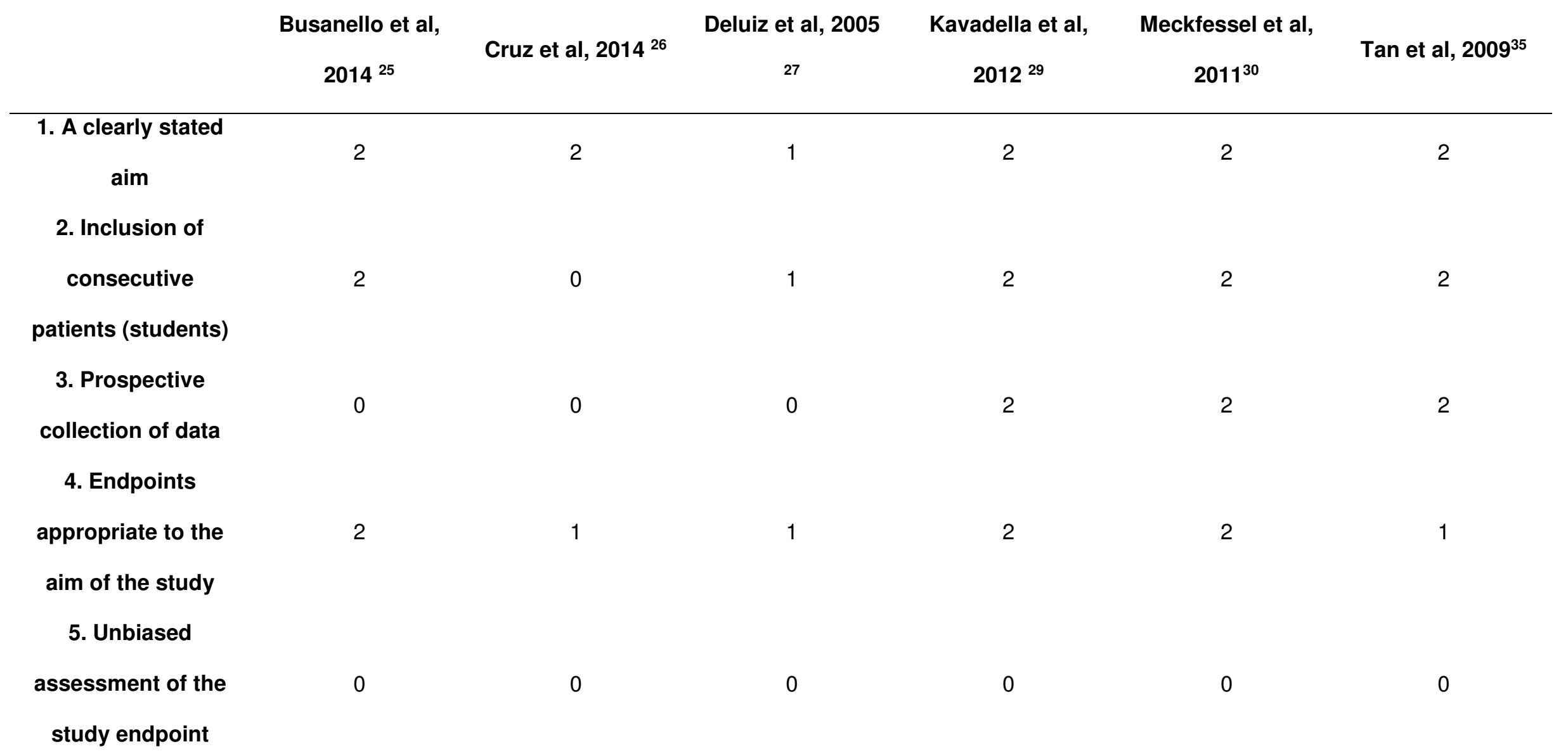




\section{Follow-up period}

appropriate to the

aim of the study

\section{Loss to follow up}

less than $5 \%$

8. Prospective

calculation of the

0

study size

Additional criteria in the case of comparative study

\begin{tabular}{|c|c|c|c|c|c|c|}
\hline $\begin{array}{l}\text { 9. An adequate } \\
\text { control group }\end{array}$ & 2 & 1 & 2 & 2 & 2 & 1 \\
\hline $\begin{array}{l}\text { 10. Contemporary } \\
\text { groups }\end{array}$ & 2 & 1 & 2 & 2 & 0 & 1 \\
\hline 11. Baseline & & & & & & \\
\hline $\begin{array}{c}\text { equivalence of } \\
\text { groups }\end{array}$ & 2 & 1 & 2 & 2 & 1 & 0 \\
\hline $\begin{array}{c}\text { 12. Adequate } \\
\text { statistical analyses }\end{array}$ & 2 & 1 & 1 & 2 & 1 & 1 \\
\hline
\end{tabular}




\section{Total Score}

The items are scored 0 (not reported), 1 (reported but inadequate) or 2 (reported and adequate). The global ideal score being 16 for non-comparative studies and 24 for comparative studies. 
Table 4. The Cochrane Collaboration's tool for assessing risk of bias in randomised trials. ${ }^{23}$

Howerton et al, 2002 ${ }^{28} \quad$ Nkenke et al, 2012 ${ }^{31} \quad$ Nkenke et al, 2012 $\quad$ Silveira et al, 2008 $\quad$ Silveira et al, $2009^{34}$

\begin{tabular}{|c|c|c|c|c|c|}
\hline $\begin{array}{l}\text { 1. Random sequence } \\
\text { generation (selection } \\
\text { bias) }\end{array}$ & Low & Low & Low & High & High \\
\hline $\begin{array}{l}\text { 2. Allocation } \\
\text { concealment (selection } \\
\text { bias) }\end{array}$ & Low & Low & Low & High & High \\
\hline $\begin{array}{l}\text { 3. Blinding of } \\
\text { participants and } \\
\text { researchers } \\
\text { (performance bias) }\end{array}$ & Unclear & Unclear & Unclear & Low & Unclear \\
\hline $\begin{array}{l}\text { 4. Blinding of outcome } \\
\text { assessment (detection } \\
\text { bias) }\end{array}$ & Unclear & Unclear & Unclear & Low & Unclear \\
\hline 5. Incomplete outcome & Low & Low & Low & Unclear & Unclear \\
\hline
\end{tabular}




\section{APÊNDICE 2 - AUGMENTED REALITY AS A NEW PERSPECTIVE IN DENTISTRY: DEVELOPMENT OF A COMPLEMENTARY TOOL}

\section{Augmented reality as a new perspective in dentistry: development of a complementary tool.}

\section{Realidade aumentada como uma nova perspectiva em Odontologia:}

\section{desenvolvimento de uma ferramenta complementar.}

How Augmented Reality can provide new possibilities of visualizing image exams.

Como a Realidade Aumentada pode fornecer novas possibilidades de visualização de exames por imagem.

Glaucia N M Santos, Ms*, Everton L S da Rosa, PhD**, André F Leite, PhD*, Paulo T de S Figueiredo, $\mathrm{PhD}^{*}$ and Nilce $\mathrm{S}$ de Melo, $\mathrm{PhD}^{*}$.

*Department of Dentistry, Health Sciences Faculty, University of Brasília, Brasília, Brazil;

${ }^{* *}$ Oral and maxillofacial surgeon of Hospital de Base of Federal District, Brazil.

\section{ABSTRACT}

The purpose of this study is to introduce a visualization and interaction tool of Augmented Reality in mobile devices using three-dimensional (3D) volumetric images from patients' real tomographic acquisition, and to describe the steps for preparing the models for such 3D visualizations. Augmented Reality was built correlating tomographic images and open-source software, in a sequence of (1) Image acquired, that consists of multi-planar images that can be visualized as 3D renderings and are the basis for constructing polygonal surfaces of specific anatomic structures of interest, (2) Creation of volumetric models, in which 3D volumetric model can be saved and exported as a 3D polygonal mesh in .stl file format, (3) Model simplification, which must be done in order to simplify the matrix of polygonal surfaces, and reduce models' megabytes, and (4) Create the augmented reality project. Once these procedures are performed, the Augmented Reality project can be saved and visualized in mobile devices. The volumetric model from a computed tomography acquisition is available in 
any mobile device screen, superimposed on a marker. This approach facilitates the visualization of the model, giving the precise location of structures and abnormalities, as supernumerary teeth, bone fractures and asymmetries. Also, the model is saved for future and multiple visualization. Augmented Reality application is a new perspective in dentistry although it is in an early phase. It can be created by integrating multiple technologies and has a great potential to support learning and teaching, and improve how 3D models from medical images are seen.

Keywords: augmented reality; dentistry; digital image; education; radiology.

\section{INTRODUCTION}

Nowadays, one of the most relevant technological tools available in our information-driven society is augmented reality, which has been developed and applied in several fields such as architecture, advertising, archeology, marketing, military and leisure, and also has a promising future in health sciences, including dentistry, especially in oral and maxillofacial surgery, orthodontics, oral radiology and dentistry education. ${ }^{1,2}$ Augmented Reality (AR) can be defined as enhancing an individual's visual experience with the real world through the integration of digital visual elements. It is characterized by a combination of real and virtual scenes registered in three dimensions, with the possibility of interaction in real time. Therefore, an augmented reality environment allows the user to see the real world with virtual computer-generated objects superimposed or merged with real surroundings. ${ }^{3-6}$

The advent of Computed Tomography (CT) and magnetic resonance imaging (MRI), also referred to as nuclear magnetic resonance imaging (NMRI) or magnetic resonance tomography (MRT), enabled the acquisition of Three-Dimensional (3D) volumetric images of a patient's body, created from the multi-planar images in DICOM (Digital Imaging and Communications in Medicine) format. Volumetric models are obtained and usually visualized and manipulated in specific DICOMreader software. ${ }^{7}$ In dentistry, the use of Cone Beam Computed Tomography (CBCT) is well defined, particularly for tooth localization, facial asymmetries, fractures and pathology diagnosis. ${ }^{8,} 9$ More effective and rational clinical decision-making for orthodontic and orthognathic surgery patients, for example, requires careful 3D image analysis techniques. ${ }^{10}$ The idea of integrating patients' volumetric models and AR can contribute to faster and easier visualization of abnormalities, localizations and 
anatomic points of interest. ${ }^{11}$ Mobile devices, particularly smartphones and tablet devices, are an ideal platform for AR technology.

In addition, learning based on performing experiments and further reflection on their results is the basis of experiential learning, widely used in dentistry, as it is partially a practice training course. A key determinant of the effectiveness of experiential learning is interactivity. ${ }^{12}$ As far as learning content is concerned, interactivity is defined as: "the extent to which users can participate in modifying the form and content of a mediated environment in real time". ${ }^{13}$ One of the most promising technologies is augmented reality, as the coexistence of virtual objects and real environments allows individuals to visualize complex spatial relationships and abstract concepts, and interact with two- and three-dimensional synthetic objects in the mixed reality. ${ }^{14}$ It has been demonstrated that virtual learning applications may provide adequate tools that allow users to learn in a quick and efficient way, interacting with virtual environments. ${ }^{15}$

This article introduces a modern visualization and interaction tool of $A R$ in mobile devices using 3D volumetric images from patients' real tomographic acquisition, and describes the steps for preparing the models for such 3D visualizations. Also, to provide insights into opportunities offered by $A R$, the purpose of this article is to present the advantages, challenges and perspectives of $A R$ in dentistry.

\section{MATERIALS AND METHODS}

AR using tomographic volumetric models can be built by following these steps (Figure 1): (1) Import or access previously acquired image, (2) creation of volumetric models, (3) model simplification, and (4) Create the augmented reality project. Once these procedures have been carried out, the AR project can be saved and visualized in mobile devices.

In order to prepare 3D volumes, data coming from CBCT image acquisition will be described, since it is widely used in dentistry. A CBCT scan in DICOM format with a protocol of choice can be used, regarding Field-Of-View (FOV) and slice thickness. These multi-planar images can be visualized as 3D renderings and are the basis for constructing polygonal meshes or surfaces of specific anatomic structures of interest. 
In this study, the DICOM module, in 3D Slicer software, an open-source tool, is used to open and visualize the CBCT scan images in DICOM format. ${ }^{16}$ For this purpose, a notebook with the following specification was used: Intel Inside ${ }^{\text {TM }}$ Core i7, 16 GB RAM memory and 2 GB off-board video card. Firstly, in the Volume Rendering module, the 3D model is displayed. The preset CT-Bone is selected and, in the Shift option, only hard tissues are chosen to be shown. It is also possible to crop the image in the desirable Region Of Interest (ROI). The Editor module is used to obtain a 3D representation of the hard and soft tissues in order to perform the Image Segmentation through the Thresholding tool. This is useful for identifying and delineating the anatomic structures of interest in the CBCT scan, which results in the $3 \mathrm{D}$ volumetric label map files. Thresholding classifies a voxel (element of volume in 3D image) depending only on its intensity. ${ }^{17} \mathrm{~A}$ certain intensity range is specified with lower and upper threshold values. Each voxel belongs to the selected class (bone, for example) if, and only if, its intensity level is within the specified range. The appropriate value range has to be selected for each patient since bone density varies between patients and intensity values of bone can vary between scanners. ${ }^{10}$ After segmentation, the 3D volumetric model is created from the label map, by clicking the Model button, then it can be saved and exported as a 3D triangular or polygonal mesh (3D surface model), in .stl (STereoLithography) file format.

The next step is model simplification, aimed at simplifying the matrix of polygonal meshes, which is important for reducing models' megabytes. For this procedure, MeshLab ${ }^{18}$ open-source software is used. In this software, the models can have their megabytes reduced while the quality is well maintained in Filters $>$ Remeshing, Simplification and Reconstruction $>$ Quadric Edge Collapse Decimation. Also, in models from CBCT acquisition, there is a lot of noise and many artefacts that can be removed manually in Edit>Select Faces in a Rectangular Region (select in red the undesirable faces) and pressing Delete. After, the conversion of the .stl format into a volumetric format such as .obj or .fbx (FilmBoX) file can be done either to digital dental models or digitized dental plaster models. Once their format acquisition is .stl, they are simplified to a smaller file size and converted to .obj or .fbx volumetric format. The model simplification can be done in any modelling and rendering software, such as Autodesk ${ }^{\circledR} 3 \mathrm{ds}$ Max ${ }^{\circledR 19}$ or Blender 3D. ${ }^{20}$ 
The development of the augmented reality project is done in the Metaio Creator $^{21}$ AR software. There is an open-source version of this software that allows the creation of $A R$ scenarios in a trackable (tracking references), using 3D models in .fbx or .obj formats. When developing the project, a simple and easy .jpeg (Joint Photographics Experts Group) image in high definition is used as the basis of the project (trackable), and the model is well positioned over it, observing the three axes for adequate location. Afterwards, this image is used as the marker. Animations, colours, shelter and written texts can be added to the model. As the project is saved, the software uploads the AR content to a cloud account and provides a Quick Response (QR) code of the project that is scanned by the free app JUNAIO ${ }^{22}$, previously downloaded in any mobile device.

\section{RESULTS}

An easy and quick way to visualize 3D models from medical imaging is available on mobile devices using AR technology (Figure 2). First, the JUNAIO free app must be downloaded onto a device, such as smartphones and tablets. Secondly, the device must be connected to the Internet, so the $(Q R)$ code is scanned by the app. The QR code may be printed, or scanned from a computer monitor or a mobile device screen. Third, the mobile device screen is pointed to the marker, which must be the same image used as the trackable (tracking reference) in the development of the AR project. Like the QR code, this marker may be printed or displayed on a screen or monitor.

The volumetric model is then available on the mobile device screen, superimposed on the marker. The observer has the opportunity to interact with the model, turning it sideways or zooming by touching the screen. This approach facilitates the visualization of the model, giving the precise location of structures and abnormalities, such as supernumerary teeth, bone fractures and asymmetries. Also, the model is saved for future and multiple visualization. In our study, the AR technology was successfully used as part of a pilot distance course in oral radiology in Moodle platform (Figure 3), where clinical cases with radiographic and tomographic images, and $3 \mathrm{D}$ models with AR technology were presented to students in order to turn their learning easier and more attractive.

\section{DISCUSSION}


Although the usage of AR in a pilot distance course in oral radiology was successful, it leads to discussions about some of the benefits and drawbacks of the technology. The advantages of AR can be classified into two parts: the advantages of AR application and the advantages in the AR creation phase. Using an AR application enables the simulation, visualization and addition of information, and interaction with virtual objects without being totally immersed in virtual life. ${ }^{23}$ In a regular or distance educational context, for example, the coexistence of virtual objects and real environments allows learners to visualize complex spatial relationships and abstract concepts, ${ }^{14}$ experience phenomena that cannot be experienced in the real world ${ }^{5}$, interact with two- and three-dimensional synthetic objects in the mixed reality ${ }^{24}$ and develop important practices and literacies that cannot be developed and enacted in other technology-enhanced learning environments. ${ }^{25}$ In this way, AR technology can provide synthetic objects for teaching, such as anatomical parts or rare items for science laboratories. Kotranza et al. (2009) ${ }^{26}$ showed an AR system in clinical medicine that embedded touch sensors in a physical environment, collected sensor data to measure learners' performances and then transformed the performance data into visual feedback.

By using this AR system, learners could receive real-time, in situ responses that may help improve their performances and enhance their psychomotor skills in a cognitive task. Rhienmora et al. (2010)27 developed an AR dental training simulator utilizing a haptic (force-feedback) device. A number of dental procedures such as crown preparation and opening access to the pulp can be simulated with various shapes of dental drill. The system allows students to practise surgery in the correct postures as in the actual environment by combining 3D tooth and tool models in the real-world view and displaying the result through a video see-through headmounted display. Qu et al. (2015) ${ }^{28}$ presented a navigation technique that can display $3 \mathrm{D}$ images of the mandible with a designed cutting plane on surgical sites, based on AR, by providing a surgical guide for the transfer of the osteotomy lines and the positions of the screws. Espejo-Trung et al. (2015) ${ }^{29}$ developed a new learning object based on AR models in order to teach preparation design of gold onlay at a dental school in Brazil with a high index of acceptance among students. 
Publishing companies of health articles and book chapters can have their publication experience enhanced when providing AR 3D volumes for worldwide readers, as printed pages limit the number of images displayed and they are only seen in 2D version. With AR technology, volumes are easily accessed by readers on their own tablet or mobile phone, by scanning QR codes.

The AR creation process is less expensive than that of virtual reality (VR); this is considered one of the most important advantages of AR. This process can be done on any computer or notebook with a 2 GB off-board video card and 8 GB RAM memory or more, using free software. In addition, the models can be visualized and easily manipulated on any mobile device with default settings.

It is important to bear in mind that for the construction of 3D volumes, the patient's examination already requested by the dentist or physician is used. In order to prepare $3 \mathrm{D}$ volumes, data coming from different imaging modalities can be used, such as images from CBCT, CT and MRI, or digital dental models. The same image processes are applicable and can be generalized for images acquired with any 3D imaging modality, except digital dental models and digitized plaster dental models, which are acquired in .stl extension instead of DICOM. DICOM files can be opened and visualized in any 3D image analysis software of choice.

Until now, the drawbacks of AR have been some weak points in the technology starting from the time consumption, rendering quality and storage in cloud space.

The time consumption is an important disadvantage related to the $A R$ creation process due to the time spent eliminating the artefacts from the $3 \mathrm{D}$ model in a rendering software. $\mathrm{CBCT}$ images show more noise than multislice $\mathrm{CT}$ images, and the presence of metal parts enhances the artefacts. Another obstacle is the need to learn how to use a variety of software, one for each step. Depending on the computer configuration, the rendering time may be too long and the quality may not be ideal. Despite the time spent, once the model is ready it can be displayed many times for many people all around the world.

In terms of rendering quality, the main limitation of thresholding is that it is artefact-prone. These artefacts are created because different densities within a voxel are averaged and then represented by a single CBCT number. Therefore, the CBCT 
numbers of thin bony walls will tend to drop below the thresholding range of bone because their density is averaged with that of the surrounding air. This effect causes artificial holes in 3D reconstructions. ${ }^{30}$ In a mandible, which presents thick and dense bone, the segmentation works well. However, it fails for thin bones as the condyles and labial surfaces of the teeth. So, the morphology and position of the condyles and internal surfaces of the ramus and maxilla are critical for diagnosis, which requires a careful segmentation. Another source of artefacts is the presence of metallic material in the face (orthodontic appliances, dental fillings, implants, surgical plates). Metal artefact intensity values fall into the thresholding range of bone and are included in CBCT images as pronounced "star-like" streaks. There is no standard segmentation method that works equally well for all software. ${ }^{10}$ Regarding CBCT images, the 3D models quality may be influenced by several parameters such as scan field, voxel size and segmentation threshold selections. The previous studies recommend the use of small scan fields and a small voxel size to optimize quality of 3D model. ${ }^{31,32}$

The greatest disadvantage of the AR creation process is the storage in cloud space. Using an open-source software, the space is limited to $100 \mathrm{MB}$. This limitation hinders the creation of more sophisticated models, since models from DICOM files are heavy even after the simplification step. Partnerships with commercial AR software can increase the quality of the models and add possibilities such as changing colours and including animations.

\section{CONCLUSION}

As has been shown, AR application is a new perspective in dentistry although it is in an early phase. It can be created by integrating multiple technologies and has great potential to support learning and teaching, and improve how 3D models from medical images are seen. Further studies are necessary to develop easier ways to create the volumes and make the best use of them in dentistry, including in educational and commercial environments.

\section{Acknowledgements}

This work acknowledges the support received from Visualization, Interaction and Simulation Laboratory (L-VIS) of the University of Brasília in the development of Augmented Reality projects. 
Conflict of Interest: None.

Funding: This research was conducted without funding support.

\section{REFERENCES}

1. Craig A. Augmented reality applications Understanding augmented reality. Boston: Morgan Kaufmann; 2013. p. 221-54.

2. Martín-Gutiérrez J, Fabiani P, Benesova W, Meneses M, Mora C. Augmented reality to promote collaborative and autonomous learning in higher education. Computers in Human Behavior. 2015;51:752-61.

3. Abe $Y$, Sato S, Kato K, Hyakumachi T, Yanagibashi Y, Ito M, et al. A novel 3D guidance system using augmented reality for percutaneous vertebroplasty. Journal of Neurosurgical Spine. 2013;19(4):492-501.

4. Bronack S. The role of immersive media in online education. The Journal of Continuing Higher Education. 2011;59(2):113-7.

5. Klopfer E, Squire K. Environmental detectives: the development of an augmented reality platform for environmental simulations. Educational Technology Research and Development. 2008;56(2):203-28.

6. Azuma R. A survey of augmented reality presence: teleoperators and virtual reality. Environments. 1997;6(4):355-85.

7. Graham R, Perriss R, Scarsbrook A. DICOM demystified: a review of digital file formats and their use in radiological practice. Clinical radiology. 2005;60:1133-40.

8. Scarfe W, Farman A, Sukovic P. Clinical Applications of Cone-Beam Computed Tomography in Dental Practice Journal of the Canadian Dental Association. 2006;72(1):75-80.

9. Macleod I, Heath N. Cone-Beam Computed Tomography (CBCT) in Dental Practice. Dental Update. 2008;35:590-8.

10. Cevidanes L, Ruellas A, Jomier J, Nguyen T, Pieper S, Budin F, et al. Incorporating 3-dimensional models in online articles. American journal of orthodontics and dentofacial orthopedics. 2015;147(5 (Suppl)):S195-204.

11. Kawamata A, Ariji $\mathrm{Y}$, Langlais $\mathrm{R}$. Three-dimensional computed tomography imaging in dentistry. Dental Clinics of North America. 2000;44:395-410. 
12. Roussou M. Learning by doing and learning through play: an exploration of interactivity in virtual environments for children. ACM Journal of Computers in Entertainment. 2004;1(2).

13. Steuer J. Defining virtual reality: dimensions determining telepresence. Journal of Communication. 1992;42(4):73-93.

14. Arvanitis T, Petrou A, Knight J, Savas S, Sotiriou S, Gargalakos M, et al. Human factors and qualitative pedagogical evaluation of a mobile augmented reality system for science education used by learners with physical disabilities Personal and Ubiquitous Computing. 2009;13(3):243-50.

15. Pan Z, Cheok A, Yang H, Zhu J, Shi J. Virtual reality and mixed reality for virtual learning environments Computers and Graphics. 2006;30(1):20-8.

16. 3DSlicer. 3D Slicer. Available at: http://www.slicer.org: 3Dslicer.org; 2015 [cited 2015 October 28].

17. Chapuis J. Computer-Aided Cranio-Maxillofacial Surgery. Swiss: University of Bern; 2006.

18. MeshLab. MeshLab Available at: http://meshlab.sourceforge.net. 2015 [cited 2015 November 11].

19. 3dsMax. Autodesk 3ds Max. Available at: http://www.autodesk.com.br/products/3ds-max/overview.: autodesk.com.br. 2015 [cited 2015 October 15].

20. 3DBlender. Home of the Blender Project. Available at: https://www.blender.org/:: blender.org; 2015 [cited 2015 October 23].

21. MetaioCreator. Metaio The Augmented Reality Company. Available at: https://www.metaio.com/ 2015 [cited 2015 October 17].

22. Metaio. Metaio releases junaio 2.0 for App Store. In: Metaio, editor. junaio-20now-in-the-app-store-next-generation-ar-browser/ Metaio; 2010.

23. Diggins D. ARLib: A Cpp augmented reality software development kit. United Kingdom: Bournemouth University; 2005.

24. Kerawalla L, Luckin R, Seljeflot S, Woolard A. "Making it real": exploring the potential of augmented reality for teaching primary school science. Virtual Reality. 2006;10(3):163-74. 
25. Squire K, Jan M. Mad city mystery: developing scientific argumentation skills with a place-based augmented reality game on handheld computers. Journal of Science Education and Technology. 2007;16(1):5-29.

26. Kotranza A, Lind D, Pugh C, Lok B. Real-time in-situ visual feedback of task performance in mixed environments for learning joint psychomotor-cognitive tasks Paper presented at the 8th IEEE international symposium on mixed and augmented reality (ISMAR), Orlando, FL 1109/ISMAR20095336485. 2009:125-34.

27. Rhienmora P, Gajananan K, Haddawy P, Dailey M, Suebnukarn S. Augmented reality haptics system for dental surgical skills training VRST '10 Proceedings of the 17th ACM Symposium on Virtual Reality Software and Technology ACM 2010. 2010:97-8.

28. Qu M, Hou Y, Xu Y, Shen C, Zhu M, Xie L, et al. Precise positioning of an intraoral distractor using augmented reality in patients with hemifacial microsomia Journal of Cranio-Maxillo-Facial Surgery. 2015;43:106-12.

29. Espejo-Trung LC, Elian SN, Luz MAAC. Development and Application of a New Learning Object for Teaching Operative Dentistry Using Augmented Reality. Journal of Dental Education. 2015;79(11):1356-62.

30. Hemmy D, Tessier P. CT of dry skulls with craniofacial deformities: accuracy of three-dimensional reconstruction. Radiology 1985;157(1):113-6.

31. Hassan B, Souza PC, Jacobs R, Berti SA, van der Stelt P. Influence of scanning and reconstruction parameters on quality of three-dimensional surface models of the dental arches from cone beam computed tomography. Clinical Oral Investigation. 2010;14(3):303-10.

32. Matta RE, von Wilmowsky C, Neuhuber W, Lell M, Neukam FW, Adler W, et al. The impact of different cone beam computed tomography and multi-slice computed tomography scan parameters on virtual three-dimensional model accuracy using a highly precise ex vivo evaluation method. Journal of Craniomaxillofacial Surgery. 2016;44(5):632-6. 
Corresponding author

Glaucia Nize Martins Santos

SQN 403, bloco O apto 101, Asa Norte, Brasília, DF, Brazil

Post code: 70835150

e-mail: nize.gal@gmail.com

tel: $+556199113-8119 \quad$ fax: $+55613326-3265$

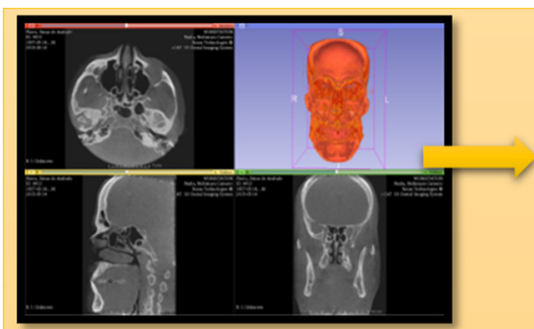

(1) image acquisition

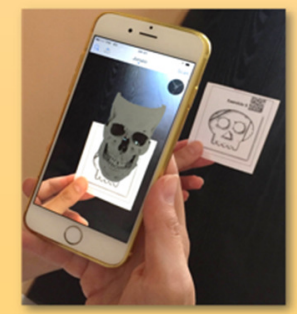

(5) AR visualization in Junaio app

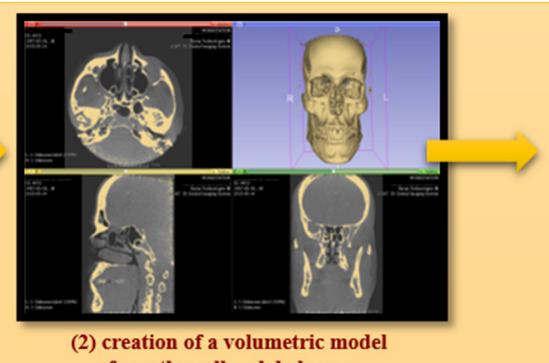

from the yellow label map

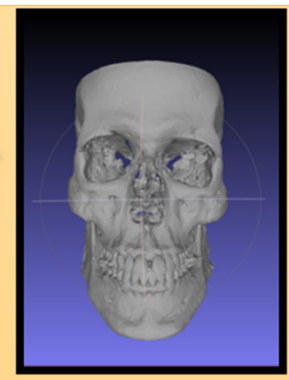

(3) model simplification

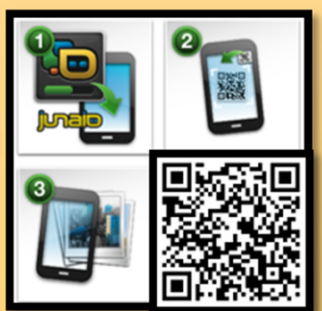

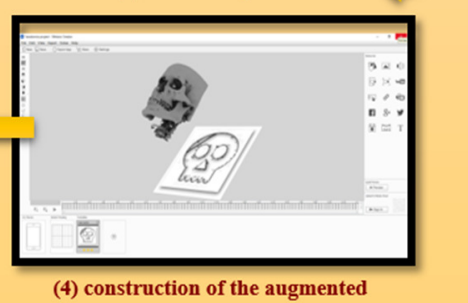

reality project

Figure 1. (1) Image acquisition from a CBCT scan in Dicomreader Slicer 3D. (2) In Slicer 3D, the 3D model is created from the label map and then it is saved and exported as a 3D triangular or polygonal mesh in .stl file format. (3) In the model simplification step, the model has its megabytes reduced while the quality is well maintained in MeshLab software. (4) The creation of the augmented reality project is done in the Metaio Creator AR software. (5) AR visualization in Junaio app. 


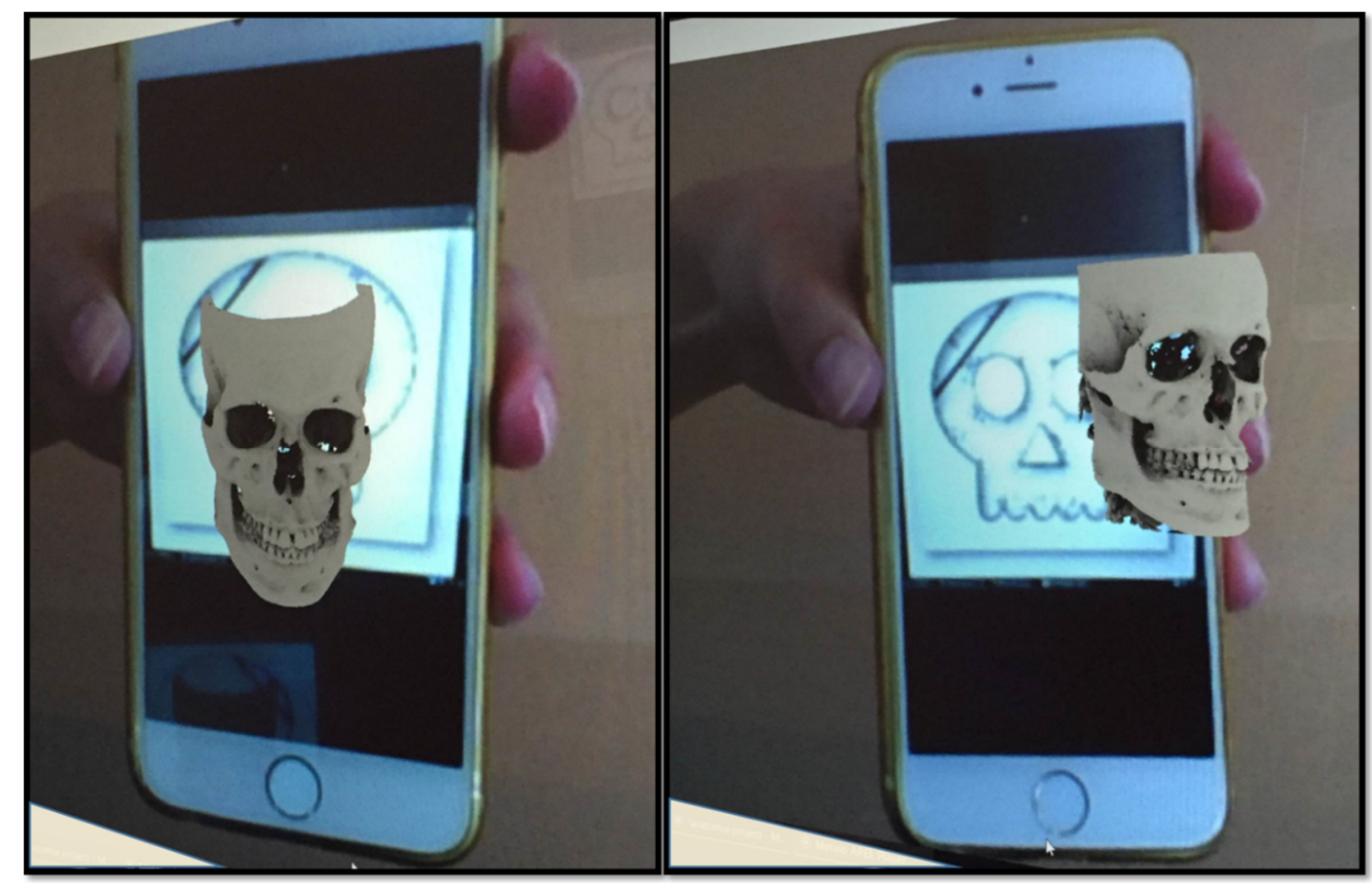

Figure 2. Visualization of a $3 \mathrm{D}$ model from a CBCT scan using the AR technology in a smartphone screen.

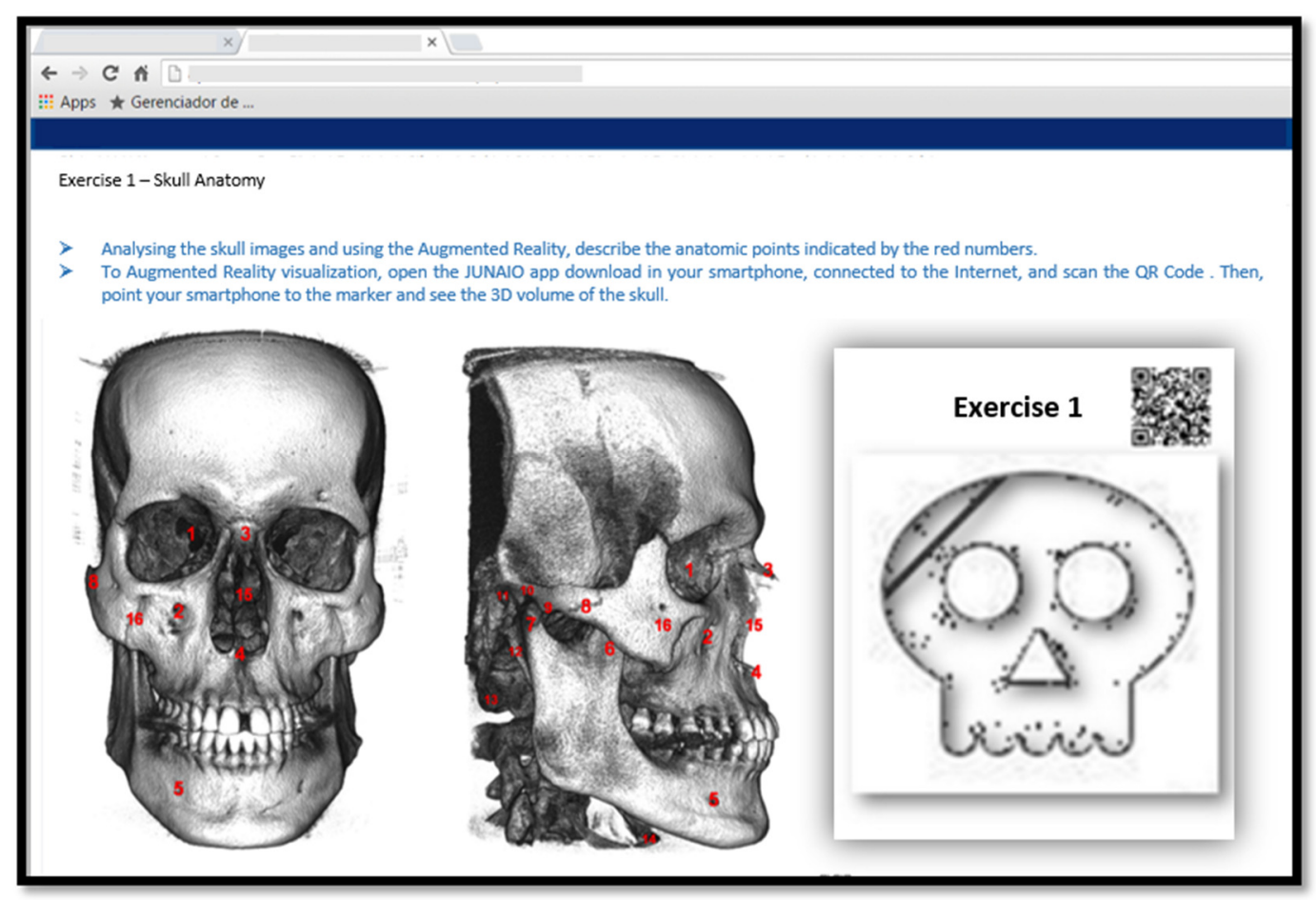

Figure 3. AR technology applied to a pilot project of distance education in oral radiology using Moodle platform. 


\section{APÊNDICE 3: METOdOlOGIAS DE ENSINO EM DIAGNÓSTICO BUCAL. UMA EXPERIÊNCIA NA UNIVERSIDADE DE BRASÍLIA}

\section{E-learning em Diagnóstico Bucal: relato de experiência na Universidade de Brasília.}

E-learning in Oral Diagnosis: experience report at the University of Brasília.

Brendda Juliana Carvalho Feitosa. ${ }^{1}$

Nilce Santos de Melo. ${ }^{2}$

Gláucia Nize Martins Santos. ${ }^{3}$

${ }^{1}$ Aluna de Graduação em Odontologia da Universidade de Brasília.

2 Professora do Departamento de Odontologia da Faculdade de Ciências da Saúde da Universidade de Brasília (UnB).

${ }^{3}$ Mestranda em Ciências da Saúde da Universidade de Brasília.

\section{Resumo}

Define-se e-learning como qualquer tipo de situação educacional em que o conteúdo é disponibilizado eletronicamente via Internet quando e onde as pessoas precisam. Usando as possibilidades que o ambiente virtual oferece para o ensino, foi elaborado um e-módulo na Plataforma Moodle. O objetivo desse estudo foi verificar o acesso, desempenho e aceitação de alunos de graduação em Odontologia frente à utilização do e-módulo nas atividades online da Disciplina de Diagnóstico Bucal na Universidade de Brasília. Avaliações de conteúdo (pré e pós-teste), pré-teste de expectativa e pósteste de satisfação foram elaborados para avaliar o conteúdo e a aceitação do emódulo entre os participantes. Dos 25 participantes iniciais, dois concluíram o emódulo, 11 começaram e não concluíram, nove não acessaram a Plataforma e três não aceitaram responder o pós-teste de satisfação. Pré e pós-teste de conteúdo não apresentaram dados significativos. O pós-teste de satisfação mostrou que dos alunos que não acessaram o e-módulo, ou acessaram e não concluíram, 80\% alegaram "não ter tempo para acessar a Plataforma" e 15\% afirmaram não participar, ou não concluir o e-módulo "porque este não trazia acréscimo de crédito ou nota". Em conclusão, 
apesar de os alunos serem positivos em relação ao uso de novas metodologias, a participação foi muito baixa. Já o desempenho foi similar àquele das aulas presenciais. Vários fatores influenciam a atitude dos alunos no e-módulo, incluindo o ganho de recompensas e a forma pedagógica dos conteúdos. Assim, persiste ao professor o papel motivacional e mediador entre aprendizado e mundo virtual.

\section{Descritores}

Odontologia; Radiologia; Educação à distância; Tecnologia da Informação.

\section{Introdução}

O uso dos computadores, smartphones e tablets tem proporcionado fácil acesso à Internet, permitindo diferentes formas de interação, as quais incluem informação e comunicação, por meio de hipertextos, sons e animações. ${ }^{1}$ Diante dessa realidade contemporânea é importante que os métodos educacionais incorporem o uso das Tecnologias de Informação e Comunicação (TICs), buscando uma integração entre ensino, aprendizado e tecnologias.

As TICs fornecem ferramentas que provocam a capacidade de compreensão, avaliação e reflexão do aluno. ${ }^{2}$ Uma possibilidade interessante para enfrentar os desafios da educação atual é a inclusão do e-learning no currículo de graduação, pois possibilita a fusão das atividades do ensino presencial com as experiências da educação online. ${ }^{3}$ Há várias maneiras de definir o e-learning, sendo amplamente referido como "qualquer tipo de situação educacional em que o conteúdo instrucional é disponibilizado eletronicamente via Internet quando e onde as pessoas precisam". ${ }^{4}$ A Portaria 4.059 de 10 de dezembro de 2004, do Ministério da Educação (MEC), autoriza a introdução de disciplinas no modo semipresencial em até $20 \%$ da carga horária total de cursos superiores reconhecidos. ${ }^{5}$

O modelo tradicional de ensino, centrado na figura do docente, vem sendo discutido e criticado, pelo fato de o aluno ser passivo na aquisição de conhecimento. ${ }^{6}$ O aprendizado mediado pelas TICs tem seu diferencial no envolvimento de alunos e professores, pois o aluno passa de coadjuvante a protagonista na sua formação. O papel do professor deve ser de participante do processo de ensino como um agente motivador e facilitador ${ }^{6,7} \mathrm{O}$ docente guia seus alunos por meio de fóruns e discussões. Em contrapartida, é esperado que os discentes correspondam aprofundando seus 
conhecimentos, com participação ativa e dinâmica. ${ }^{8}$ Metodologias ativas também propiciam a interação entre alunos em um ambiente de aprendizagem colaborativa, no qual se obtêm ideias mais elaboradas por meio da perspectiva do outro. ${ }^{9}$

O incentivo e a disponibilidade do professor-tutor são considerados fatores fundamentais no desempenho dos alunos. Esclarecer dúvidas quanto ao conteúdo ou quanto à estrutura do módulo, coordenar, orientar e organizar pedagogicamente são ações que vão evitar a sensação de abandono dos acadêmicos. ${ }^{10}$

Devido à necessidade de ferramentas de suporte pedagógico, surgiram os Ambientes Virtuais de Aprendizagem (AVA). Tratam-se de plataformas de ensino criadas na Internet, que usam recursos tecnológicos para criar ambientes propícios ao aprendizado e à interação entre docentes e alunos, podendo ser comerciais ou gratuitos. ${ }^{7,9}$

No presente estudo, a Plataforma Moodle (Modular Object Oriented Dynamic Learning Environment) foi escolhida para o desenvolvimento de conteúdos teóricos e práticos em Radiologia Oral. É uma opção gratuita de um AVA de uso bem consolidado em diversos departamentos da Universidade de Brasília. Proporciona educação à distância por meio da aprendizagem colaborativa e permite o bom gerenciamento do conteúdo, dos participantes, das atividades, além de outros recursos disponíveis na plataforma. ${ }^{11,12 .}$

O software escolhido permitiu a disponibilização da tecnologia de Realidade Aumentada (RA) para as atividades práticas. Por combinar elementos virtuais com o ambiente real, a RA é interativa e tem processamento em tempo real, além de ser concebida em três dimensões. A opção de RA móvel permite a visualização dos elementos gráficos de computação em aparelhos celulares dotados de conexão com a Internet. ${ }^{13}$ Quando a câmera do aparelho celular é direcionada a um objeto com marcadores, códigos ou formas reconhecidos por RA, tais elementos são substituídos por gráficos tridimensionais integrados ao ambiente real.

Nesta perspectiva, o presente estudo tem como objetivo verificar o acesso, desempenho e aceitação de alunos de graduação em Odontologia frente à utilização do e-módulo desenvolvido na Plataforma Moodle nas atividades online da Disciplina de Diagnóstico Bucal na Universidade de Brasília. 


\section{Material e Métodos}

1. Criação do módulo online de interpretação radiográfica

O e-módulo de "Princípios de interpretação radiográfica" foi desenvolvido para ser disponibilizado online, com o apoio da Diretoria de Ensino de Graduação a Distância (DEGD), da Universidade de Brasília, no âmbito da disciplina presencial de Diagnóstico Bucal. O módulo foi desenvolvido na Plataforma Moodle (aprender.unb.br), com duração de 11 semanas, por discente de pós-graduação em Ciências da Saúde.

O presente estudo foi aprovado pelo comitê de ética da Universidade de Brasília sob o número CAAE 42277115.3.0000.0030.

O prazo de uma semana foi estabelecido para resolução dos exercícios a partir do dia em que o módulo era lançado. Foi ainda disponibilizada uma tutora online para esclarecer eventuais dúvidas quanto ao conteúdo e à Plataforma. Cada módulo da disciplina era composto por apresentação teórica do conteúdo, ilustrado por radiografias catalogadas a partir dos arquivos de imagens radiográficas do Hospital Universitário de Brasília, do Hospital de Base do Distrito Federal e de arquivo pessoal, fórum de exercícios e artigos científicos disponíveis para estudo complementar. 0 enfoque do conteúdo foi sobre aspectos radiográficos de anatomia e alterações patológicas do complexo maxilofacial. A seleção do conteúdo teórico e das imagens foi baseada no roteiro de White \& Pharoah $^{14}$, que expõe a sequência de passos para fechar as hipóteses diagnósticas de lesões ósseas.

2. Criação de instrumentos pedagógicos usando a Realidade Aumentada

Cinco módulos de atividade prática de interpretação radiográfica foram ofertados, um a cada semana, sendo um sobre anatomia do crânio e os demais de casos clínicos de patologia. Cada atividade prática oferecia o recurso RA como opção de estudo de modelos tridimensionais. Para utilizar esse recurso, o aluno deveria ter um smartphone conectado à Internet e fazer o download do aplicativo gratuito JUNAIO. Ao abrir o aplicativo, deveria apontar a câmera do celular para o marcador, disponibilizado na tela do computador ou em arquivo .pdf para impressão, e assim visualizar os modelos tomográficos em RA. Não haveria prejuízo à compreensão da 
atividade se o aluno não conseguisse utilizar o recurso da RA, pois os mesmos modelos foram também expostos como fotografias em cada exercício.

3. Oferta do módulo na Plataforma Moodle

O e-módulo foi oferecido aos alunos matriculados na disciplina presencial de Diagnóstico Bucal, cuja carga horária era de 36 horas aula/ semestre, ofertada aos alunos do $4^{0}$ semestre do curso de Odontologia da Universidade de Brasília. Este serviu como material de apoio ao conteúdo presencial, disponibilizado para participação voluntária e sem acréscimo de nota ou crédito.

4. Avaliação

Consistiu da aplicação de quatro testes, sendo dois prévios ao uso do e-módulo (pré-teste de conteúdo e teste de expectativa) e os demais após o término da disciplina (pós-teste de conteúdo e teste de satisfação).

- Pré-teste (de conteúdo e expectativa)

Desenvolvido para avaliar o conhecimento e o nível de heterogeneidade da turma. Os alunos responderam a um pré-teste teórico de múltipla escolha, com dez questões sobre conteúdo de Radiologia Geral. O teste, não validado, foi elaborado sob a supervisão dos professores da disciplina de Diagnóstico Bucal. Os estudantes não tiveram acesso ao gabarito.

Os participantes também preencheram o Teste de Expectativa, com questões relativas à facilidade de uso de computadores e celulares e acesso a Internet. O teste buscou avaliar a experiência prévia dos alunos com o e-módulo e com a Plataforma Moodle. Também foram coletadas informações sobre o perfil do aluno: idade e gênero. O teste foi baseado no trabalho de Meckfessel e colaboradores. ${ }^{15}$ Esse teste foi respondido pelos 25 alunos que aceitaram participar do e-módulo.

Os testes foram aplicados presencialmente com duração média de 30 minutos. Todos os participantes assinaram o Termo de Consentimento Livre e Esclarecido.

- Pós-teste (de conteúdo e de satisfação)

O pós-teste de conteúdo foi aplicado presencialmente ao término da disciplina para os alunos que participaram da pesquisa. Consistiu de dez questões sobre o conteúdo ministrado no e-módulo com duração média de 30 minutos e os alunos não tiveram acesso ao gabarito. 
O pós-teste de satisfação buscou avaliar a opinião dos alunos frente ao uso/experiência com o e-módulo. Avaliou o interesse e a aceitação em relação à Plataforma Moodle e ao tema abordado no e-módulo. A elaboração desse teste foi baseada no estudo de Nkenke e colaboradores. ${ }^{16}$

Os estudantes foram divididos em três grupos, sendo Grupo A aqueles que não acessaram o e-módulo; Grupo B aqueles que iniciaram o e-módulo online, mas não concluíram; e Grupo $\mathrm{C}$ aqueles que participaram do e-módulo até o final. Para cada grupo foi elaborado um tipo de teste de satisfação. O objetivo foi obter, através dos questionários personalizados para cada grupo, informações sobre a adesão e as opiniões quanto ao Moodle e ao e-módulo. Ao final do pós-teste de expectativa de cada grupo, os alunos tinham um espaço para críticas e sugestões a respeito do emódulo. Os resultados dos testes não computaram para a nota final dos participantes.

\section{Resultados}

Dos 26 alunos matriculados na disciplina presencial, 25 aceitaram participar do e-módulo. O pré-teste de conteúdo mostrou heterogeneidade da turma, com nota mínima de 3,0 e máxima de 9,0. A média foi de 6,73 e o desvio padrão de 2,089. O pós-teste de conteúdo foi respondido pelos alunos que chegaram até o final da pesquisa (dois participantes). Um aluno apresentou nota 6,0, e o outro, nota 8,0. Média das notas, 7,0.

O pré-teste de expectativa mostrou o perfil dos estudantes e foi respondido por 25 participantes. Todos afirmaram possuir celular do tipo smartphone, 96\% possuíam computador próprio com acesso à Internet e 60\% afirmaram gostar de trabalhar em computador. Com relação à Plataforma Moodle, o pré-teste de expectativa mostrou que $96 \%$ dos alunos já a haviam utilizado e $64 \%$ classificaram a Plataforma como "boa". Todos afirmaram que gostariam que a universidade ofertasse mais conteúdos via Internet.

Dos 25 alunos que participaram da pesquisa inicialmente, 22 responderam o pós-teste de satisfação e foram divididos em grupos A, B e C segundo o acesso ao emódulo. Não acessaram o e-módulo no Moodle nove participantes (Grupo A), 11 começaram e não concluíram (Grupo B) e dois participaram até o final (Grupo C). 
No pós-teste de satisfação os alunos poderiam escolher mais de uma afirmativa que justificasse sua não participação no e-módulo. O pós-teste aplicado ao Grupo $\mathrm{A}$ (participantes que não acessaram o e-módulo), mostrou que $88,8 \%$ dos alunos afirmaram não participar do e-módulo porque "não tiveram tempo para acessar a Plataforma Moodle." As demais opções do pós-teste estão expostas na tabela 1.

Tabela 1. Pós-teste de satisfação. Grupo A: Participantes que não acessaram o e-módulo. (9 alunos)

\begin{tabular}{|l|c|c|}
\hline \multicolumn{1}{|c|}{$\begin{array}{c}\text { Não participei da Disciplina de E-learning em } \\
\text { Diagnóstico Bucal porque: (marque quantas } \\
\text { alternativas forem adequadas) }\end{array}$} & N & $\%$ \\
\hline $\begin{array}{l}\text { Não tive tempo de acessar a Plataforma Moodle. } \\
\text { O tema abordado não era do meu interesse. (Princípios de } \\
\text { Interpretação radiográfica de lesões ósseas). }\end{array}$ & 1 & $11,1 \%$ \\
A participação no Moodle não trazia acréscimo de nota ou crédito. & 2 & $22,22 \%$ \\
$\begin{array}{l}\text { Somente o conteúdo dado em sala de aula, nesse e em outros } \\
\text { semestres, foi suficiente para o aprendizado do tema. }\end{array}$ & 1 & $11,11 \%$ \\
\hline $\begin{array}{l}\text { Tive dificuldade de acesso a Plataforma Moodle pela minha rede } \\
\text { de Internet. }\end{array}$ & 2 & $22,22 \%$ \\
Não consegui acessar a Plataforma Moodle pelo meu celular. & 2 & $22,22 \%$ \\
Não gostei da proposta de ensino online. & 1 & $11,11 \%$ \\
Já domino o tema abordado. & 0 & $0 \%$ \\
\hline
\end{tabular}

O pós-teste aplicado aos alunos do grupo B (começaram a participar do emódulo, e não terminaram) mostrou que $72 \%$ dos participantes não acessaram a Plataforma porque "não tiveram tempo" e $27 \%$ afirmaram ter dificuldade de acessar a Plataforma pelo celular. As demais opções estão elencadas na tabela 2.

Tabela 2. Pós-teste de satisfação. Grupo B: Participantes que não concluíram o e-módulo (11 alunos)

\begin{tabular}{|l|c|c|}
\hline $\begin{array}{l}\text { Comecei a participar da Disciplina de E-learning em Diagnóstico } \\
\text { Bucal e não fui até o final porque: (marque quantas alternativas } \\
\text { forem adequadas) }\end{array}$ & N & $\%$ \\
\hline Não tive tempo de acessar a Plataforma Moodle. & 8 & $72,72 \%$ \\
\hline
\end{tabular}




\begin{tabular}{|l|c|c|}
\hline O tema abordado não era do meu interesse (Princípios de & 0 & $0 \%$ \\
Interpretação radiográfica de lesões ósseas). & 1 & $9,09 \%$ \\
\hline $\begin{array}{l}\text { A participação no Moodle não trazia acréscimo de nota ou de crédito. } \\
\text { Tive dificuldade de acesso à Plataforma Moodle pela minha rede de } \\
\text { Internet. }\end{array}$ & 0 & $0 \%$ \\
$\begin{array}{l}\text { Não consegui acessar a Plataforma Moodle pelo meu celular. } \\
\text { Achei o conteúdo muito difícil. }\end{array}$ & 3 & $27,27 \%$ \\
\hline Tive dificuldade em acessar os textos, as imagens e as atividades. & 1 & $9,09 \%$ \\
Achei as atividades difíceis de serem realizadas. & 1 & $9,09 \%$ \\
\hline O conteúdo não correspondeu ao que eu esperava. & 1 & $9,09 \%$ \\
\hline
\end{tabular}

Dos 20 participantes que de algum modo não foram até o final da disciplina (Grupo A + Grupo B), 90\% afirmaram que gostariam que houvesse maior oferta de conteúdos via Internet pela universidade. Ao avaliar se eles teriam interesse em participar da disciplina em outra Plataforma que não fosse o Moodle, 35\% relataram "com certeza", 20\% "provavelmente sim". Ao sugerir que outro tema fosse ofertado no e-módulo, 45\% dos alunos afirmaram que provavelmente teriam mais interesse em participar. Quanto à participação no e-módulo, caso a este fosse atribuído nota ou crédito, 35\% afirmaram "com certeza" ter maior interesse em participar, 40\% afirmaram que "provavelmente sim".

No pós-teste de satisfação, os alunos do Grupo C afirmaram que participar da disciplina aumentou o interesse sobre o conteúdo de lesões ósseas. Concordaram que a disciplina os encorajou a estudar e que foi uma experiência proveitosa para graduação. Afirmaram que o conteúdo estava bem ilustrado e que acessaram a Plataforma sem maiores problemas. Posicionaram-se "neutros" quanto à afirmação de que a disciplina consumiu muito tempo, e quanto ao e-módulo ser mais efetivo que aprender em sala de aula. Sobre a RA, um aluno concordou que a ferramenta o ajudou a compreender espacialmente as lesões.

Ambos classificaram como "muito boa" a assistência para solução de dúvidas relacionadas ao conteúdo e ao uso da Plataforma Moodle. 
Ao final do pós-teste de satisfação dos três grupos, havia um espaço em aberto para os alunos expressarem críticas e sugestões quanto a sua experiência com o emódulo.

\section{Discussão}

Contrariamente ao descrito na literatura, tivemos uma baixa adesão dos alunos participantes do e-módulo. Somente dois, dos 25 alunos iniciais, participaram até o final. A que atribuir a baixa participação? Não poderia ser pela plataforma escolhida, já que $96 \%$ dos participantes relataram já ter experiência com o Moodle, e 64\% classificaram a Plataforma como "boa", na primeira avaliação de expectativa. Outra variável seria o perfil dos estudantes. Os alunos responderam que apreciavam trabalhar com computadores (60\% dos 25 participantes iniciais) e 19 dos 20 estudantes participantes do pós-teste relataram ter conhecimento moderado em computação. O trabalho de Stein et al. ${ }^{17}$ (2013) relata que é um mito afirmar que os alunos de Odontologia são especialistas em tecnologia, podendo usar de seus recursos com propriedade e completo domínio. O contraste do perfil dos voluntários com a baixa participação reforça a ideia de que embora esses estudantes sejam "nativos digitais", não empregam a tecnologia de forma estratégica para otimizar a aprendizagem. A facilidade de acesso às ferramentas de pesquisas e a velocidade de busca de informações disfarçam problemas preocupantes como a dificuldade de apropriação de conhecimento pelo aluno através dos meios tecnológicos.

No questionário respondido pelos alunos que não participaram do e-módulo, 88,8\% alegaram não ter tempo para acessar a Plataforma. É importante considerar o fato de que foi decidido implementar o e-módulo paralelamente à disciplina de Diagnóstico Bucal, porém sem diminuir a carga horária do ensino presencial. Portanto, os alunos teriam que organizar seu horário para disponibilizar parte do tempo ao emódulo. Porém, os dois alunos que concluíram o e-módulo se posicionaram "neutros" quanto à disciplina consumir muito tempo. Assim, concluímos que a carga horária da implementação do e-módulo não gerou sobrecarga para os estudantes. A justificativa de falta de tempo não procede. No mito número dois do trabalho de Stein et al. ${ }^{17}$ (2013) é relatada a dificuldade de os estudantes fazerem pesquisas ou desenvolverem atividades na Internet que exijam mais tempo e que envolvam maior nível de 
complexidade. Uma justificativa seria por medo de perder tempo com aquela atividade. $\mathrm{O}$ autor afirma que os alunos podem começar uma busca a partir da menor provocação, mas que também desistem facilmente quando envolvido maior grau de dificuldade. Encontramos essa realidade em nosso trabalho quando dos 25 voluntários, oito participaram do primeiro fórum de atividades, e somente dois chegam ao final do e-módulo.

Podemos sugerir, na avaliação dos dados obtidos pelos questionários, a presença do fenômeno da "desejabilidade social". Este pode ser entendido como uma propensão das pessoas a responder aquilo que seria o socialmente mais aceitável e negar sua associação pessoal com opiniões e comportamentos que a sociedade desaprovaria. ${ }^{18}$ Afirmar que não teve tempo para realizar uma atividade é mais aceito socialmente que afirmar que o tema abordado no e-módulo não era do interesse pessoal, já que todo conteúdo oferecido no ambiente universitário deveria de ser de interesse de todos. Outro exemplo ocorre quando, dos 20 alunos que não participaram da disciplina ou que desistiram ao longo do e-módulo, 90\% afirmam querer que mais conteúdos fossem disponibilizados via Internet pela universidade. Considerar a ocorrência desse evento é fundamental para avaliar a presença de respostas tendenciosas em dados qualitativos.

Assim, restam as questões pedagógicas relativas à escolha do tema, do software, isto é, sobre os itens apontados no pós-teste de expectativa.

O tema abordado no e-módulo foi escolhido com o objetivo de complementar o conteúdo ministrado em sala de aula, bem como o conteúdo já ensinado em semestres anteriores. Portanto, o conteúdo do e-módulo era complementar, e não estava diretamente relacionado ao conteúdo ministrado semanalmente na disciplina de Diagnóstico Bucal ao longo do semestre. Dos nove participantes que não acessaram o e-módulo, nenhum relatou já ter domínio do tema abordado. Com os baixos índices de participação, observamos que o tema, apesar de não ser dominado, não atraiu a atenção dos participantes. Mesmo o tema "Princípios de interpretação radiográfica" sendo de total relevância prática, podemos sugerir que os alunos tendem a concentrar seus esforços em conteúdos que serão cobrados posteriormente em avaliações. Assim, deixam passar despercebidos conteúdos de extrema importância fornecidos pela Universidade através de outras metodologias de ensino. Esse fato 
remete a dados apresentados no trabalho de Nkenke et al. ${ }^{16}$ (2012), quando afirma que os alunos têm a tendência a não compreenderem a relevância prática dos temas trabalhados nos ensinos online. Nessa pesquisa, o autor também mostra através dos baixos índices encontrados no questionário que os alunos não se preparam antecipadamente para as aulas através de leituras básicas regulares. Isso sugere um aprendizado passivo, centrado na figura do professor e em memorizações de conteúdo antes das provas.

Galvão e Magalhães ${ }^{19}$ (2008), em um estudo no curso de medicina na Universidade de Brasília, ofertaram exercícios diretamente relacionados ao conteúdo abordado em sala de aula e utilizaram outro ambiente virtual que não o Moodle. A participação era facultativa. Tiveram $84 \%$ de participação nessa ferramenta. Assim, constatamos a importância de os conteúdos estarem interligados presencialmente e na ferramenta de ensino online. É possível que o fato de os conteúdos não estarem interligados entre a aula presencial e o e-módulo tenha sido um dos fatores determinantes na baixa adesão encontrada em nosso trabalho. Entretanto, dos exercícios disponibilizados no estudo de Galvão e Magalhães ${ }^{19}$ (2008), 52\% foram resolvidos nas 24 horas que antecediam as provas. Esse fato sugere um perfil de alunos passivos, que concentram seus esforços para o aprendizado nas vésperas das provas, comprometendo a aquisição de conhecimento efetivo e o objetivo da ferramenta.

Em nosso estudo, a participação era facultativa, não havia acréscimo de nota, nem de crédito ao aluno. Assim, dos nove participantes que não acessaram o Moodle, dois deles afirmaram não ter participado do e-módulo por não ter acréscimo de nota ou crédito. Entre os 11 participantes que começaram e desistiram ao longo do emódulo, um participante também expressou essa opinião.

Segundo Peixoto et al. ${ }^{20}$ (2005), apesar de os alunos se adaptarem facilmente às novas tecnologias, eles ainda são resistentes à efetividade delas. Afirmam que a nota ainda é a forma mais atrativa, mas deve servir apenas como pontapé inicial, sendo responsabilidade do professor utilizar outros fatores motivacionais. Christofoletti et al. ${ }^{6}$ (2014) também afirmam que mesmo com a boa aceitação das metodologias ativas de aprendizagem, os alunos relatam dificuldades para se adaptarem a novos métodos de ensino. 
Ao avaliar a construção e desenvolvimento do e-módulo dentro do Moodle, na área de Radiologia Odontológica, os professores observaram que se trata de uma ferramenta que limitou a abordagem do tema escolhido, sendo trabalhosa a elaboração principalmente das atividades, e tornou estas também mais difíceis de serem resolvidas pelos alunos. Esse fato parece se contrapor ao objetivo inicial, que era fornecer uma ferramenta que facilitasse e dinamizasse o aprendizado do aluno. Oposto as limitações encontradas neste trabalho, um estudo com o uso do Moodle na disciplina de Informática em Enfermagem considerou o Moodle uma ferramenta que permitiu ao docente desenvolver as aulas, atividades, discussões e avaliações de forma simples. Além disso, proporcionou uma forma de comunicação eficaz, fora da sala de aula. ${ }^{2}$

A tutora e a desenvolvedora das atividades foram as responsáveis pela comunicação com os estudantes, usando o e-mail como ferramenta virtual de incentivo. Essa tentativa não foi bem vista pelos alunos, como podemos observar no discurso dos alunos:

"A parte de receber as respostas e correções dos trabalhos

é cansativa e desinteressante principalmente pela quantidade de e-mails". (Aluno 1)

"Também gostaria de sugerir, desabilitar (não sei se essa ferramenta é disponível no Moodle) o recebimento de todos os e-mails. Toda vez que alguém postava algo, todos recebiam e-mail notificando. Isso enche a caixa de entrada e esconde e-mails importantes que ficam entremeados." (Aluno 2)

Peixoto et al. ${ }^{20}$ (2005), em seu estudo com professores e alunos de pósgraduação, relatam que $100 \%$ dos participantes consideram o modelo híbrido de ensino como ideal, porém a maioria relatou utilizar uma metodologia de ensino mais tradicional. Relataram a dificuldade pela própria faculdade, muito presa às aulas expositivas, e falta de aptidão com recursos tecnológicos. Em contraste com a ideia apresentada por Peixoto et al..$^{20}$ (2005), no presente trabalho foi proposta a mudança, por meio do e-módulo, do ensino tradicional centrado na aquisição passiva de conhecimento. Os participantes tinham fácil acesso ao computador e à Internet, 
tinham conhecimento para o uso das ferramentas, mas ainda assim, não aderiram ao ideal proposto.

Percebe-se que apenas a tecnologia não é capaz de transformar o paradigma da educação passiva para a ativa, pois não apresenta, por si só, atrativos suficientes para concretizar mudanças. Apesar da baixa adesão dos alunos, foi possível constatar uma realidade presente em outros trabalhos: a dificuldade dos alunos em se adaptarem a novos métodos de ensino. Embora a presente geração tenha acesso e facilidade em utilizar computadores e para comunicação e rápidas pesquisas, ainda necessitam de recompensas, como o acréscimo de nota, para fazer desses dispositivos, ferramentas de educação.

Permanece a necessidade da capacitação dos docentes para esse novo cenário, cabendo a este compreender os desafios embutidos na construção do conhecimento mediado por computadores, a escolha adequada da ferramenta para cada situação e, principalmente, como motivar os estudantes a serem sujeitos ativos do processo educacional.

\section{Conclusão}

No presente trabalho, observou-se que o e-módulo desenvolvido na Plataforma Moodle foi pouco acessado pelos alunos de graduação em Odontologia, apesar de os participantes se mostrarem positivos à introdução de metodologias baseadas em ambientes virtuais de ensino, conforme constatado em questionário de satisfação. Já o desempenho apenas pôde ser avaliado entre os dois participantes que concluíram o e-módulo, mostrando-se similar ao desempenho geral dos alunos que acompanharam as aulas presenciais.

Conclui-se que vários fatores podem estar relacionados à participação dos alunos no ambiente virtual de ensino, incluindo o ganho de recompensas, como nota ou créditos, facilidade no uso de ferramentas online e a forma pedagógica como o e-módulo foi desenvolvido, e que apenas a tecnologia não é suficiente para motivar os estudantes. Portanto, o papel do professor é fundamental no processo de ensino 
ativo centrado no aluno, abrangendo tanto a função motivacional quanto função mediadora entre o mundo virtual e o aprendizado.

\section{Abstract}

E-learning can be defined as any type of educational situation in which the content is available electronically via Internet when and where people need it. Using the possibilities that virtual environment provides for education, was developed an emodule in the Moodle Platform. The aim of this study was to verify the access, performance and acceptance of undergraduate dentistry students to use the e-module in the online activities of Oral Diagnosis Discipline at the University of Brasilia. Evaluations of content (pre and post-test), pre-test of expectation and post-test of satisfaction were designed to evaluate the content and acceptance of e-module among participants. Of the 25 initial participants, 2 completed the e-module, 11 started and did not complete, 9 did not access the platform and three did not accept to answer the post-test of satisfaction. Pre and post-test of content showed no significant data. The post-test of satisfaction showed that the students who have not accessed the emodule, or accessed and did not complete, $80 \%$ said they "did not have time to access the Platform" and $15 \%$ said they did not participate, or did not complete the e-module "because it would not improve GPA or course credit number". ". In conclusion, although students were positive regarding the use of new methodologies, the participation was very low. The performance was similar to presential classes. Several factors influence the attitude of the students in the e-module, including rewards gain and the pedagogical form of the contents. Thus, it is up to the teacher the motivational and mediating role between learning and the virtual world.

\section{Descriptors}

Dentistry; Radiology; Education, Distance; Information Technology.

\section{Referências}

1. Barros WM, Altermann CDC, Alves N, Borges S, Menezes JR, Carpes PBM. Uso do Moodle como ferramenta de apoio ao ensino de fisiologia humana em cursos da área de saúde. Rev Biomotriz 2013;7(2):112-29 
2. Salvador ME, Sakumoto M, Marin HF. Uso do Moodle na Disciplina de Informática em Enfermagem. J Health Inform2013;5(4):121-6. [Acesso em 17 jan. 2015]. Disponível em: www.jhi-sbis.saude.ws

3. Handal B, Groenlund C, Gerzina T. Dentistry student's perceptions of learning management systems. Eur J Educ 2010;14(1):50-4.

4. Zhang D, Nunamaker JF. Powering e-learning in the new millennium: an overview of e-learning and enabling technology. InformSyst Front 2003;5(2):207-18.

5. BRASIL. MINISTÉRIO DA EDUCAÇÃO (MEC). Portaria no 4.059 de 10 de dezembro de 2004. DOU de 13/12/2004, seção 1, p. 34.[Acesso em 20 fev. 2015].

6. Christofoletti G, Fernandes JM, Martins AS, Junior SAO, Carregaro RL, Toledo AM. Grau de satisfação discente frente à utilização de métodos ativos de aprendizagem em uma disciplina de Ética em saúde. REVEDUC 2014;8(2):188-97 doi: $\underline{10.14244 / 19827199823}$

7. Rocha, JSY. Uso de tecnologias da informação e comunicação na educação em saúde. Problematização e desenvolvimento. Medicina (Ribeirão Preto). 2015;48(3):214-23.[Acesso em 21 jan. 2015]. Disponível em:<http://www.revistas.usp.br/rmrp/article/view/104297>

8. Silva RHA, Perim GL, Abdalla IG, Costa NMSC, Lampert JB, Stella RCR. Abordagens pedagógicas e tendências de mudanças nas escolas médicas. RevBrasEduc Med 2009;33(Suppl 1):53-62.

9. Franco CP. O uso de um ambiente virtual de aprendizagem no ensino de inglês: além dos limites da sala de aula presencial [dissertação]. Programalnterdisciplinar de Pós-Graduação em Linguística Aplicada, Faculdade de Letras.Universidade Federal do Rio de Janeiro, 2009.

10. Barbosa MFSO, Rezende F. A prática dos tutores em um programa de formação pedagógica a distância: avanços e desafios. Interface - Comunic Saúde Educ 2006;10(20):473-86, 2006.

11. Araújo IMZC, Silva JRS, D’Assunção FLC, Melo ABP. Avaliação da percepção dos alunos da disciplina de endodontia sobre o uso do Ambiente Virtual de Aprendizagem (Moodle). Uso do questionário de auto-avaliação COLLES.Rev ABENO 2012;12(2):163-9. 
12. Ribeiro PS. Manual de utilização do moodle 1.9. Perfil Professor Versão 1.0. Universidade Federal do Pampa, 2010.[Acesso em 7 dez. 2014]. Disponível em: https://moodle.unipampa.edu.br/file.php/1/Manual de utilizacao do Moodle 1.9 - Manual do Professor - Versao 1.pdf

13. Santos GNM, Rosa EL, Leite AF, Figueiredo PTS, Melo NS. Augmented reality as a new perspective in dentistry: development of a complementary tool. Rev ABENO 16(3):19-27, 2016.

14. White S, Pharoah M. Radiologia Oral. Fundamentos e Interpretação. $7^{\underline{a}}$ ed. Rio de Janeiro: Elsevier, 2015, 696p.

15. Meckfessel S, Stuhmer C, Bormann KH, Kupka T, Behrends M, Matthies H, et al. Introduction of e-learning in dental radiology reveals significantly improved results in final examination. J CranioMaxillofac Surg 2011;39:40-8.

16. Nkenke E, Vairaktaris E, Bauersachs A, Eitner S, Budach A, Knipfer C, et al. Spaced education activates students in a theoretical radiological science course: a pilot study. BMC Med Educ 2012;12:32.doi:10.1186/1472-6920-12-32.

17. Stein CD, Eisenberg ES, O'Donnel JA, Spallek H. What Dental Educators Need to Understand About Emerging Technologies to Incorporate Them Effectively into the Educational Process. Journal of Dental Education 2014;78(4):521-9.

18. Junior RCR, Moura MLS, Hutz CS. Adaptação brasileira da Escala de Desejabilidade Social de Marlowe-Crowne. Aval Psicol 2004;3(2):83-92.

19. Galvão MF, Magalhães AV. Sistema de exercício online para apoio a aprendizagem de Medicina Legal na Universidade de Brasília. RevBras Educ Med 2009;33(1):84-91.

20. Peixoto RTRC, Gonçalves PVAJ, Alvim HH, Amorim HCS, Araújo AVA. O emprego das tecnologias de informação e comunicação no ensino superior: um relato de experiência sobre a oficina "Modelo Híbrido de Ensino". Rev Docência Ens Sup 2015;5(1):183-204.

Correspondência: Brendda Juliana Carvalho Feitosa

SGAS 606 Bloco A Instituto Vicenta Maria-70200-660 - Asa Sul - Brasília - DF

E-mail: brendda_ju@hotmail.com 


\title{
APÊNDICE 4 - TEACHING AND LEARNING ORAL RADIOLOGY VIA THE SOCIAL MEDIUM WHATSAPP
}

\section{Teaching and learning oral radiology via the social medium WhatsApp}

\section{Ensinando e aprendendo radiologia oral via mídia social WhatsApp}

New Technologies to support teaching of undergraduate dentistry Novas tecnologias de apoio ao ensino de graduação em Odontologia

Glaucia Nize M Santos, Ms*, André F Leite, PhD*, Paulo T de S Figueiredo, $\mathrm{PhD}^{*}$ and Nilce $\mathrm{S}$ de Melo, $\mathrm{PhD}^{*}$.

*Department of Dentistry, Health Sciences Faculty, University of Brasília, Brasília, Brazil;

\begin{abstract}
Social media can be defined as Internet-based applications that allow the widespread creation and exchange of user-generated content. The ease with which social media can be accessed through numerous mobile devices encourages medical educators to use social media to share content with students outside the classroom. The aim of this study was to introduce WhatsApp as a teaching tool in an Oral Radiology course. The secondary objective was to assess students' attitudes towards the use of this innovative tool in teaching of dentistry. In the first semester of 2016, 30 second-year undergraduate Dentistry students at the University of Brasília were provided with weekly quizzes via a WhatsApp discussion group. The quizzes consisted of a tomographic or radiographic image from a real clinical case and a multiple-choice question. At the end of the semester students' attitudes were assessed using a satisfaction questionnaire. The results showed that students had a positive attitude towards the use of WhatsApp and considered it had helped them to learn about Oral Radiology. In conclusion, this technology can improve the way material is taught, since
\end{abstract}


educators are prepared to develop better learning environments and students are concerned about the potential use of the social media in education.

KEYWORDS: Social Media; Education; Communication; Oral Radiology; Dentistry.

\section{INTRODUCTION}

Social media are defined as Internet-based applications in which usergenerated content is created and exchanged by large numbers of people. The ease with which students can assess social media through mobile devices, such as smartphones, tablets, laptops and e-readers, and the increasing amount of time they spend doing so encourages medical educators to use these media to share educational content outside the classroom. ${ }^{1}$

The functions of smartphones - Internet browsing, email access, high-quality camera and a wide range of applications, popularly known as "apps" - are innovative tools that can be used for mobile learning (m-learning). Conventional blogging sites and micro-blogging tools such as Twitter, social networks as Facebook, video contentsharing sites as YouTube, cloud storage sites like Google Docs, and Internet-based communication software as Skype and WhatsApp show great potential to improve medical education, as they allow health care students to access resources conveniently and easily, and communicate quick and effectively. ${ }^{2,3,4}$

Because learning via social media forces students to interact and collaborate to solve problems it deepens the learning experience. ${ }^{5,6}$ Active learning is an instructional approach in which students are required to participate in the learning process by interacting during the course of meaningful activities that lead them to think about their attitudes. Active learning is a valuable tool that has potential to enhance learning via social media applications.

The advantages of introducing social media into the learning process include the opportunities for collaboration amongst users, creation of personal content via different media and sharing of individual work, as well as construction of new approaches to research. ${ }^{7}$ For educational purposes, social media combines a strong 
social component with user-generated content in the forms of text, video and photographs as well as comments, tags, and ratings. ${ }^{8}$ The main value of social networking applications is as an egalitarian, efficient means of spreading information relevant to pedagogical goals; they also allow educator to create a sense of social learning and engagement within a community. ${ }^{9}$

Instant Messaging (IM) is a term used to describe the way users communicate instantly via their mobile devices, mainly smartphones, and it has become one of the most popular methods of communication amongst health professions. ${ }^{10}$ Nowadays, the most popular messaging application is the WhatsApp Messenger, which has more than one billion users worldwide. WhatsApp was designed to replace short message service (SMS) with an Internet-based platform thus allowing users to avoid the international fees that mobile providers charge. ${ }^{11}$

Despite the increasing use of these creative applications for educational purpose in the university environment, dental courses still rely on traditional forms of teaching. The primary aim of this study was to introduce the social medium WhatsApp as a teaching tool in an Oral Radiology course. The secondary aim was to evaluate students' attitudes towards the use of this innovative tool as part of their dental studies.

\section{MATERIALS AND METHODS}

This descriptive study was approved by the ethics committee of University of Brasilia under the number CAAE 42277115.3.0000.0030. The social medium WhatsApp was used to create a discussion group involving 30 second-year undergraduate Dentistry students of University of Brasília who were following an coursing the Oral Diagnosis course, covering oral and maxillofacial anatomy, interpretation of radiographic bone lesions and dental caries, and identification of tooth anomalies, cysts and neoplasms. The participation in the discussion group started after the written informed consent form agreement, and was not a requirement of the course. Participants consented to make their cell phone numbers available to the researcher, who undertook not share them with anyone outside the research team, in order to ensure participants' privacy.

Three titular professors and two tutors were also added to this Internet-based discussion group via smartphone. During the first semester of 2016, the content of the 
Oral Radiology course was delivered face-to-face by the titular professors. During the same period, the tutors used WhatsApp to publish a weekly quiz, with one question per quiz. The quizzes were published four to six hours after face-to-face classes and covered the same material. Each quiz consisted of a tomographic or radiographic image from a real clinical case and a multiple-choice question. Students could also use the platform to ask questions about issues discussed in class.

The quizzes were created in the form of Power Point slides, saved in .jpeg format and shared with the WhatsApp discussion group. After students had posted their answers, the tutors started a discussion based on the images shown in the quiz as a way of encouraging students to review the material covered in class. Every message sent was counted, including mistakes and successes achieved by the students in each activity as well as their contributions to discussions.

At the end of the semester, a satisfaction questionnaire consisting of 12 questions in Likert scale format and an open point-of-view question, was applied to the students, to assess participants' attitudes to use the app for Oral Radiology education and get a feedback about the presentation and content of the quizzes. The satisfaction questionnaire was free-based in the TRIL questionnaire (Trierer Inventar zur Lehrevaluation - educational evaluation questionnaire of Trier University) by Gläßer et al. (2002, apud Nkenke et al. 2012). ${ }^{12}$

\section{RESULTS}

All students on the course opted to join the WhatsApp Oral Radiology discussion group and all had mobile phones connected to the Internet. Weekly quizzes were made available over a fourteen-week period. Twenty-eight (17 women; 11 men) of the 30 participating students added comments to discussions of at least two quizzes. The percentage of students participating in a quiz, which ranged from $66.67 \%$ for the first quiz to $23.33 \%$ for the penultimate quiz, is shown in Graphic 1 .

Students made a total of 372 posts, consisting of right and wrong answers to the quizzes, comments on the content discussed, questions about other oral radiology issues and marketing of oral radiology lectures. There were more correct answers to quiz questions (37, $9.43 \%$ of posts) than incorrect answers (17, 4.34\% of posts) and quizzes related to oral and maxillofacial anatomy questions had more correct answers. 
There were far more posts discussing the topics than there were correct or incorrect answers to quiz questions.

At the end of the fourteen-week period, a satisfaction questionnaire was applied to the students. The questionnaire covered students' attitude towards receiving and answering quizzes through the Instant Messaging discussion group. Responses were given using a Likert scale ranging from 1 (I totally disagree) to 5 (I totally agree).

The questions were free-based in the TRIL questionnaire (Trierer Inventar zur Lehrevaluation - educational evaluation questionnaire of Trier University) by Gläßer et al. (2002, apud Nkenke et al. 2012) ${ }^{12}$ which consists in a six topics modular Germanlanguage questionnaire for the evaluation of courses at university, not validated in Portuguese language (Table 1).

The Topic 1 responses showed that students were satisfied with the virtual environment provided in WhatsApp; they agreed it was didactic, clear, objective and in a good frequency. Topic 2 responses revealed that having a teacher available online was very important to the students. Topic 3 responses showed that students agreed that the quizzes matched the face-to-face content and found group discussions useful. Topic 4 consisted of two questions about the practical relevance of the course and responses indicated that students appreciated receiving the selected images via WhatsApp and felt that the images had helped them to learn new information. In responses to Topic 5 the majority of students rated WhatsApp as an effective educational tool, although the variance in responses was very high. Responses to Topic 6 showed that students did not agree that social media helped them to remember information and that they had found the questions really hard.

At the end of the questionnaire students were encouraged to provide additional comments about the use of WhatsApp, and 23 (92\%) did so. These responses are presented in the discussion below.

\section{DISCUSSION}

The main findings of this study are that students' evaluated the WhatsApp discussion group positively and considered it helpful to their Oral Radiology course. It is important to highlight that the participation level was lower than expected by 
educators, even though all students had easy access to mobile phones and the Internet.

In 1987 Chickering and Gamson ${ }^{5}$ proposed seven principles of good teaching and learning in colleges, including high expectations, good communication between students and faculty, reciprocity and cooperation among students, active learning and prompt feedback. Also time on task and respect to talents and ways of learning diversity should be emphasized. WhatsApp and other instant messaging applications meet these criteria for best practice in education and have a beneficial effect on learning. ${ }^{13,14}$ We found that use of social media increased the amount of contact between professors and students and this was cited by some participants as the main benefit:

“(...) Easier communication makes it easier to resolve queries.", "The main point is communication. In the app, information has no interruption which helps us to enhance our knowledge through ordinary chats.", "An easy and quick access tool. It shows great interactivity."

Cooperation between students was also observed as they created and shared content amongst themselves in the WhatsApp group. It gave value to the students' time spent in researching and studying:

"Students could ask questions and share contents such as scientific articles, slides, images, etc", “(..) the debate encouraged us to think more and better assess dental radiographies."

In addition, tutors responded quickly to students in this dynamic learning environment. ${ }^{15}$ Prompt feedback made students feel more comfortable and secure about their posts, thus enhancing the learning experience:

"It induced us to study more.", "Very accessible information and interactive debate", "Questions could be resolved as soon as they arose. It helped to remember the content."

Responses to the satisfaction questionnaire confirmed that the WhatsApp discussion group complied with the principles of good teaching and learning cited 
above. Students mentioned that they liked working in group, getting feedback quickly, being encouraged to study independently and, in particular, having a teacher available online:

"The content and deadline for learning were excellent, including the debates.", "It was a quick way of getting help with the material covered in face-to-face classes.", "It was good for evaluating the other students' level (...) and for seeing if the group's opinion was the same as mine.", "The WhatsApp discussion group gave us a way of going through information about radiology during the week.", "The main positive point was the opportunity to review the content in an easy, objective and quick way (...)", "The activity was good way of reminding us about diagnostic material and encouraging us to go through it again.", "It was good to test what we had learned and it encouraged us to search for the right answers.", "(..) Having an online teacher is VERY IMPORTANT.”, "It was great to have an online teacher to resolve queries (...)"

The availability of a teacher was a particular advantage to students who were too scared or shy to ask questions in class. It is important to highlight that the majority of the students were positive about working in a group because it allowed them to compare their performance with that of their peers. This can be explained by the Hawthorne effect, a student's productivity is not determined by his or her physical capacity but by social interaction and group expectations prevailing in the university environment. ${ }^{16}$ Nevertheless, one student disapproved of the group learning aspect of the use of WhatsApp:

"Working in a group was not good."

Gonzalez and Gadbury-Amyot (2016) $)^{17}$ evaluated dental students' use and perceptions of the social medium Twitter for teaching and learning as part of an Oral Radiology course. Twitter sessions were perceived as helpful and they improved instructor accessibility. In our study, most of the students rated WhatsApp an efficient method of learning, confirming that they are positive about use of social media in education: 
"I think it is an instructive and accessible method of learning.", "It was great to see more clinical cases relating to the material we were learning."

November ${ }^{18}$, an international leader in education technology, stated that the world had recognized the power of social media to provide worldwide information and communication. Educators have a fundamental role in understanding the potential of these tools and offering genuine experiences to students and are capable to widespread their own personal learning networks. Teachers should connect students to real-world problems and provide examples of how to use the most powerful social media tools to expand the boundaries of learning.

Dental faculty members have indicated that they are uncertain about how to use social media in teaching and learning. This study investigated the first use of a WhatsApp discussion group, a learning tool not previously used in Oral Radiology education. Participants complained about multiple-choice questions because it seemed that the responses were merely copies, which demonstrates educators' lack of experience in creating a pedagogical environment in social media. Results suggest that the best use of WhatsApp may be as an online question and answer tool rather than for quizzes:

"Because the quizzes were built as multiple-choice questions, the repetition of the responses seemed that students were copying from one another.", "Many times it seemed that we were simply copying the answers."

To cope with the challenges that rise of technology poses, universities must aim to provide professional development resources, such as programs to enhance faculty members' pedagogical skills. ${ }^{19}$ Our study demonstrates that to meet the demands of the "digital generation" educators must increase their engagement with students' preferred communication tools, focusing on achieving a deeper understanding of how they can be used to improve students' learning and foster their creativity and selfdirection. It has been recognized that the most difficult challenge facing dental institutions is the development of new approaches to teaching and learning and the integration of new technologies into classrooms and clinics. ${ }^{19}$ 
Many students fail to see the educational value tools they use routinely for other purposes. Dental students associate social networking services with private discussions and not with dental school interactions. ${ }^{20}$ Students should been given explicit guidance on how to make best use of social media in their education and set specific objectives. ${ }^{18}$

In our study the participation rate for social media quizzes ranged from $66.67 \%$ for the first quiz to $23.33 \%$ for the penultimate quiz. This may be due to several factors. First, the variation may be directly related to the timing of University exams; participants reported that they had not had enough time to keep posting on the social media quizzes whilst revising for exams:

"We could not answer all the quizzes because we have many other disciplines to study.", "We had problems finding the answers to the quizzes due to lack of time to search and study. It is not a methodological fault.", "Often it was hard to find time to search, study and post the answers." "It was very hard to find time to answer to the quizzes posted by the tutor."

Another possibility is that questions got harder over the course of the fourteenweek study period. One student stated that questions did not fit with the content delivered in class, and the lower mean value of the satisfaction questionnaire was related to the quizzes' level of difficulty (Table 1):

"Questions were too hard, incompatible with the face-to-face level content."

Nielsen ${ }^{21}$ argued that although students access numerous multimedia sites such as YouTube, they often avoid aspects of the Internet that they perceive as "difficult" for fear of wasting time. Lack of interest and lack of reward (in the form of better scores, in the discipline) may also explain the decrease in participation over the study period. In other words, the students may not have found the learning environment created by the educators sufficiently attractive to encourage them to keep posting when the questions were challenging.

Social behavior has changes since mobile devices and social media became more accessible. Society has shifted from the "attention age" to the "information age". 
Levy concluded "constantly being accessible makes you inaccessible"22 because extensive use of social media promotes a state of partial attention. Social media allow people to review interpersonal relations and group identity, resulting in an unfiltered, spontaneous, and potentially high-impact style of learning. ${ }^{23}$ Nevertheless use of mobile phones during lectures, tests and examinations has to be regulated in order to protect students' privacy and ensure that no inappropriate communication takes place. ${ }^{15}$

Technology, including mobile devices, has permeated our daily lives and gives us unlimited access to communication and information. All the participants in our study, which was carried out in a public Brazilian University, had smartphones connected to the Internet; however, three participants stated that the posted images were not clear, presumably due to the poor quality of their mobile phones:

"I suppose some images were not clear due to the quality of my smartphone.", "Some images were not good quality.", "Some images were not clear enough."

Willemse and Bozalek ${ }^{24}$ described students' and educators' opinions about the benefits of using mobile devices in an undergraduate nursing program. This study, carried out in Western Cape Province, South Africa, emphasized that only a limited number of students were using smartphones. The researchers recognized that some students were not able to download WhatsApp or Facebook because of the limited capability of their mobile device. Although not all students have smartphones of sufficient quality to allow them to benefit from educational social media applications, the potential benefits of using social media as learning tools are particularly relevant in resource-poor contexts, because they are a free service on mobile phones and computers. ${ }^{11}$

The drawbacks of m-learning are the risk of inappropriate and unprofessional online behaviors, such as patient privacy violations, especially if student anonymity is preserved. ${ }^{25}$ Another disadvantage of WhatsApp is the need to have a connected mobile phone; this means that all participants have access to each other's mobile phone numbers. It also means that students can exchange messages or phone calls 24 hours a day, seven days a week. It is important to highlight that there are plenty of 
other options that may be used as online interactive tool in an educational context and that the effective use of mobile devices in education depends on accessibility, connectivity, infrastructure and technical support.

The limitations to this study are that it was carried out in a single dental school and the sample was small, so the generalizability of the results is limited. A further limitation is that we did not assess whether participating in the WhatsApp discussion group increased students' knowledge of the topics covered.

\section{CONCLUSION}

The social medium WhatsApp was used as a teaching tool for dentistry students following an Oral Radiology course. Teachers need access to better instruction about the demands of the "digital generation" if they are to be able to develop interesting learning environments and know how to use social media tools effectively to expand the boundaries of learning. Students reacted positively to the introduction of this collaborative tool, although participation decreased over time. There are many possible reasons for this: lack of time, lack of reward and the difficult of the tests. More research is needed into ways of using collaborative spaces for participatory learning.

Conflict of interest: None.

All authors confirm that they have nothing to disclose.

Funding: This research was conducted without funding support.

\section{RESUMO}

Mídias sociais podem ser definidas como um grupo de aplicativos baseados em Internet que permitem a criação e troca de conteúdos gerados pelo usuário de forma bastante expandida. A facilidade de as mídias sociais serem acessadas em dispositivos móveis encoraja educadores da área de saúde a compartilhar nessas mídias conteúdos que vão além da sala de aula. O objetivo desse estudo foi introduzir a mídia social WhatsApp como uma ferramenta de ensino no curso de Radiologia Oral. Como segundo objetivo, as atitudes dos estudantes ao utilizar essa nova ferramenta durante a graduação em Odontologia foram avaliadas. No primeiro semestre de 2016, quizzes semanais foram disponibilizados em um grupo de 
discussão no WhatsApp, criado com 30 alunos do segundo ano de Odontologia da Universidade de Brasília. Os quizzes eram compostos por uma imagem radiográfica ou tomográfica de um caso clínico real e uma questão de múltipla escolha. Ao final do semestre, avaliou-se o comportamento dos estudantes por um questionário de satisfação. $O$ estudo mostrou que os alunos têm atitude positiva em relação ao uso do WhatsApp e o consideraram útil para auxiliar o aprendizado de Radiologia Oral. Em conclusão, essa tecnologia é capaz de aprimorar a forma como os conteúdos são ensinados, desde que os educadores estejam preparados para desenvolver melhores ambientes de aprendizado e os estudantes estejam conscientes sobre o potencial uso das mídias sociais para educação.

\section{REFERENCES}

1. Kaplan A, Haenlein M. Users of the world, unite! The challenges and opportunities of social media. Bus Horizons 2010;53:59-68.

2. Gupta B, Koo Y. Applications of mobile learning in higher education: An empirical study. International Journal of Information and Communication Technology Education. 2010;6(3):75-85.

3. Mosa A, Yoo I, Sheets L. A systematic review of healthcare applications for smartphones. BMC Medical Informatics and Decision Making 2012;12:67.

4. Johnson L, Levine A, Smith R, Stone S. The 2010 Horizon Report. Austin, TX: The New Media Consortium; 2010.

5. Chickering A, Gamson Z. Seven principles for good practice in undergraduate education. American Association for Higher Education. 1987.

6. Michael J. Where's the evidence that active learning works? Advances in Physiology Education 2006;30(4):159-67.

7. Crook C, Fisher T, Graber R, Harrison C, Lewin C, Cummings J, et al. Implementing Web 2.0 in secondary schools: impacts, barriers, and issues. United Kingdom: Becta; 2008. 139 p. 
8. Cormode G, Krishnamurthy B. Key differences between Web 1.0 and Web 2.0. First Monday 2008;13(6):1-17.

9. Regenberg A. Tweeting science and ethics: Social media as a tool for constructive public engagement The American Journal of Bioethics 2010;10(5):30-1.

10. Khatoon B, Hill K, Walmsley A. Instant Messaging in Dental Education. Journal of Dental Education. 2015;79(12):1471-8.

11. Yeboah J, Ewur G. The impact of WhatsApp messenger usage on students performance in Tertiary Institutions in Ghana. Journal of Education and Practice 2014;5(6):157-64.

12. Nkenke E, Vairaktaris E, Bauersachs A, Eitner S, Budach A, Knipfer C, et al. Spaced education activates students in a theoretical radiological science course: a pilot study. BMC Medical Education 2012;12(32). http://www.biomedcentral.com/14726920/12/32.

13. Makoe M. Exploring the use of MXit: A cell phone social network to facilitate learning in distance education Open Learning 2012;25(3):251-7.

14. Nicholson S. Socialization in the "Virtual Hallway": Instant messaging in the asynchronous web-based distance education classroom The Internet and Higher Education 2002;5(4):363-72.

15. Dewah $\mathrm{P}$, Mutula S. Mobile phone access and use among students at the National University of Technology (NUST) Bulawayo, Zimbabwe: Implications for academic integrity Innovation. Journal of Appropriate Librarianship and Information Work in Southern Africa: Information Ethics 2013;46:150-65.

16. McCambridge J, Witton J, Elbourne DR. Systematic review of the Hawthorne effect: New concepts are needed to study research participation effects. Journal of Clinical Epidemiology 2014;67(3):267-77.

17. Gonzalez S, Gadbury-Amyot C. Using Twitter for Teaching and Learning in an Oral and Maxillofacial Radiology Course. Journal of Dental Education 2016;80(2):14955.

18. November A, Mull B. How Twitter can be used as a powerful educational tool Creative Commons: NovemberLearning.com; 2012 [cited 2016 July, 15]. 
19. Valachovic RW. Commission on change and innovation in dental education. ADEA Charting Progress. 2006.

20. Stein CD, Eisenberg ES, O'Donnell JA, Spallek $\mathrm{H}$. What dental educators need to understand about emerging technologies to incorporate them effectively into the educational process. Journal of Dental Education. 2013;78(4):520-9.

21. Nielsen J. College students on the web. [Internet\}. 2010 [cited 2016 Jun 28]. Available from: www.nngroup.com/articles/college-students-on-the-web/

22. Levy S. (Some) attention must be paid! Carrying a Black-Berry is admitting that your commitment to your current activity is only partial. Newsweek. 2006 March 27:16.

23. Fuchs C, Hofkirchner W, Schafranek M, Raffl C, Sandoval M, Bichler R. Theoretical foundations of the web: cognition, communication, and cooperationtowards an understanding of web 1.0, 2.0, 3.0. Future Internet 2010;2(1):41-59.

24. Willemse JJ, Bozalek V. Exploration of the affordances of mobile devices in integrating theory and clinical practice in an undergraduate nursing programme. Curationis 2015;38(2):Art. \#1510, 10 pages.

25. Chretien K, Greyson S, Chretien J, Kind T. Online posting of unprofessional content by medical students. Journal of the American Medical Association. 2009;302(12):1309-15.

Corresponding author

Glaucia Nize Martins Santos

University Hospital of Brasília. SGAN 605/606 Avenida L2 Norte Brasília - Distrito

Federal, DF, Brazil

Post code: $70840-901$

e-mail: nize.gal@gmail.com

tel: + $556199113-8119$ fax: + $55613326-3265$ 
Graphic 1 - Response rates for all quizzes uploaded during the semester

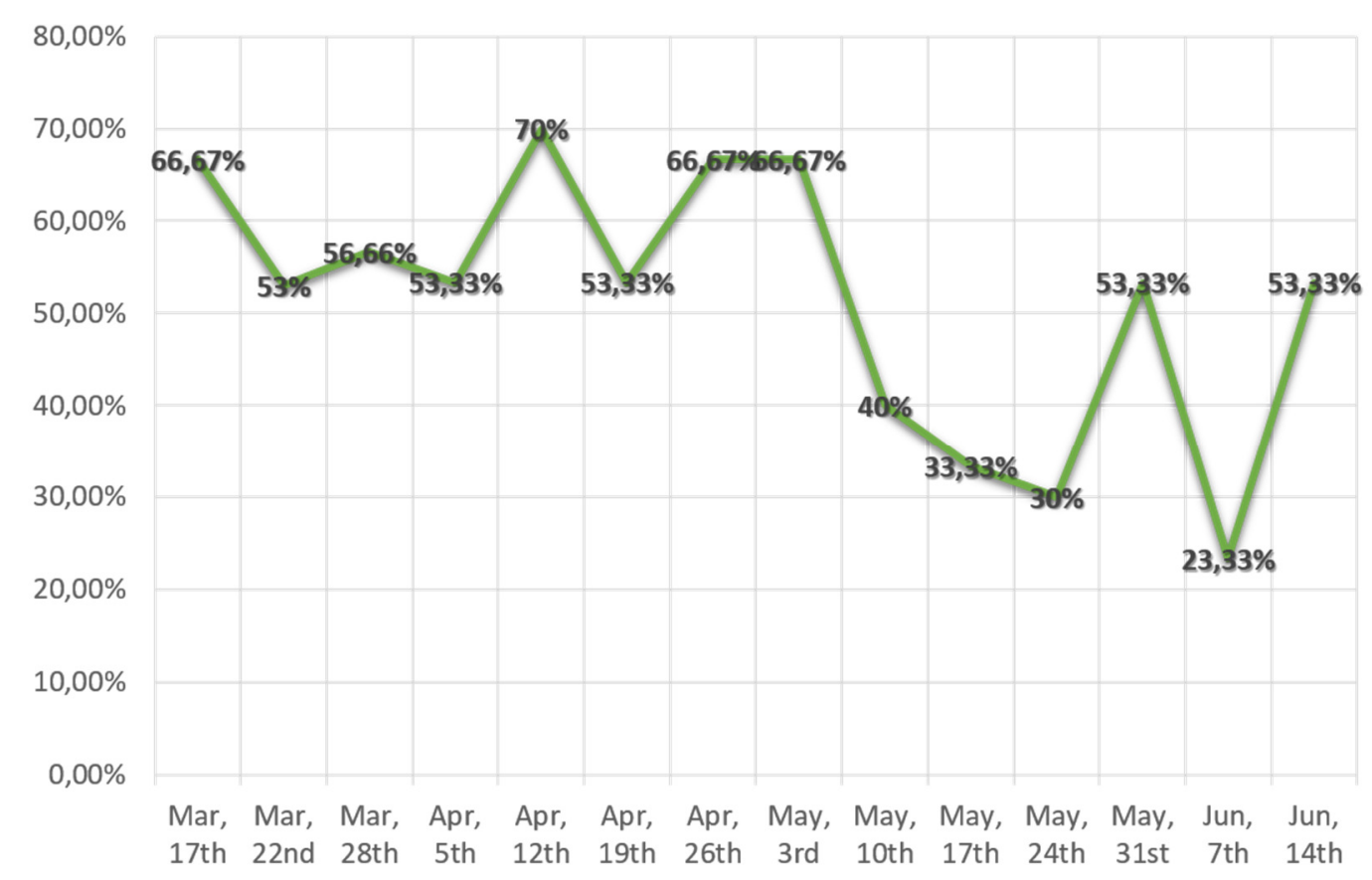


Table 1. Responses to the questions adapted from TRIL (Trierer Inventar zur Lehrevaluation Educational evaluation questionnaire of Trier University)

Instant Messaging group

n Mean SD

Topic 1 Structure and Didactics

Were the questions clear and objective?

$25 \quad 4.08 \quad 0.57$

Was the presentation of material (elements' organization and size, colors, and font size) conducive to learning?

$25 \quad 4.44 \quad 0.50$

Did the sequencing of the questions make learning easier?

25

Was the frequency of activities (weekly) appropriate?

25

$4.08 \quad 0.75$

4.24

0.87

Topic 2 Motivational skills of the lecturer

Was having an online teacher is important to you?

25

$4.68 \quad 0.85$

Topic 3 The extent to which the lecturer created a context conducive to learning

Do you think the activities were a good fit with the face-to-face material? Was the content of online debate useful?

Topic 4 Practical relevance of the course

Were the images posted helpful?

Did you learn new information from the content shared via WhatsApp?

Topic 5 Questions on different additional aspects

Do you think that learning via WhatsApp is efficient?

Topic 6 Homework

Did the content of the activities help you to remember information? 
7. ANEXos 


\section{ANEXo 1 - PARECER FAVORÁVEL do COMITÊ DE ÉTICA}

FACULDADE DE CIÊNCIAS DA
SAÚDE DA UNIVERSIDADE DE Plotoforma
BnB BílLIA - CEP/FS-UNB

DADOS DO PROJETO DE PESQUISA

Título da Pesquisa: E-learning em Diagnóstico Bucal.

Pesquisador: Glaucia Nize Martins Santos

Área Temática:

Versão: 2

CAAE: 42277115.3 .0000 .0030

Instituição Proponente: FACULDADE DE SAÚDE - FS

Patrocinador Principal: Financiamento Próprio

\section{DADOS DO PARECER}

Número do Parecer: 1.074 .979

Data da Relatoria: 13/05/2015

Apresentação do Projeto:

Resumo da pesquisa:

"O e-learning pode ser definido como "qualquer tipo de situaçăo educacional em que o conteúdo instrucional é disponibilizado eletronicamente via Internet quando e onde as pessoas precisam". Do ponto de vista pedagógico, o e-learning tem o potencial de modificar o paradigma do aprendizado passivo centrado no professor para um aprendizado ativo centrado no aluno, sendo ele o responsável pela organização do tempo dedicado ao estudo, pela aquisição de conhecimentos e pelo desenvolvimento de sua aprendizagem. Estudos mostram que os alunos são, em sua maioria, positivos quanto ao uso do e-learning. Uma razão comum é que essa ferramenta oferece flexibilidade, disponibilidade e conveniência, que faltam ao ensino presencial. Em relação às faculdades de Odontologia, a vantagem é que os conteúdos podem ser atualizados e formatados facilmente em tempo conveniente aos professores. Porém, uma variedade de fatores, incluindo pedagogia, comunicabilidade, adaptabilidade e qualidade devem ser mais explorados para que esse método educacional se desenvolva melhor. A Realidade Aumentada (RA), em particular, tem aumentado seu papel no treinamento de profissionais de saúde. Trata-se de uma tecnologia que permite que um objeto (imagem) virtual computadorizado seja sobreposto direta ou indiretamente num ambiente real e em tempo real. Essa pesquisa visa avaliar o uso da forma computacional de ensino a distância, e-learning, no tópico de 'Principios de Interpretação

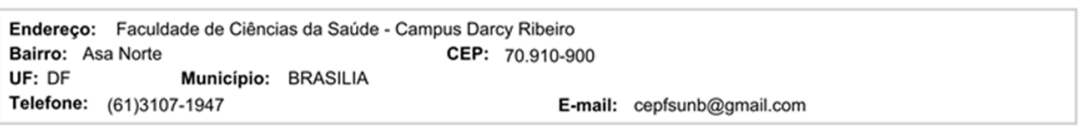




\section{$+7$ \\ UnB}

\section{FACULDADE DE CIÊNCIAS DA \\ SAÚDE DA UNIVERSIDADE DE} BRASÍLIA - CEP/FS-UNB

Continuação do Parecer: 1.074.979

Pendências sanadas.

Protocolo de pesquisa em conformidade com a Resolução CNS 466/2012 e complementares.

Situação do Parecer:

Aprovado

Necessita Apreciação da CONEP:

Não

Considerações Finais a critério do CEP:

Em acordo com a Resolução 466/12 CNS, ítens X.1.- 3.b. e XI.2.d, os pesquisadores responsáveis deverão apresentar relatórios parcial semestral e final do projeto de pesquisa, contados a partir da data de aprovação do protocolo de pesquisa.

BRASILIA, 22 de Maio de 2015

Assinado por:

Marie Togashi

(Coordenador)

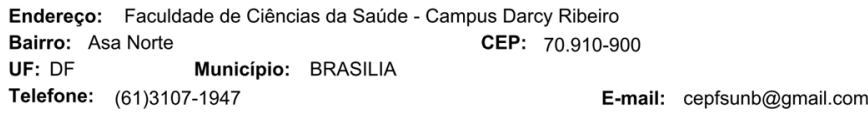




\section{ANEXO 2 - COMPROVANTE DE ACEITE DE ARTIGO}

Decision Letter (0021 Nov 15 JDE.R1)

From: JDEeditor@adea.org

To: nizc.gal@gmail.com, andrclcitc@unb.br

cC:

Subject: Journal of Dental Education - Decision on Manuscript ID 0021 Nov 15 JDE.R1

Body: $02-F e b-2016$

Dear Dr. MARTINS SANTOS:

It is a pleasure to accept your manuscript entitled "Effectiveness of e-learning in oral radiology education: a systematic review." in its current form for publication in the Journal of Dental Education. The comments of the reviewers who reviewed your manuscript are included at the foot of this letter.

If you have not already, you and your co-authors will each need to sign the JDE Publication Agreement Form, the JDE Affirmation of Authorship Form and the JDE Conflict of Interest Form. Please fill out the forms electronically and email a copy of each to burstyns@adea.org

Thank you for your fine contribution. On behalf of the Editors of the Journal of Dental Education, we look forward to your continued contributions to the Journal.

Sincerely,

Nadeem Karimbux, D.M.D., M.M.Sc.

Editor, Journal of Dental Education

JDEeditor@adea.org

Reviewer(s)' Comments to Author:

Reviewer: 1

Comments to the Author

Excellent article, good job on acomplishing all the changes that were recommended

Reviewer: 2

Comments to the Author

This article could add value to anyone involved with predoctoral education specific to radiology as they explore incorporating various technology tools in their curriculum. The article is well written and clear.

Date Sent: $02-F e b-2016$

File 1: $*$ JDE-Affirmation-of-Authorship-Form.pdf

File 2: $*$ JDE-Publication-Agreement-Form.pdf

File 3: * JDE-Conflict-of-Interest-Form-1.pdf 


\section{ANEXO 3 - COMPROVANTE DE ACEITE DE ARTIGO}

COMUNICAÇÃO ENTRE EDITOR/AUTOR

\begin{tabular}{|c|c|}
\hline \multirow{10}{*}{$\begin{array}{l}\text { Editor } \\
\text { 28-09-2016 09:44 }\end{array}$} & Assunto: [Rev ABENO] Decisão editorial \\
\hline & Prezados Autores \\
\hline & $\begin{array}{l}\text { O artigo "Augmented reality as a new perspective in dentistry: development of a } \\
\text { complementary tool." submetido à Revista da ABENO foi avaliado por dois revisores, cujos } \\
\text { pareceres transcrevo a seguir. }\end{array}$ \\
\hline & $\begin{array}{l}\text { Os autores devem preparar um documento com uma lista completa das alterações efetuadas } \\
\text { ou não (com a respectiva justificativa). Este deve ser transferido no sistema como documento } \\
\text { suplementar. }\end{array}$ \\
\hline & $\begin{array}{l}\text { As alterações realizadas no manuscrito devem ser salientadas com a ferramenta "realce de } \\
\text { texto" do Word. O novo arquivo deverá ser transferido na submissão original e não iniciar } \\
\text { uma nova submissão. }\end{array}$ \\
\hline & O prazo para transferir a nova versão no sistema é de 5 dias. \\
\hline & Estou à disposição para eventuais esclarecimentos. \\
\hline & Atenciosamente \\
\hline & $\begin{array}{l}\text { Vania Fontanella } \\
\text { vaniafontanella@terra.com.br }\end{array}$ \\
\hline & $\begin{array}{l}\text { Revista da ABENO } \\
\text { http://revabeno.emnuvens.com.br/ }\end{array}$ \\
\hline \multirow{8}{*}{$\begin{array}{l}\text { Editor } \\
28-09-2016 \text { 10:18 }\end{array}$} & Assunto: [Rev ABENO] Decisão editorial \\
\hline & Prezados Autores \\
\hline & $\begin{array}{l}\text { Envio os pareceres, que não foram incluídos na mensagem anterior. } \\
\text { Atenciosamente }\end{array}$ \\
\hline & $\begin{array}{l}\text { Vania Fontanella } \\
\text { vaniafontanella@terra.com.br }\end{array}$ \\
\hline & $\begin{array}{l}\text { Avaliador A } \\
\text { It is an important article, but there is a previous article not cited an important too, because } \\
\text { changes some affirmation of the text: } \\
\text { Espejo-Trung LC, Elian SN, Luz MA. Development and Application of a New Learning } \\
\text { Object for Teaching Operative Dentistry Using Augmented Reality. J Dent Educ. } 2015 \\
\text { Nov; } 79(11): 1356-62 \text {. }\end{array}$ \\
\hline & \multirow[b]{2}{*}{$\begin{array}{l}\text { Avaliador B } \\
\text { This article requires minor changes for publication. Regarding the overall manuscript, I } \\
\text { suggest few modifications as following below: } \\
\text { Abstract } \\
\text { I suggest replace "image acquisition" for Image acquired because the images were already } \\
\text { taken. } \\
\text { Material and Method } \\
\text { As mentioned above I suggest replace "image acquisition", in the first step, for: Import or } \\
\text { access previously acquired image. } \\
\text { I suggest replace the word "construction" in the sentence "construction of the augmented } \\
\text { reality project" for create the augmented reality project. } \\
\text { Discussion } \\
\text { In the fourth paragraph of the discussion, the authors discussed about some parameters for } \\
\text { each step. Regarding to the CBCT parameters, I suggest you also give more details about the } \\
\text { "appropriate" parameters for the CBCT images. May even suggest some "ideal" protocols for } \\
\text { create 3D models with better quality. }\end{array}$} \\
\hline & \\
\hline & $\begin{array}{l}\text { Revista da ABENO } \\
\text { http://revabeno.emnuvens.com.br/ }\end{array}$ \\
\hline \multirow[t]{5}{*}{$\begin{array}{l}\text { Autor } \\
\text { 30-09-2016 11:58 }\end{array}$} & $\begin{array}{l}\text { Assunto: Augmented reality as a new perspective in dentistry: development of a } \\
\text { complementary tool. }\end{array}$ \\
\hline & Dear Prof. Vânia Fontanella, \\
\hline & $\begin{array}{l}\text { Thank you for the opportunity to submit the revision of our manuscript. We have revised } \\
\text { our paper "Augmented reality as a new perspective in dentistry: development a } \\
\text { complementary tool" following reviewers' suggestions. We listed the responses to all the } \\
\text { reviewers' comments, hoping that the revised manuscript could be considered for } \\
\text { publication. The documents were uploaded on the ABENO site. }\end{array}$ \\
\hline & Yours sincerely, \\
\hline & $\begin{array}{l}\text { Glaucia Nize Martins Santos (Corresponding author) } \\
\text { Correspondence Address: SQN 403, bloco O, apartamento 101, Asa Norte, Brasília, DF, } \\
\text { Brazil Zip Code: } 70835150\end{array}$ \\
\hline
\end{tabular}




\section{ANEXO 4 - TERMO DE CONSENTIMENTO LIVRE E ESCLARECIDO}

\section{Termo de Consentimento Livre e Esclarecido - TCLE (Utilização da plataforma Moodle)}

O (a) Senhor(a) está sendo convidado(a) a participar do projeto "E-learning em Diagnóstico Bucal", descrito como o desenvolvimento de módulos online de Radiologia Oral e conteúdos de Realidade Aumentada a fim de avaliar o impacto de novas tecnologias no ensino da disciplina. Esse projeto será desenvolvido sob a responsabilidade do pesquisador responsável (Gláucia Nize Martins Santos) e de seu professor orientador (Nilce Santos de Melo).

O objetivo geral desta pesquisa é avaliar o uso da forma computacional de ensino a distância, e-learning, no tópico de 'Princípios de Interpretação Radiográfica', dentro da disciplina de Diagnóstico Bucal, como ferramenta de ensino para os alunos de graduação em Odontologia. São objetivos específicos desenvolver material instrucional de e-learning em Radiologia Odontológica para que os alunos possam acessar a qualquer tempo e em qualquer lugar, ilimitadamente, durante o semestre letivo; aplicar o material instrucional de e-learning em Radiologia Odontológica para estudantes de graduação em Odontologia; utilizar a Realidade Aumentada como ferramenta de apoio ao ensino de Diagnóstico Bucal associada ao material instrucional de e-learning em Radiologia Odontológica; avaliar se a Realidade Aumentada é uma ferramenta eficaz no ensino de Radiologia Odontológica; avaliar o aprendizado dos estudantes utilizando e-learning, no tópico de 'Princípios de Interpretação Radiográfica', dentro da disciplina de Diagnóstico Bucal e avaliar o interesse dos alunos quanto ao uso de novas tecnologias para educação em Radiologia Odontológica.

Os participantes desse estudo serão os alunos do $4^{\circ}$ semestre do curso de Odontologia da Universidade de Brasília, matriculados na disciplina de Diagnóstico Bucal, no segundo semestre de 2015. O conteúdo de 'Princípios de Interpretação Radiográfica' será transmitido a todos os alunos da disciplina de Diagnóstico Bucal de forma presencial. O material instrucional online de e-learning será oferecido a todos os alunos da turma, sob aceitação voluntária, sendo utilizados diversos tipos de materiais didáticos interativos (Realidade Aumentada, imagens, textos para leitura na Web, aulas, exercícios, etc). Os participantes de pesquisa matriculados na disciplina "Diagnóstico Bucal" ( $4^{\circ}$ semestre) serão submetidos a testes (pré-teste e pós-teste) e 
a um questionário de satisfação. Todos os testes serão aplicados pelos professores responsáveis pela disciplina de Diagnóstico Bucal. A referida pesquisa não trará nenhum desconforto ou custo para você, e está vinculada à disciplina de Diagnóstico Bucal, do curso de graduação em Odontologia pela Universidade de Brasília a ser realizada no $2^{\circ}$ semestre de 2015, com o tempo estimado de um semestre letivo para sua realização (de setembro a dezembro de 2015). É necessário enfatizar que a sua participação na pesquisa não terá influência sobre sua nota final na disciplina. Informamos que o(a) senhor(a) pode se recusar a responder (ou participar de qualquer procedimento) qualquer questão que lhe traga constrangimento, podendo desistir de participar da pesquisa em qualquer momento sem nenhum prejuízo para o(a) senhor(a). Sua participação é voluntária, isto é, não há pagamento por sua colaboração. A pesquisadora Glaucia Nize Martins Santos oferece garantia de ressarcimento e cobertura de despesas tidas pelos participantes da pesquisa e dela decorrentes, bem como garantia de indenização diante de eventuais danos decorrentes da pesquisa. Não se exige do participante da pesquisa, sob qualquer argumento, renúncia ao direito à indenização por dano. $\mathrm{O}$ (a) senhor(a) receberá todos os esclarecimentos necessários antes e no decorrer da pesquisa e lhe asseguramos que seu nome não aparecerá, sendo mantido o mais rigoroso sigilo através da omissão total de quaisquer informações que permitam identificá-lo(a).

Há o risco de não adaptação dos alunos ao modo online de aprendizado, com possibilidade de evasão de participantes ao longo do módulo online. Para que esse risco seja minimizado, busca-se oferecer uma plataforma de aprendizado dinâmica, fácil e interativa. Cita-se como benefícios a ampliação dos conhecimentos na área de Diagnóstico Bucal, a melhora da habilidade do aluno no uso de novas tecnologias para o aprendizado e ainda a possibilidade torná-lo o sujeito ativo do aprendizado.

Os resultados da pesquisa serão divulgados na Instituição Universidade de Brasília, podendo ser publicados posteriormente. Os dados e materiais utilizados na pesquisa ficarão sob a guarda do pesquisador por um período de no mínimo cinco anos, após isso serão destruídos ou mantidos na instituição.

Se o(a) Senhor(a) tiver qualquer dúvida em relação à pesquisa, por favor telefone para: Glaucia Nize Martins Santos (pesquisadora), telefone celular 9113-8119, email nize.gal@gmail.com, ou Nilce Santos de Melo (professora orientadora), telefone celular: 91765276, e-mail nilcesantosmelo@gmail.com, ou ainda para a instituição Hospital Universitário 
de Brasília, telefone: (61) 2028-5263, no horário de 14:00 às 18:00 horas, de segunda a sextafeira.

Este projeto foi Aprovado pelo Comitê de Ética em Pesquisa da Faculdade de Ciências da Saúde (CEP/FS) da Universidade de Brasília. O CEP é composto por profissionais de diferentes áreas cuja função é defender os interesses dos participantes da pesquisa em sua integridade e dignidade e contribuir no desenvolvimento da pesquisa dentro de padrões éticos. As dúvidas com relação à assinatura do TCLE ou aos direitos do participante da pesquisa podem ser obtidos através do telefone: (61) 3107-1947 ou do e-mail cepfs@unb.br ou cepfsunb@gmail.com, horário de atendimento de 10:00hs às 12:00hs e de 13:30hs às 15:30hs, de segunda a sexta-feira.

Este documento foi elaborado em duas vias, uma ficará com o pesquisador responsável e a outra com o Senhor(a). Todas as folhas do TCLE deverão ser rubricadas pelo(a) senhor(a) ou responsável e pelo pesquisador responsável.

\section{Nome / assinatura}

Pesquisadora Responsável

Glaucia Nize Martins Santos

Brasília, de de 


\section{ANEXO 5 - TERMO DE CONSENTIMENTO LIVRE E ESCLARECIDO}

\section{Termo de Consentimento Livre e Esclarecido - TCLE (Para participação via WhatsApp)}

O (a) Senhor(a) está sendo convidado(a) a participar do projeto "E-learning em Diagnóstico Bucal", descrito como o desenvolvimento de módulos online de Radiologia Oral a fim de avaliar o impacto de novas tecnologias no ensino da disciplina. Esse projeto será desenvolvido sob a responsabilidade do pesquisador responsável (Gláucia Nize Martins Santos) e de seu professor orientador (Nilce Santos de Melo).

O objetivo geral desta pesquisa é avaliar o uso de formas tecnológicas de ensino a distância, e-learning, no tópico de 'Princípios de Interpretação Radiográfica', dentro da disciplina de Diagnóstico Bucal, como ferramenta de ensino para os alunos de graduação em Odontologia. São objetivos específicos desenvolver material instrucional de e-learning em Radiologia Odontológica para que os alunos possam acessar a qualquer tempo e em qualquer lugar, ilimitadamente, durante o semestre letivo; aplicar o material instrucional de e-learning em Radiologia Odontológica para estudantes de graduação em Odontologia; avaliar o aprendizado dos estudantes utilizando e-learning, no tópico de 'Princípios de Interpretação Radiográfica', dentro da disciplina de Diagnóstico Bucal e avaliar o interesse dos alunos quanto ao uso de novas tecnologias para educação em Radiologia Odontológica.

Os participantes desse estudo serão os alunos do $4^{\circ}$ semestre do curso de Odontologia da Universidade de Brasília, matriculados na disciplina de Diagnóstico Bucal, no primeiro semestre de 2016. O conteúdo de 'Princípios de Interpretação Radiográfica' será transmitido a todos os alunos da disciplina de Diagnóstico Bucal de forma presencial. O material instrucional online de e-learning será oferecido a todos os alunos da turma, sob aceitação voluntária, sendo utilizados diversos tipos de materiais didáticos interativos (imagens, textos, exercícios, etc) via aplicativo de celular WhatsApp. É proibida a veiculação das imagens radiográficas utilizadas ao longo do semestre fora do ambiente educacional, sob pena de quebra de sigilo do paciente.

Os participantes de pesquisa matriculados na disciplina "Diagnóstico Bucal" $\left(4^{\circ}\right.$ semestre) serão submetidos a um questionário de satisfação, que será aplicado pelos professores responsáveis pela disciplina de Diagnóstico Bucal. A referida pesquisa não trará nenhum desconforto ou custo para você, e está vinculada à disciplina de Diagnóstico Bucal, do curso de 
graduação em Odontologia pela Universidade de Brasília a ser realizada no $1^{\text {o }}$ semestre de 2016, com o tempo estimado de um semestre letivo para sua realização (de março a junho de 2016). É necessário enfatizar que a sua participação na pesquisa não terá influência sobre sua nota final na disciplina. Informamos que o(a) senhor(a) pode se recusar a responder (ou participar de qualquer procedimento) qualquer questão que lhe traga constrangimento, podendo desistir de participar da pesquisa em qualquer momento sem nenhum prejuízo para o(a) senhor(a). Sua participação é voluntária, isto é, não há pagamento por sua colaboração. A pesquisadora Glaucia Nize Martins Santos oferece garantia de ressarcimento e cobertura de despesas tidas pelos participantes da pesquisa e dela decorrentes, bem como garantia de indenização diante de eventuais danos decorrentes da pesquisa. Não se exige do participante da pesquisa, sob qualquer argumento, renúncia ao direito à indenização por dano. $\mathrm{O}$ (a) senhor(a) receberá todos os esclarecimentos necessários antes e no decorrer da pesquisa e lhe asseguramos que seu nome não aparecerá, sendo mantido o mais rigoroso sigilo através da omissão total de quaisquer informações que permitam identificá-lo(a).

Há o risco de não adaptação dos alunos ao modo online de aprendizado, com possibilidade de evasão de participantes ao longo do módulo online. Para que esse risco seja minimizado, busca-se oferecer uma plataforma de aprendizado dinâmica, fácil e interativa. Cita-se como benefícios a ampliação dos conhecimentos na área de Diagnóstico Bucal, a melhora da habilidade do aluno no uso de novas tecnologias para o aprendizado e ainda a possibilidade torná-lo o sujeito ativo do aprendizado.

Os resultados da pesquisa serão divulgados na Instituição Universidade de Brasília, podendo ser publicados posteriormente. Os dados e materiais utilizados na pesquisa ficarão sob a guarda do pesquisador por um período de no mínimo cinco anos, após isso serão destruídos ou mantidos na instituição.

Se o(a) Senhor(a) tiver qualquer dúvida em relação à pesquisa, por favor telefone para: Glaucia Nize Martins Santos (pesquisadora), telefone celular 9113-8119, email nize.gal@gmail.com, ou Nilce Santos de Melo (professora orientadora), telefone celular: 91765276, e-mail nilcesantosmelo@gmail.com, ou ainda para a instituição Hospital Universitário de Brasília, telefone: (61) 2028-5263, no horário de 14:00 às 18:00 horas, de segunda a sextafeira.

Este projeto foi Aprovado pelo Comitê de Ética em Pesquisa da Faculdade de Ciências da Saúde (CEP/FS) da Universidade de Brasília. O CEP é composto por profissionais de 
diferentes áreas cuja função é defender os interesses dos participantes da pesquisa em sua integridade e dignidade e contribuir no desenvolvimento da pesquisa dentro de padrões éticos. As dúvidas com relação à assinatura do TCLE ou aos direitos do participante da pesquisa podem ser obtidos através do telefone: (61) 3107-1947 ou do e-mail cepfs@unb.br ou cepfsunb@gmail.com, horário de atendimento de 10:00hs às 12:00hs e de 13:30hs às 15:30hs, de segunda a sexta-feira.

Este documento foi elaborado em duas vias, uma ficará com o pesquisador responsável e a outra com o Senhor(a). Todas as folhas do TCLE deverão ser rubricadas pelo(a) senhor(a) ou responsável e pelo pesquisador responsável.

Nome / assinatura

Telefone celular (WhatsApp)

Pesquisadora Responsável

Glaucia Nize Martins Santos

Brasília, de março de 2016. 